\title{
МОЛОАТЖА HAYKOBA
}

AITА

\section{МАТЕРІАЛИ МЖЖНАРОДНОӦ СТУДЕНТСЬКОÏ НАУКОВОÏ КОНФЕРЕНЦIÏ}

\section{9 ТРАВНЯ 2020}

М. ЛЬВІВ, УКРАÏHA

МОДЕРНІЗАЦІЯ ТА СУЧАСНІ УКРАÏНСЬКІ ТА СВІТОВІ НАУКОВІ ДОСЛІДЖЕННЯ 


\section{МОАОАХКА HAYKOBA AIIA}

МАТЕРІАЛИ МІЖНАРОДНОЇ СТУДЕНТСЬКОÏ НАУКОВОÏ КОНФЕРЕНЦІї

29 ТРАВНЯ 2020

М. ЛЬВІВ, УКРАЇНА

МОДЕРНІЗАЦІЯ ТА СУЧАСНІ УКРАÏНСЬKI ТА СВITOBI НАУКОВІ ДОСЛІДЖЕННЯ TOM 2 
Голова оргкомітету: Коренюк I.O.

Верстка: Дудник Г.М.

Дизайн: Бондаренко I.B.

\section{74 Модернізація та сучасні українські та світові наукові дослідження: матеріали міжнародної студентської наукової конфреренції (Т. 2), 29 травня, 2020 рік. Львів, Україна: Молодіжна наукова ліга.}

\section{ISBN 978-617-7171-76-7}

DOI 10.36074/29.05.2020.v2

Викладено матеріали учасників міжнародної мультидисциплінарної наукової консреренції «Модернізація та сучасні українські та світові наукові дослідження», яка відбулася у місті Львів 29 травня 2020 року.

Конференцію зареєстровано Державною науковою установою «УкрIHTEl» в базі даних науково-технічних заходів України та інформаційному бюлетені «План проведення наукових, науково-технічних заходів в Україні» (Посвідчення № 269 від 19.03.2020).

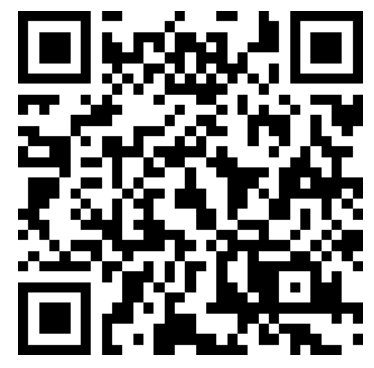

Матеріали конфреренції знаходяться у відкритому доступі на умовах ліцензії Creative Commons Attribution 4.0 International (CC BY 4.0).

Всі роботи збірника, що містять DOI індексуються в Google Scholar, ORCID, CrossRef ma OUCl (Український індекс наукового цитування). 


\section{MICT}

\section{СЕКЦІЯ 2.}

\section{ТЕХНІЧНІ НАУКИ ТА ІНФОРМАЦЙНІ ТЕХНОЛОГІЇ}

NOSQL БАЗИ ДАНИХ ТА ORM ДЛЯ РОБОТИ 3 НИМИ

Бондаренко М.В.

АВТОМАТИЗОВАНА СИСТЕМА ОЦІНКИ ЗНАНЬ СТУДЕНТІВ

Кобзар В.В.

АНАЛІЗ ТА РОЗРОБКА КОМПОНЕНТІВ ІНФОРМАЦІЙНОЇ СИСТЕМИ ДЛЯ ВИВЧЕННЯ ІНОЗЕМНОЇ МОВИ

Бойко В.I.

ВИКОРИСТАННЯ МОЛОЧНОЇ СИРОВИНИ ДЛЯ РОЗРОБКИ РЕЦЕПТУРИ М' ЯСНИХ НАПІВФАБРИКАТІВ

Шевченко І.Ю.

ВИКОРИСТАННЯ КОНЦЕПЦІЇ НЕВИЗНАЧЕНОСТІ ПРИ ВИМІРЮВАННІ ВИТРАТИ РЕЧОВИНИ

Іброхімова А.А.

ЖИРОВІ МАСИ У КОНДИТЕРСЬКІЙ ПРОМИСЛОВОСТІ ТА ОСОБЛИВОСТІ РОБОТИ ОБЛАДНАННЯ ДЛЯ ЇХ ПЛАВЛЕННЯ В ТЕХНОЛОГІЧНИХ ПРОЦЕСАХ ПЕРЕРОБКИ

Лопатко Ю.М.

ЗОВНІШНЕ НЕЗАЛЕЖНЕ ОЦІНЮВАННЯ ЯКОСТІ ОСВІТИ В УКРАЇНІ: ПРОГРАМИ ДЛЯ ПІДГОТОВКИ ТА ПРОХОДЖЕННЯ

Безруков О.О.

ІДЕНТИФІКАЦІЯ ОБ'ЄКТА ТА СИНТЕЗ САР ТЕХНОЛОГІЧНИМ ПРОЦЕСОМ ПАСТЕРИЗАЦІЇ

Михайлов М.А.

МЕТОДИ АНАЛІЗУ МЕДІАКОНТЕНТУ В ІНФОРМАЦІЙНО-АНАЛІТИЧНИХ СИСТЕМАХ

Лазарєв Я.О.

ОСОБЛИВОСТІ І ПРОБЛЕМИ ДИСТАНЦІЙНОГО НАВЧАННЯ

Галагура К.А.

ПЕРЕВАГИ ЗАСТОСУВАННЯ МІКРОСЕРВІСНОЇ АРХІТЕКТУРИ ПРИ ПОБУДОВІ РОЗПОДІЛЕНИХ СИСТЕМ

Малітчук А.Д.

ПРОГРАМУВАННЯ ДРОНІВ НА ОСНОВІ НЕЙРОННИХ МЕРЕЖ ДЛЯ ВИЯВЛЕННЯ ПОЖЕЖ НА РАННІЙ СТАДІЇ

Козловський П.-В. Ю.

РОЗРОБКА ПРОГРАМНОГО ЗАБЕЗПЕЧЕННЯ РОЗБИТТЯ ЗОБРАЖЕННЯ НА ФРАГМЕНТИ ЗАСОБАМИ КОНТУРНОГО АНАЛІЗУ

Голтвянська К.О. 
РОЗРОБКА ІНТЕРАКТИВНИХ ВЕБ-ДОДАТКІВ

Лічман Е.P. .36

РОЗРОБКА РЕГУЛЯТОРА НАЛАШТУВАННЯ КОТУШКИ В РЕЗОНАНС 3 ЄМНІСТЮ МЕРЕЖІ НА БАЗІ МІКРОПРОЦЕСОРА

Мараренко В.O.

СРАВНЕНИЕ МЕТОДОВ СТЕГАНОГРАФИИ В ИЗОБРАЖЕНИЯХ

Самойленко Е.А., Шморгай Е.О.

СУЧАСНІ СИСТЕМИ УПРАВЛІННЯ НАВЧАННЯМ

Сорока С.Ю.

УДОСКОНАЛЕННЯ ТЕХНОЛОГІЇ «SOUS VIDE» ДЛЯ ПРОДУКТІВ 3 М'ЯСА ПТИЦІ

Дьяченко Є.B.

ФОРМИРОВАНИЕ БЕТОННОЙ СМЕСИ С ИСПОЛЬЗОВАНИЕМ СТЕКЛОБОЯ

Карбаев К.К.

ЦИФРОВА СИСТЕМА УПРАВЛІННЯ КУТОВИМІРЮЮЧИМ ПРИСТРОЕМ НАВІГАЦІЙНОГО КОМПЛЕКСУ

Кішка Б.В.

\section{СЕКЦІЯ 3.}

\section{ФІЗИКО-МАТЕМАТИЧНІ НАУКИ}

ЗАСТОСУВАННЯ НЕЙРОННИХ МЕРЕЖ ДЛЯ АПРОКСИМАЦІЇ ФУНКЦЙ Костенко О.В., Ракіта Н.Є.

НЕІТЕРАЦІЙНІ МЕТОДИ ЗВЕДЕННЯ ЗВИЧАЙНИХ ДИФЕРЕНЦІАЛЬНИХ РІВНЯНЬ 3 КРАЙОВИМИ УМОВАМИ ДО ЗАДАЧ КОШІ

Дмітрова К.М.

СИСТЕМИ МАСОВОГО ОБСЛУГОВУВАННЯ В ХОСТИНГОВИХ КОМПАНІЯХ Дженкова М.М.

\section{СЕКЦІЯ 4.}

ХІМІЧНІ НАУКИ

ДИКОМПОНЕНТНІ СУМІШІ 3 N-КАРБОНІЛВМІСНИМИ ГРУПУВАННЯМИ Краснопір М.М.

\section{СЕКЦІЯ 5.}

\section{БІОЛОГІЧНІ НАУКИ}

ВРЕДИТЕЛИ И БОЛЕЗНИ АКТИНИДИИ (КИВИ)

Одінцова М.О.

ЕХІНОКОКОЗ ЯК ГОСТРО ПАРАЗИТУЮЧА ХВОРОБА ЛЮДЕЙ І ТВАРИН

Іванова А.O. 


\section{СЕКЦІЯ 6.}

\section{МЕДИЧНІ НАУКИ}

АНАЛІЗ ДИНАМІКИ ЗАХВОРЮВАНОСТІ НА НОВІ ВИПАДКИ ТА РЕЦИДИВИ ТУБЕРКУЛЬОЗУ У ХАРКІВСЬКІЙ ОБЛАСТІ ЗА 5 РОКІВ

Лісова С.М., Шарун С.Н.

ВИБІР ПОЧАТКОВОЇ АНТИГІПЕРТЕНЗИВНОЇ ТЕРАПІЇ У ПАЦІЕНТІВ 3 АГ 1СТУПЕНЯ

Аксенкова С.M.

ВИВЧЕННЯ РІВНЯ ОБІЗНАНОСТІ СТУДЕНТІВ ВИЩИХ НАВЧАЛЬНИХ ЗАКЛАДІВ УКРАЇНИ ЩОДО ПРОФІЛАКТИКИ, ШЛЯХІВ ПЕРЕДАЧІ ТА ЛІКУВАННЯ ВІЛ-ІНФЕКЦІЇ ТА ОЦІНКА СТИГМИ ЩОДО ВІЛ-ІНФІКОВАНОГО НАСЕЛЕННЯ

Мимренко А.A. 66

ВИВЧЕННЯ ЕПІДЕМІЧНИХ ПАРАМЕТРІВ РОЗПОВСЮДЖЕННЯ ТУБЕРКУЛЬОЗУ ТА ЙОГО ПРОФІЛАКТИКИ

Стоян А.О., Колесник М.P.

ВИНИКНЕННЯ ІНФЕКЦІЙНИХ ОСЕРЕДКІВ У ПОБУТІ

Матрьонін A.P.

ВПЛИВ КАРАНТИНУ НА ЗМІНУ БІОЛОГІЧНОГО РИТМУ СТУДЕНТІВ

Хомякова В.С., Мкртчян А.А.

ВПЛИВ ТРАНС-IЗОМЕРІВ ЖИРНИХ КИСЛОТ НА ОРГАНІЗМ ЛЮДИНИ

Немеш B.I.

ДОЦІЛЬНІСТЬ ВИКОРИСТАННЯ БЦЖ В УКАЇНІ

Якушев С. Д., Кікош К.Ю.

ЗАЛЕЖНІСТЬ ПІСЛЯОПЕРАЦЙНИХ ГОРМОНАЛЬНИХ УСКЛАДНЕНЬ ВІД ОБ'ЄМУ ОПЕРАТИВНОГО ВТРУЧАННЯ НА ЩИТОПОДІБНІЙ ЗАЛОЗІ ТА МЕТОДИ ЇХ КОРЕКЦІЇ

Лещук I.B.

МЕДИЧНІ ВІДХОДИ: ПРОБЛЕМИ ТА МЕТОДИ УТИЛІЗАЦІЇ

Мареніч Г.Г., Явтушенко А.С.

МЕТОДИ ДІАГНОСТИКИ ТЯЖКОЇ ІНТУБАЦІЇ ТРАХЕЇ У ПАЦІЕНТІВ 3 ОЖИРІННЯМ

Глущенко I.I., Некрасова Н.М.

ПРОБЛЕМИ РЕПРОДУКТИВНОЇ ФУНКЦІї ЖІНОК

Савченко Д.М.

РОЛЬ ДЕЯКИХ БІОХІМІЧНИХ РЕАКЦІЙ В ОРГАНІЗМІ ЛЮДИНИ

Кузьмак М.В.

РОЛЬ БАРІАТРИЧНОЇ ХІРУРГІЇ В ЛІКУВАННІ НЕАЛКОГОЛЬНИХ ЖИРОВИХ ЗАХВОРЮВАНЬ ПЕЧІНКИ

Колесник М.P. 88 


\section{СЕКЦІЯ 7.}

\section{ПСИХОЛОГІЧНІ ТА СОЦІОЛОГІЧНІ НАУКИ}

ВПЛИВ МОТИВАЦІЇ НА ПРОКРАСТИНАЦІЮ У СТУДЕНТІВ

Червінко Л.М.

ДІАГНОСТИЧНІ МЕТОДИ В РОБОТІ СОЦІАЛЬНОГО ПРАЦІВНИКА

Василик О.М.

ІНФОРМАЦІЙНО-КОМУНІКАЦЙНІ ТЕХНОЛОГІЇ В ОСВІТІ ДОРОСЛИХ

Костіна А.C.

ОСОБЛИВОСТІ СОЦІАЛЬНО - ПСИХОЛОГІЧНОЇ АДАПТАЦІЇ ДІТЕЙ СТАРШОГО ДОШКІЛЬНОГО ВІКУ З ВИСОКИМ РІВНЕМ ТРИВОЖНОСТІ

Кулик Г.В.

ПСИХОЛОГИЧЕСКИЕ ПРЕПЯТСТВИЯ ДЛЯ ОСУЩЕСТВЛЕНИЯ ПЕРЕМЕН

Шморгай E.O. 100

РАЗВИТИЕ ВЗРОСЛЫХ В ВИРТУАЛЬНОМ ИНТЕЛЛЕКТУАЛЬНООБРАЗОВАТЕЛЬНОМ ПРОСТРАНСТВЕ

Шморгай Е.О., Вракина К.П. 102

РОЛЬ ЕМОЦІЙНОГО ІНТЕЛЕКТУ В РЕГУЛЯЦІЇ ЖИТТЯ ЛЮДЕЙ 3 АДИКТИВНОЮ ПОВЕДІНКОЮ

Ричков С.B. 104

РОЛЬ СПІЛКУВАННЯ У ПСИХОЛОГІНОМУ РОЗВИТКУ ЛЮДИНИ

Сорохан К.A.

СХИЛЬНІСТЬ ДО МАНІПУЛЯЦІї У СПІЛКУВАННІ СЕРЕД МОЛОДІ

Меняйлова М.I.

ТЕХНОЛОГІЯ СТВОРЕННЯ ШКІЛЬНОЇ СЛУЖБИ ПОРОЗУМІННЯ “СОNТАСТ” В ГЕРОНИМІВСЬКОМУ ЗАКЛАДІ ЗАГАЛЬНОЇ СЕРЕДНЬОЇ ОСВІТИ І-ІІІ СТУПЕНІВ

Штангрет Л.І. 


\section{СЕКЦІЯ 2. ТЕХНІЧНІ НАУКИ ТА ІНФОРМАЦЙНІ ТЕХНОЛОГЇ}

Бондаренко Михайло Володимирович, здобувач вищої освіти приладобудівного факультету Начіональний технічний університет Украӥни «Київський політехнічний інститут імені Ігоря Сікорського», Україна

\section{NOSQL БАЗИ ДАНИХ ТА ОRМ ДЛЯ РОБОТИ 3 НИМИ}

В останні часи набувають досить високої популярності так звані NoSQL бази даних вони забезпечують механізм зберігання та пошуку даних, який моделюється іншими засобами, ніж табличні відносини, використовувані в реляційних базах даних. Бази даних NoSQL все частіше використовуються у великих додатках даних та веб-додатках у режимі реального часу.

Системи які входять до числа NoSQL баз даних досить різноманітні, кожна з яких надає свій список унікальних особливостей. Але, не дивлячись на їх різноманітність, можливо виділити чотири основних типи сховищ:

- Ключ-значення: Redis;

- Документ: MongoDB, CouchDB;

- 3 широким стовпчиком: Cassandra, HBase;

- Графові: Neo4j.

Ключ-значення сховища використовують асоціативні масиви у якості фундаментальної моделі даних. Вони являються найпростішими і можуть зберігати лише пари ключів та значень, а також вилучати значення за відомим ключем. Вважається, що такі системи не підходять для використання в складних системах, але в той же час їх простота та ефективність збереження даних дозволяє використовувати їх у якості високопродуктивних баз даних [1].

Документ сховища, також називаються документно-орієнтовані бази даних, характеризуються організацією даних за відсутності схеми. А це в означає, що записи не повинні мати єдину структуру, що в свою чергу дає можливість мати записи з різною кількістю полів, різними типами даних, а також мати вкладені структури, по типу масивів чи списків [2].

Сховища 3 широким стовпчиком, також називаються розширюваними сховищами записів, на відміну від реляційних баз даних, мають можливість зберігати в собі велике число динамічних стовпців. Так як назви стовпців та ключів не фіксовані, тобто їх можливо змінити, такі бази даних можливо розглядати як двовимірне ключ-значення сховище. Найбільша перевага таких систем полягає у надзвичайно швидкому виконанні агрегатних функції [3].

Графові бази даних представляють дані структурою графів за допомогою вузлів та ребер, що являються зв'язками між вузлами. В такій формі доволі легко обробляти з даними та виконувати прості підрахунки над ними. Недоліком же являється факт того, що графові бази даних зазвичай не надають можливості індексації по всім вершинам, що впливає на час доступу до конкретних даних [4].

Порівняльна характеристика згаданих типів представлена в (табл. 1): 
Співставлення основних показників різних типів баз даних

Таблиия 1

\begin{tabular}{|c|c|c|c|c|c|}
\hline Тип & Продуктивність & Масштабованість & Гнучкість & Складність & Функціональність \\
\hline $\begin{array}{c}\text { Ключ- } \\
\text { зачення }\end{array}$ & Висока & Висока & Висока & Ніякої & Варіюється \\
\hline Документ & Висока & Висока & Висока & Низька & Варіюється \\
\hline $\begin{array}{c}\text { З широким } \\
\text { стовпчиком }\end{array}$ & Висока & Висока & Помірна & Низька & Мінімальна \\
\hline Графові & Перемінна & Перемінна & Висока & Висока & Теорія графів \\
\hline Реляційні & Перемінна & Перемінна & Низька & Помірна & Реляційна алгебра \\
\hline
\end{tabular}

дані сформовано з [5]

Як можливо помітити NoSQL бази даних надають кращу продуктивність порівняно зі звичайними реляційними базами даних, що зменшує час необхідний на виконання запитів і операцій з даними. Суттєвою перевагою також являється можливість масштабування, при чому масштабування не тільки вертикальне, коли збільшуються виділені ресурси для бази даних (оперативна пам'ять, кількість ядер процесору), а саме горизонтальне масштабування, яке проводиться шляхом додання нових вузлів (буквально, додання серверу с базою даних). Реляційні бази даних, нажаль, майже не масштабуються горизонтально і можливість проведення такої процедури наявна лише у деяких [6].

Складність, буквально, можливо розглядати як поріг входу який необхідно здолати, щоб повністю зрозуміти структуру бази даних та мати можливість адекватно іï використовувати. I аналіз показує, що NoSQL бази даних мають доволі низькі вимогу для вивчення. Окрім графових, але функціонал які вони надають повністю виправдовує складність.

В (табл. 2) наведена підтримка функціоналу, як вторинних індексів, операцій MapReduce та запитів, в конкретних постачальниках NoSQL баз даних:

Таблиия 2

Підтримка функціоналу вторинних індексів, операцій MapReduce та запитів у NoSQL базах даних

\begin{tabular}{|c|c|c|c|}
\hline База даних & Вторинні індекси & MapReduce [7] & Запити \\
\hline MongoDB & Підтримується & JavaScript & Повні, з јоin-ами \\
\hline Cassandra & Підтримується & Hе підтримується & СQL (без јоin-ів) \\
\hline HBase & Не підтримується & Hadoop & Слабка підтримка \\
\hline CouchDB & Підтримується & JavaScript & Підтримка view \\
\hline Neo4j & Підтримується & Не підтримується & $\begin{array}{c}\text { Пошук та графові } \\
\text { операції }\end{array}$ \\
\hline
\end{tabular}

дані сформовано з [8]

Помітно, що вторинні індекси підтримують переважні більшість, а це означає, що оптимізацію запитів можливо провести по спеціальній колонці, а не тільки по первинному ключу. Окрім цього також наявна підтримка операції MapReduce, котра хоча і являється дещо вузько направленою і використовується переважно в області роботи з великими об'ємами даних, все ж таки суттєво спрощує обробку даних, а тому підтримка подібного функціоналу невідмінно являється перевагою.

Окремо слід відзначити можливість виконувати SQL-подібні запити. Хоча сама структура NoSQL баз даних фундаментально відрізняється від реляційних, іноді все ж таки постає необхідність виконати щось подібне на SQL запит. MongoDB надає повну підтримку, навіть дозволяє використовувати јоin-и. Cassandra зі своїм CQL (Cassandra Query Language) підтримує усі операції окрім јоin-ів, обумовлено це особливостями структури баз даних з широким стовпчиком.

Усе це чудово, NoSQL бази даних виглядають доволі привабливо, однак самі по собі бази даних рідко використовуються, здебільшого вони використовуються при розробці 
яких-небудь додатків на певній мові програмування. Тому постає питання перетворення даних з бази даних у об'єкти мови розробки. Цю задачу вирішують ORM технології.

Одним з найбільш поширених ORM для Cassandra являється DataStax Java Driver, він надає можливості асинхронного виконання запитів [9], підтримує CQL 3 [10], дозволяє виконувати CRUD операції. Звісно ж DataStax не єдиний ORM, однак історія так склалася, що він найбільш стабільний і підтримується командою розробників, а інші, наприклад Hector, Astyanax, Pelops в даний час являються закинутими проектами і більше не розробляються, хоча їх досі можливо використовувати для попередніх версій Cassandra, від 1.0 до 2.0.

У світі MongoDB справи виглядають значно краще, так як сам MongoDB стабільно розвивається і постійно доповнюється новим функціоналом. Перший ORM який приходить на думку це Morphia, напевно тому що він являється першим в своєму роді. Morphia досить легко інтегрується с іншими фреймворками, як Spring, Guice, Dagger, надає можливості виконувати підготовчі операції перед витягом даних за бази даних та завершальних операцій після, а також значно спрощує написання обробки даних [11].

Не варто забувати про такого гіганта як Spring Data, котрий входить в число модулів Spring Framework. Враховуючи популярність Mongo зовсім не дивно що в Spring присутня iii підтримка у вигляді Spring Data MongoDB. Він надає можливість створення шаблонів, для пришвидшення виконання звичайних операцій, функціонал керування життєвим циклом, підтримка геопросторових запитів, можливість генерації запитів по сигнатурі методів, а також функції для створення нумерованих сторінок запитів, сортування даних та CRUD операції [12].

Звісно ж список ORM для Mongo не був би повним без Hibernate, який, по суті, являється стандартом ORM для реляційних баз даних. Hibernate OGM дещо відрізняється від попередніх ORM, так як він організовує повну підтримку JPA стандарту для NoSQL баз даних, що робить його ідеальним вибором при розробці великих комерційних проектів. Окрім цього він конвертує усі запити в нативні підвищуючи тим самим швидкість відпрацювання, використовує власний Hibernate Search для індексування, а також підтримує транзакційні операції [13]. Варто також відзначити, що Hibernate OGM та Spring Data надають підтримку для CouchDB, Neo4j та Cassandra.

Висновок. Аналіз NoSQL баз даних показує, що ця сфера являється дуже різноманітною і швидко оновлюваною. Існуючі бази даних мають кардинально різні структури та можуть використовуватися для вирішення широкого спектру задач, будь то аналіз даних в області Big Data, чи збереження повідомлень в системі онлайн чату. Кожна 3 цих баз даних являється унікальною надаючи свій список переваг. Використання ORM технологій в парі з NoSQL базами даних дозволяє суттєво розширити їх функціонал, додаючи такі можливості, як, можливість здійснювати транзакції та керування життєвим циклом обробки даних.

\section{Список використаних джерел:}

1. Key-value Stores (2013). Вилучено з https://db-engines.com/en/article/Key-value+Stores

2. Document Stores (2013). Вилучено з https://db-engines.com/en/article/Document+Stores

3. Wide Column Stores (2013). Вилучено з https://db-engines.com/en/article/Wide+Column+Stores

4. Graph DBMS (2013). Вилучено 3 https://db-engines.com/en/article/Graph+DBMS

5. Mark Drake (2019) A Comparison of NoSQL Database Management Systems and Models. Вилучено 3 https://www.digitalocean.com/community/tutorials/a-comparison-of-nosql-database-management-systems-andmodels

6. Relational Database Management System (RDBMS) vs noSQL (2015). Вилучено 3 https://www.loginradius.com/engineering/relational-database-management-system-rdbms-vs-nosql/

7. Jeffrey Dean \& Sanjay Ghemawat (2004). MapReduce: Simplified Data Processing on Large Clusters. Вилучено 3 http://static.googleusercontent.com/media/research.google.com/es/us/archive/mapreduce-osdi04.pdf

8. John Wiley (2011). Professional NoSQL. Indianapolis: John Wiley \& Sons, Inc 
9. DataStax Documentation, Asynchronous programming (2020). Вилучено 3 https://docs.datastax.com/en/developer/java-driver/4.6/manual/core/async/

10. DataStax Documentation, Query builder (2020). Вилучено 3 https://docs.datastax.com/en/developer/javadriver/4.6/manual/query_builder/

11. Morphia Quick Tour (2019). Вилучено з https://morphia.dev/1.5.8/getting-started/quick-tour/

12. Mark Pollack, Thomas Risberg, Oliver Gierke, Costin Leau, Jon Brisbin, Thomas Darimont, Christoph Strobl, Mark Paluch, Jay Bryant (2020). Spring Data MongoDB - Reference Documentation. Вилучено 3 https://docs.spring.io/spring-data/mongodb/docs/current/reference/html/\#reference

13.Emmanuel Bernard, Sanne Grinovero, Gunnar Morling, Davide D'Alto, Guillaume Scheibel, Mark Paluch, Guillaume Smet, Fabio Massimo Ercoli (2018). Hibernate OGM 5.4.1.Final: Reference Guide. Вилучено 3 https://docs.jboss.org/hibernate/stable/ogm/reference/en-US/html_single/

Кобзар Владислав Віталійович, здобувач вищої освіти приладобудівного факультету Національний технічний університет Украӥни «Київський політехнічний інститут імені Ігоря Сікорського», Украӥна

\section{АВТОМАТИЗОВАНА СИСТЕМА ОЦНКИ ЗНАНЬ СТУ ДЕНТІВ}

В Українському законодавстві під дистанційним навчанням розуміється індивідуалізований процес набуття знань, умінь, навичок і способів пізнавальної діяльності людини, який відбувається в основному за опосередкованої взаємодії віддалених один від одного учасників навчального процесу у спеціалізованому середовищі, яке функціонує на базі сучасних психолого-педагогічних та інформаційно-комунікаційних технологій [1].

До основних функцій процесу підготовки фахівців 3 вищою освітою належать створення, передавання та поширення знань, що дозволяє сформувати у студентів вміння й усвідомлення навчатися протягом усього життя.

Проблема та актуальність дистанційного оцінювання знань студентів

Проблема якісного контролю знань і підведення підсумків результатів оцінювання дистанційно до сих пір залишається актуальною, тому останнім часом в систему освіти впроваджуються автоматизовані системи оцінювання знань, що в певній мірі надають змогу отримувати освіту та контролювати якість отриманих знань дистанційно.

На різних етапах дистанційного навчання використовуються різні види контролю: попередній, поточний і підсумковий.

Попередній контроль спрямований на виявлення знань, умінь і навичок, компетенцій студентів з усіх розділів предмета, який буде вивчатися. Результати вхідного тестування дають можливість викладачеві-тьютору спланувати спільну роботу, діагностувати прогалини в знаннях, визначити, на які теми слід виділити більше часу, тобто сформувати індивідуальну освітню траєкторію студента.

Поточний контроль здійснюється в повсякденній роботі з метою перевірки засвоєння матеріалу. Поточний контроль успішності здійснюється методом самоконтролю і за допомогою тестування студентів та фіксування результатів, а також в процесі спілкування викладача-тьютора та студента. Такий контроль повинен обов'язково передувати переходу до нової теми, модулю, новому виду навчальної діяльності. Його підсумки викладачтьютор обов'язково повинен враховувати у своїй подальшій роботі. Поточний контроль у дистанційному навчанні має важливий дидактичний сенс, оскільки дає можливість адекватно оцінювати навчальні результати і вчасно коригувати помилки і прогалини в знаннях студента.

Підсумковий контроль проводиться в кінці вивчення курсу. Його завдання визначити досягнутий рівень підготовки студента. Під педагогічними методами контролю 
якості навчальної діяльності ми розуміємо способи діяльності викладача-тьютора та студентів, за допомогою яких визначається результативність навчально-пізнавальної діяльності, виявляється рівень засвоєння навчального матеріалу. Розглянемо різні методи контролю, що можуть бути застосовані в дистанційному навчанні [1].

Одним $з$ досягнень сучасної методики оцінювання при реалізації рейтингових систем вважається тестовий контроль, який допомагає більш чітко прослідковується структуру знань студентів і на підставі цього переоцінити методичні підходи до вивчення дисципліни, індивідуалізувати процес навчання, сприяти самостійній роботі. На відміну від інших завдань, тест $\epsilon$ науково-емпіричним методом дослідження, дозволяють перебороти умоглядні оцінки знань студентів і відрізняються своєю технологічністю.

Тестування застосовується в техніці, медицині, психіатрії, освіті для визначення придатності об'єкта тестування для виконання тих чи інших функцій. Якість тестування і достовірність його результатів значною мірою залежить від методів тестування та складу тесів.

Процес тестування включає:

- подачу тестового набору;

- визначення реакції об’єкта тестування на тестовий набір;

- оцінка реакції реакції об'єкта і висновки.

Тестовий набір складається $з$ окремих тестів і розробляється таким чином, щоб забезпечити повне або значне покриття множини ймовірних впливів на об'єкт тестування[2].

В педагогічній діагностиці отримали поширення методи тестування, що не погіршують якості отриманих об'єктом тестувань знань. Ця специфіка пов'язана з тим, що процес тестування $є$ частиною навчального процесу і під час тестування студент не повинен отримувати або закріплювати хибних знань.

Тестування приваблює тим, що [3]:

- ставить всіх студентів в однакові умови;

- може використовуватися, як для формального оцінювання, так і для самоконтролю під час вивчення певної теми;

- виключає суб'єктивне ставлення викладачів, оскільки викладач

- можливість автоматизації обробки результатів і практично моментальна зворотний зв'язок між студентом та навчальним матеріалом;

- містить елементи гри, що сприяє зменшенню рівню стресу.

3 позиції кібернетики процес навчання повинен бути процесом систематичного управління, що основується на інформації про хід засвоєння нових знань, що і є зворотнім зв'язком системи управління навчальним процесом [4].

Для проведення оперативного поточного контролю при дистанційному навчанні дуже зручно використовувати різноманітні анкети. Анкета $є$ достатньо гнучким інструментом, оскільки питання можна задавати безліччю різних способів. Анкета виконує два завдання. Перша - самооцінка студента своїх навчальних досягнень у відповідності до змісту матеріалу. Друга - співвіднесення самооцінки студента і його реальних результатів викладачем- тьютором. На основі отриманих даних викладачу-тьютору потрібно провести коригувальні заходи. Самоконтроль є одним з найважливіших факторів, що забезпечують самостійну пізнавальну діяльність студентів. Самоконтроль $є$ форма діяльності, що виявляється в перевірці поставленого завдання, у критичній оцінці процесу роботи, у виправленні ії недоліків [1].

Одним із ключових чинників у самоосвіті з використанням e-learning виступає мотивація до навчання. Саме тому перед вищими навчальними закладами постає важливе завдання створення навчального середовища, яке б спонукало студентів до зацікавленості в самостійному отриманні нових знань. 
Останні дослідження щодо реалізації e-learning проектів в межах системи самоосвіти України та західних країн показали, що в майбутньому необхідно, по-перше, звернути увагу на ефективне в дидактичному аспекті використання інформаційних технологій на базі системного підходу, а саме: застосування програмного забезпечення, створеного 3 урахуванням навчального змісту та орієнтованого на цілі навчання, останні досягнення педагогіки та психології [5].

\section{Висновок}

3 кожним днем все більш гостро постає питання дистанційного навчання, тому важлива наявність автоматизованих систем оцінки знань, які в повній мірі зможуть оцінити знання студентів. У статті були розглянуті основні типи та види оцінювання студентів на які варто звернути увагу при проектувані та розробці системи автоматизованої оцінки знань студентів.

\section{Список використаних джерел:}

1. Самолюк, Н. Актуальність і проблемність дистанційного навчання / Наталія Самолюк, Микола Швець // Нова пед. думка. - 2013. - № 1.1. - С. 193-197 Електронний ресурс]. - Режим доступу: http://nbuv.ov.ua/UJRN/Npd_2013_1_50

2. Застосування системи автоматизованого опитування студентів ВНЗ[Електронний ресурс] : матеріали міжвузівського вебінару (м.Вінниця, 15 грудня 2015 р.) / відп. ред. Л.Б.Ліщинська. -Вінниця : ВТЕІ KHTEУ, 2015. $-141 \mathrm{c}$.

3. Модернізація вищої освіти України і Болонський процес: [Матеріали до першої лекції]/М.Ф. Степко, Я. Я.Болюбаш, К.М. Левківський та ін. -: НМЦ вищої освіти МОН України, 2004. - 24 с.

4. Автоматизоване керування навчанням: Методичний посібник. Під редакцією А.М. Кутєпова -М.:1991. $235 \mathrm{c}$.

5. Ноздрина Л. В. Исследование результатов e-learning проектов в высшей школе Украины / Л. В. Ноздрина. [Електронний ресурс]. - Режим доступу: http://ifets.ieee.org/russian/depository.

Бойко Вікторія Ігорівна, здобувач вищої освіти факультету комп'ютерні науки Харківський національний університет радіоелектроніки, Украӥна

\section{АНАЛІЗ ТА РОЗРОБКА КОМПОНЕНТІВ ІНФОРМАЦЙНОӦ СИСТЕМИ ДЛЯ ВИВЧЕННЯ ІНОЗЕМНОЇ МОВИ}

Останнім часом знання та використання іноземних мов все більше впливає на свідомість і діяльність людей. Знання мов в сьогоденні відіграє важливу роль в житті людини. I якщо декілька десятирічь тому знання мов давало людям певні перевали в особистому та професійному бутті, то сьогодні, людина, що не володіє бодай однією іноземною мовою стає дуже вразливою. На ринку праці, у більшості галузей, резюме в яких не зазначено знання іноземної мови (переважно англійської) навіть не розглядаються. Навіть якщо компанія нічим не пов'язана з зарубіжжям і робітник не буде використовувати іноземну мову в своїй безпосередній роботі, перевага буде надана кандидату, що знає іноземну мову. Адже вивчення іноземної мови розвиває пам'ять та мислення, свідчить про старанність людини, ii здатність до навчання (можливість вивчати літературні та відеографічні матеріали мовою оригіналу в цьому також допомагають) та вміння досягати цілей [1]. Окрім влаштування на роботу англійська може стати у нагоді і в особистому житті: можливість мати друзів іноземців або при подорожі, де володіючи англійському мовою людина буде почувати себе більш впевненою (знаючи, що завжди може звернутися по допомогу), дізнається багато нового від живих людей (при спілкуванні з місцевими), а не шаблонних екскурсіях. 
Зважаючи на всі ці факти, знання іноземної мови є дуже актуальною темою, але відсоток людей, що вільно володіють бодай однією - все ще дуже малий. За даними онлайн дослідження компанією TNS - лише $18 \%$ українців володіють англійською мовою на рівні вище середнього (рис. 1). Саме тому актуальним є питання методів та засобів для ефективного вивчення іноземної мови.

\section{7. СТАН ВОЛОДІННЯ ІНОЗЕМНИМИ МОВАМИ В УКРАЇНІ СЬОГОДНІ \\ "Моніторинг сприйняття реформ у суспільстві" на замовлення Національної ради реформ \\ у рамках національної програми вивченя та популярізації іноземних мов "Україна speaking"}

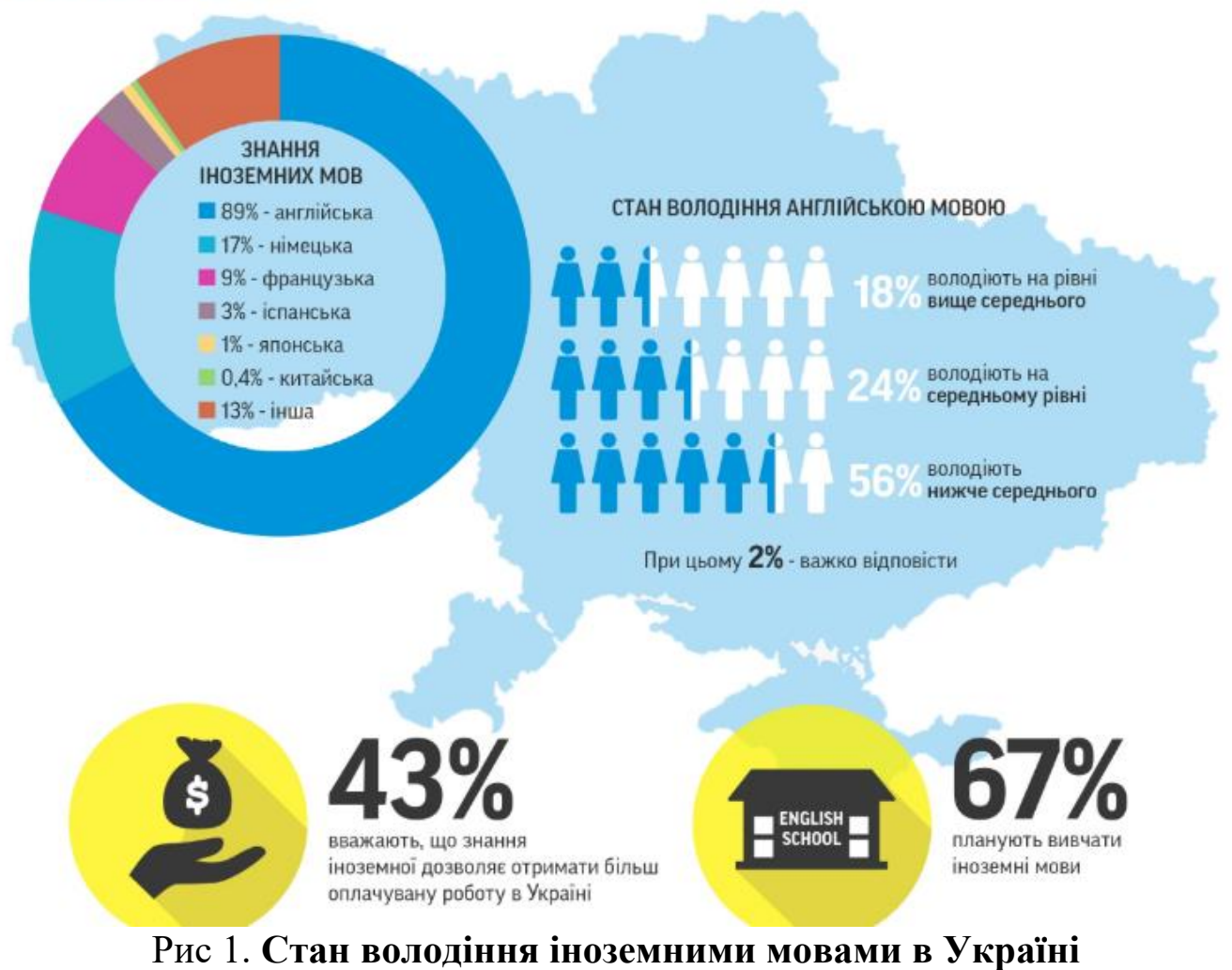

Найпопулярнішими методами вивчення іноземних мов зараз є: відвідування мовних курсів/репетиторів, самостійне вивчення за допомогою підручників, інтернет-статей або відеороликів, а також вивчення за допомогою спеціальних програм. В наш час подібних програмних рішень дуже багато: Duolingo, Lingualeo, Busuu, Memorise і багато інших. Одні спеціалізуються на граматиці, інші на лексиці. Одні виконані в ігровій формі, інші - в строгій. Варіантів дуже багато, користувач може сам обрати які навички, і в який момент часу розвивати. 3 одного боку це добре для людей, що чітко знають, що їм потрібно вивчати, і який спосіб для них найефективніший. Але у більшості випадків - це суттєвий мінус, адже не має чіткої системи, або вона недостатньо ефективна.

Запропоноване в даній роботі рішення засноване на методі інтервального повторення пройденого матеріалу. Це метод, при якому кожне конкретне слово потрібно повторювати не через рівні інтервали часу (щодня), не раз на тиждень (приділяючи цьому багато часу), i не коли «згадали», а за методикою коли інтервал повторення з часом збільшуються. При цьому важливо перший раз повторити інформацію майже одразу, другий раз, наприклад, через годину, потім через день, через тиждень, через місяць. Ці дані опираються на дослідження Еббінгауза, який запропонував криву забування (рис. 2). Він з'ясував, що ми починаємо забувати інформацію відразу після вивчення, втрачаючи за перший день, до 60\% знань [2]. Далі процес забування матеріалу сповільнюється. Однак з графіка видно, що при періодичному повторенні інформація міцно запам'ятовується на довгий період. 


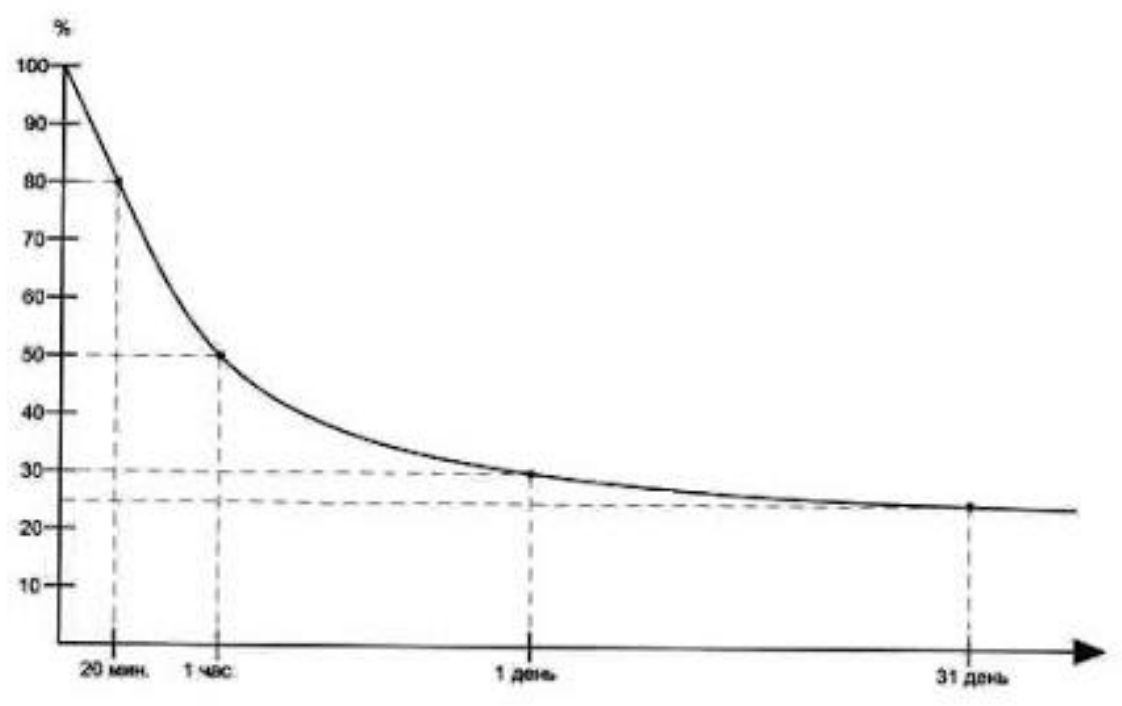

Рис. 2. Крива забування Еббінгауза

Результатом роботи $є$ Web-додаток, що написано мовою РНP 3 використанням системи управлінням базами даних MySQL. Реалізацію обрано у вигляді веб-додатку з трирівневою архітектурою MVC. Додаток не містить зайвої інформації, при цьому робить акцент на головному.

Впровадження такої програмної системи підвищує ефективність запам'ятовування пройденого матеріалу, що може бути використованим як самостійний інструмент для поповнення лексики и повторення граматики, так і в якості додаткового інструмента, що може підвищити ефективність вивчення матеріалу при роботі з репетиторами або на курсах.

\section{Список використаних джерел:}

1. Колесник А. А., Волкова С. А. Актуальність володіння іноземною мовою в сучасному світі// Молодий вчений. - 2017. - № 3 (137). - С. 562-564.

2. І. Ф. Прокопенка Психологія: підручник для студентів вищих навчальних закладів; худож.-оформлювач Ю. Ю. Романіка. — Харків: Фоліо, 2012. — 863 с. ISBN 978-966-03-5950-5.

Шевченко Іванна Юріївна, здобувач вищої освіти кафедри технології м'яса і м'ясних продуктів Національний університет харчових технологій, Україна

Науковий керівник: Чернюшок Ольга Анатоліївна, канд. техн. наук, доцент кафедри технології м'яса і м'ясних продуктів Національний університет харчових технологій, Украӥна

\section{ВИКОРИСТАННЯ МОЛОЧНОЇ СИРОВИНИ ДЛЯ РОЗРОБКИ РЕЦЕПТУРИ М'ЯСНИХ НАПІВФАБРИКАТІВ}

М'ясні напівфабрикати дуже швидко увійшли в наше життя та міцно в ньому влаштувались. Реагуючи, на потребу людей у швидкій, зручній, смачній та різноманітній їі, харчові підприємства України збільшили та покращили випуск м'ясних напівфабрикатів у широкому асортименті та різних цінових категоріях. 
Дивлячись на те, що м’ясопродукти користуються великим попитом серед більшості населення країни, проблема підвищення їх біологічної цінності та ресурсозбереження стає все більш актуальною та своєчасною.

Під час проведення аналізу науково-технічної вітчизняної та закордонної літератури свідчить проте, що чітко визначилася тенденція створення харчових продуктів комбінованого складу. Розроблення даного виду продуктів дозволяє збагатити традиційні вироби, незамінними нутрієнтами, а отже, забезпечити високий рівень збалансованості по амінокислотному, вітамінному складу, розширити асортимент та підвищити стійкість організму до шкідливих факторів навколишнього середовища.

Виходячи $з$ вище наведеного, вдосконалення технології комбінованої харчової продукції, а саме, м'ясних напівфабрикатів з біологічно активними компонентами молочної сировини, $є$ перспективним у розширенні асортименту і підвищенні харчової та біологічної цінності нових видів м'ясних продуктів. Отже, метою досліджень, результати яких висвітленні, $є$ теоретичне та експериментальне обгрунтування доцільності використання сухої молочної сироватки збагаченої $\mathrm{Mg}$ та $\mathrm{Mn}$, в складі м'ясних напівфабрикатів.

Одним з найбільш цінних компонентів молока є сироваткові білки, вміст яких у сироватці досягає 0,5..1,5\%. Головними з них є $\beta$-лактоглобулін (7..12\% від загальної кількості білків молока), лактальбумін (2..5\%), альбумін сироватки крові, імуноглобуліни і компоненти протеозо-пептонної фракції. Крім них в сироватці містяться лактоферин, ферменти та інші компоненти. Сироваткові білки (альбуміни і глобуліни) мають цінні біологічні властивості, вони містять оптимальний набір життєво необхідних амінокислот, $\mathrm{i}$ 3 точки зору фізіології харчування, наближаються до амінокислотної шкали «ідеального» білку, тобто білку, в якому співвідношення амінокислот відповідає потребам організму [1].

В сухій молочній сироватці збагаченій $\mathrm{Mg}$ та $\mathrm{Mn}$ присутній в невеликій кількості жир $(0,05 \ldots 0,4 \%)$, однак його цінність в тому, що він диспергований до кульок з діаметром менше 2 мкм [2]. Суха молочна сироватка збагачена $\mathrm{Mg}$ та $\mathrm{Mn}$ відрізняється високим вмістом мінеральних солей, макро- та мікроелементів. Основними макроелементами молочної сироватки є кальцій, фосфор, магній, калій, натрій, хлор і сірка (знаходиться в складі білків). В складі сироваткових білків присутні такі мікроелементи: залізо, мідь, цинк, манган, алюміній, селен, йод та інші [3].

Технологічними перевагами сироваткових білкових продуктів $\epsilon$ можливість застосування їх як часткову заміну м'ясного білку, жиру та інших інгредієнтів, що традиційно використовуються для покращення властивостей емульсії, а також із метою: емульгувати жировмісні компоненти; зменшити ризики утворення бульйоно-жирових напливів при термообробці; розкрити білки м'яса; зменшити собівартість продукції; покращити смакові характеристики готових виробів; знизити втрати під час термообробки; підвищити пружність та покращити консистенцію готових виробів в процесі приготування та зберігання [4].

Для досягнення поставленої мети вирішувалися наступні задачі: вивчення можливості використання сухої молочної сироватки збагаченої $\mathrm{Mg}$ та $\mathrm{Mn}$ в технології напівфабрикатів; розрахунок оптимальної кількості внесення сироватки; вивчення органолептичних, фізико-хімічних показників розроблених напівфабрикатів

Предметом дослідження були обрані м'ясні напівфабрикати у тістовій оболонці, виготовлені за традиційною технологією. В якості наповнювача застосовували суху молочну сироватку збагачену $\mathrm{Mg}$ та $\mathrm{Mn}$. В розроблених рецептурах було внесено суху молочну сироватку в кількості 0,62 \% до маси фаршу.

Наукові дослідження свідчать, що за сенсорними показниками експериментальні зразки не поступаються традиційним виробам, а за деякими показниками навіть кращі. 
Напівфабрикати з додаванням сироватки мали приємніший смак і запах, що обумовлене введенням в їх склад молочних компонентів.

Фізико-хімічні показники виробів відповідали вимогам діючої нормативної документації [5].

Отже, на підставі вищезазначеного можна зробити висновок про те, що результати проведених досліджень підтверджують можливість створення повноцінних напівфабрикатів у тістовій оболонці, 3 раціональним використанням сухої молочної сироватки збагаченої $\mathrm{Mg}$ та Mn.

У подальшому для удосконалення технологічного процесу виробництва напівфабрикатів, з використанням сухої молочної сироватки збагаченої $\mathrm{Mg}$ та $\mathrm{Mn}$, буде досліджено мікробіологічні характеристики продукту.

\section{Список використаних джерел:}

1. Токаев Э.С., Баженова Е.Н., Мироедов Р.Ю. Сывороточные белки для функциональных напитков// Молочная промышленность. - 2007, №10. -с.55

2. Храмцов А.Г., Нестеренко П.Г. Технология продуктов из молочной сыворотки: Учебное пособие. М.:ДеЛи принт, 2004.- 587c

3. Кочубей-Литвиненко, О. В. Нові підходи до мікроелементного збагачення сухих концентратів із молочної сироватки / О.В.Кочубей-Литвиненко, О. А. Чернюшок // Наукові праці Національного університету харчових технологій. - 2017. - Т. 23, № 5, Ч. 1. - С. 176-185.

4. Чернюшок, О. А. Удосконалення технології напоїв із сироватки молочної, обробленої електроіскровими розрядами : автореф. дис. ... канд. тех. наук : спец. 05.18.04 «Технологія м’ясних, молочних продуктів і продуктів з гідробіонтів» / Чернюшок Ольга Анатоліївна; НУХТ. - К., 2015. - 25 с.

5. ДСТУ 6028:2008 Напівфабрикати з м'ясом у тістовій оболонці заморожені. Загальні технічні умови. Чинний від [2009-04-01]. Вид. офіц. Київ : Держспоживстандарт України, 2009. 35 с

Іброхімова Аліка Айніддінівна, здобувач вищої освіти факультету комп'ютерних наук та інженерії

Державний вищий навчальний заклад

«Украӥнський державний хіміко-технологічний університет», Украӥна

\section{Наукові керівники:}

Тітова Олена Василівна, кандидат технічних наук, доцент кафедри комп'ютерно-інтегрованих технологій та автоматизації Державний вищий навчальний заклад «Український державний хіміко-технологічний університет», Україна

Лосіхін Дмитро Анатолійович, старший викладач кафедри комп’ютерно-інтегрованих технологій та автоматизації

Державний вищий навчальний заклад

«Украйнський державний хіміко-технологічний університет», Украйна

\section{ВИКОРИСТАННЯ КОНЦЕПЦІЇ НЕВИЗНАЧЕНОСТІ ПРИ ВИМІРЮВАННІ ВИТРАТИ РЕЧОВИНИ}

У даній роботі розглянута проблема визначення якості результату вимірювання витрати речовини.

Метою будь-якого вимірювання є визначення значення вимірюваної величини, однак для ухвалення рішення за результатами вимірювання на підставі тільки значення недостатньо, необхідна оцінка якості вимірювання. 
Якість вимірювань характеризується такими показниками, як точність, правильність і достовірність. Ці показники повинні визначатися за оцінками, до яких пред'являються вимоги спроможності, незміщення і ефективності. Одним з основних показників якості вимірювань $є$ точність, як кількісна характеристика якої традиційно використовується похибка, зокрема, часто застосовують квазістатистичний підхід, згідно з яким знаходять довірчий інтервал сумарної похибки. Однак сучасна теорія дещо інакше підходить до оцінки якості результату виконаного виміру. Перш за все, звертається увага на те, що експериментатору відомий результат вимірювання і невідомо справжнє значення, а тому для оцінки якості результату неможливо користуватися похибкою, як ступенем його відхилення від невідомого істинного значення вимірюваної величини. Тому в такому випадку необхідно використовувати іншу кількісну характеристику якості вимірювання. У цьому підході з одного боку не використовується поняття істинного значення величини, оскільки воно невідомо, i, з іншого боку, реалізовано уніфікований підхід до кількісної оцінки якості результату незалежно від походження і способу впливу різних чинників на результат вимірювання. Загалом, невизначеність результату вимірювання кількісно відображає брак знань про різні аспекти вимірювання конкретної величини.

Дослідження особливостей застосування концепції невизначеності для оцінки точності результату вимірювань в витратометрії, зокрема електромагнітних витратомірів, практично не розглянуті. Таким чином, актуальним завданням є розробка методології застосування концепції невизначеності в галузі вимірювання витрати.

У даній роботі виконана оцінка невизначеності вимірювання витрати електромагнітним витратоміром, який лежить в основі дозатора при заданій дозі $\mathrm{Q}=50$ л. Технічні переваги електромагнітного методу перетворення при створенні приладів вимірювання витрати електропровідних рідин загальновідомі. Ці переваги зумовили застосування електромагнітних перетворювачів в широкому діапазоні швидкостей течії рідини (від $10^{-2} \mathrm{M} / \mathrm{c}$ до $10 \mathrm{~m} / \mathrm{c}$ і більше) в трубопроводах з діаметрами від $10^{-2}$ до 3,6 м для великої різноманітності рідин і пульп, електропровідність яких лежить в межах від $10^{-3}$ см/м до $10 \mathrm{~cm} / \mathrm{M}$.

Впровадження інтелектуальних електромагнітних перетворювачів витрати, в яких високі метрологічні характеристики забезпечуються завдяки управлінню процесом вимірювання i цифровій обробці вимірювальної інформації за допомогою мікропроцесорного пристрою, дозволило підвищити точність електромагнітних витратомірів. Електромагнітні перетворення такого типу використовуються в харчовій промисловості для дозування невеликих кількостей (до 50 л) рідких інгредієнтів, що висуває особливі вимоги до подання та оцінювання якості вимірювань. Вимірювальна система витратомірів складається з проточної камери, пари котушок, що створюють в цій камері магнітне поле, і пари сенсорних електродів, вбудованих в стіни камери. Рухомим в магнітному полі провідником служить електропровідна робоча рідина. Оцінювані величини, які впливають на результат вимірювання, є некорельованними так як, всі вони визначаються за допомогою різних приладів, і методів і не пов'язані одна з одною.

Бюджет невизначеності вимірювання витрати електромагнітним витратоміром, який складений на підставі розрахунків, виконаних в даному дослідженні, представлений в табл. 1.

Таблиия 1

Бюджет невизначеності

\begin{tabular}{|c|c|c|c|c|c|}
\hline $\begin{array}{c}\text { Вхідна } \\
\text { величин } \\
\mathrm{a} \mathrm{Xi}\end{array}$ & $\begin{array}{c}\text { Оцінка } \\
\text { вхідної } \\
\text { величини } \\
\mathrm{Xi}\end{array}$ & $\begin{array}{c}\text { Стандартна } \\
\text { невизначеність } \\
\mathrm{U}(\mathrm{Xi})\end{array}$ & $\begin{array}{c}\text { Розподіл } \\
\text { ймвірності } \\
\text { вхідної } \\
\text { величини }\end{array}$ & $\begin{array}{c}\text { Коефіцієнт } \\
\text { чутливості }\end{array}$ & $\begin{array}{c}\text { Внесок в } \\
\text { невизначеність } \\
\mathrm{Ui}(\mathrm{y})\end{array}$ \\
\hline $\mathrm{D}$ & $25,01 \mathrm{мм}$ & 0,1176 мм & Нормальний & 0,96 & 0,112896 \\
\hline $\mathrm{K}$ & 0,17 & 0,098 & Нормальний & $-0,141$ & $-0,013818$ \\
\hline
\end{tabular}


Продовження табл. 1

\begin{tabular}{|c|c|c|c|c|c|}
\hline $\begin{array}{c}\text { Вхідна } \\
\text { величин } \\
\mathrm{a} \mathrm{Xi}\end{array}$ & $\begin{array}{c}\text { Оцінка } \\
\text { вхідної } \\
\text { величини } \\
\mathrm{Xi}\end{array}$ & $\begin{array}{c}\text { Стандартна } \\
\text { невизначеність } \\
\mathrm{U}(\mathrm{Xi})\end{array}$ & $\begin{array}{c}\text { Розподіл } \\
\text { ймовірності } \\
\text { вхідної } \\
\text { величини }\end{array}$ & $\begin{array}{c}\text { Коефіціснт } \\
\text { чутливості }\end{array}$ & $\begin{array}{c}\text { Внесок в } \\
\text { невизначеність } \\
\text { Uі (у) }\end{array}$ \\
\hline $\mathrm{D}$ & $25,01 \mathrm{мм}$ & $0,1176 \mathrm{мм}$ & Нормальний & 0,96 & 0,112896 \\
\hline $\mathrm{K}$ & 0,17 & 0,098 & Нормальний & $-0,141$ & $-0,013818$ \\
\hline $\mathrm{B}$ & $0,2079 \mathrm{~T}$ & $0,0004 \mathrm{~T}$ & Нормальний & 1 & 0,0004 \\
\hline $\mathrm{Ei}$ & $0,1298 \mathrm{~B}$ & $0,0061 \mathrm{~B}$ & Нормальний & $-0,005$ & $-0,0000305$ \\
\hline $\mathrm{Q}$ & 49,86 л & & & & 0,015 \\
\hline
\end{tabular}

[авторська розробка]

Висновки: у даній роботі розроблений алгоритм оцінки невизначеності в галузі вимірювання витрати та представлений бюджет невизначеності. Зроблено оцінку невизначеності відповідно до розробленого алгоритму i представлений бюджет невизначеності.

\section{Список використаних джерел:}

1. Фридман А. Э. Основы метрологии. Современный курс. - СПб.: Профессионал, 2008. - 284 с.: ил.

2. Guide to the Expression of Uncertainty in Analytical Measurement. ISO, Geneva, 1993. ISBN 92-67-10188-9.

3. РМГ 43-2001. Применение «Руководства по выражению неопределенности измерений»: рекомендации по межгосударственной стандартизации / Межгосударственный совет по стандартизации, метрологии и сертификации. - Минск.: Изд-во стандартов, 2002. - 26 с.

4. ГОСТ Р 54500.1-2011. Руководство ИСО/МЭК 98-1: 2009. Неопределенность измерения. Ч. 1: Введение в руководства по неопределенности измерения. - М.: Стандартинформ, 2012. - 24 с.

5. Иванова Г.М., Кузнецов Н.Д., Чистяков В.С. Теплотехнические измерения и приборы: учебник для вузов / 2-е изд., перераб. и доп. - М.: Издательство МЭИ, 2005. - 460 с.,ил.

6. Демидова Н.М., Поджаренко В.О. Застосування концепції невизначеності в області вимірювання витрат // Метрологія та вимірювальна техніка (Метрологія - 2006): Зб. наук. праць п’ятої наук.-техн. конференції (м. Харків, 10-12 жовтня 2006 р.) - Харків: ННЦ «Інститут метрології». - 2006. - Т.2. - 199-203 с.

Лопатко Юрій Миколайович, аспірант кафедри машин і апаратів харчових та фармацевтичних виробництв

Національний університет харчових технологій, Украӥна

\section{ЖИРОВІ МАСИ У КОНДИТЕРСЬКІЙ ПРОМИСЛОВОСТІ ТА ОСОБЛИВОСТІ РОБОТИ ОБЛАДНАННЯ ДЛЯ ЇХ ПЛАВЛЕННЯ В ТЕХНОЛОГІЧНИХ ПРОЦЕСАХ ПЕРЕРОБКИ}

Однією з галузей харчової промисловості, яка споживає жири і масла, є кондитерське виробництво, в якому вони є обов'язковими компонентами різних цукеркових мас, в тому числі, шоколадної і жирової глазурі. Жири забезпечують структурні показники кондитерських виробів, підвищують харчову цінність, покращують смак і сприяють збереженню аромату. Найбільш широко використовують в кондитерському виробництві натуральні масла, виділені 3 дорогої імпортованої сировини - какао-бобів, жирові замінники какао-масла та кондитерські жири. Жирно-кислотний склад зазначених жирів представлений, в основному, насиченими жирними кислотами. Але вони характеризуються низьким вмістом біологічно та фізіологічно цінних компонентів.

У кондитерській та хлібопекарській промисловості застосовуються найрізноманітніші види жирів. Одні 3 них $є$ складовою частиною використовуваної сировини, інші у вигляді товарних сортів додаються в рецептуру різних виробів. 
В інших випадках застосовуються в основному тверді натуральні рослинні жири i штучно затверділі (гідрогенізовані) рослинні жири. 3 тваринних жирів застосовується вершкове масло.

Рідкі рослинні масла використовуються в невеликих кількостях, головним чином як допоміжні матеріали (мастило та ін.).

Застосування в рецептурі кондитерських виробів твердих жирів необхідно, так як вони надають готовим виробам необхідну твердість, пластичність, температуру плавлення і застигання.

До твердих натуральних рослинних жирів, які переробляються в кондитерській промисловості, відносять і масло-какао - твердий жир, який не містить гліцеридів летючих жирних кислот, і кокосове, що має в своєму складі значну кількість летких жирних кислот.

Температура плавлення масла-какао нижче температури людського тіла $\left(32-36^{\circ} \mathrm{C}\right)$, тому кондитерські вироби, що містять масло-какао, легко плавляться в роті, не залишаючи жирного присмаку.

Кокосове масло по консистенції при кімнатній температурі схоже 3 топленим коров'ячим маслом. У кондитерської промисловості кокосове масло застосовується при виготовленні багатьох сортів цукерок, карамельних начинок (олійно-цукрових) і начинок для вафель.

Крім натуральних твердих жирів, асортимент яких дуже обмежений, широке застосування в кондитерській і хлібопекарській промисловості отримали штучно затверділі рослинні масла (Саломаси), на основі яких виробляють кондитерські жири, маргарини, кулінарні та хлібопекарські жири.

Саломас - це отриманий синтетичним шляхом жир. Проводиться він з рослинного масла шляхом насичення його молекул воднем. Подвійні зв'язку в молекулі розриваються і рослинне масло зі стану рідкого жиру переходить в твердий стан - в саломас. Такий жир в природі не зустрічається.

Технологічний процес отримання шоколадної глазурі на кондитерських фабриках включає наступні операції:

- прийом і зберігання шоколаду в твердому вигляді;

- плавлення шоколаду;

- розподілення шоколадної глазурі на продукцію;

- охолодження продукції;

- фасування і пакування продукції.

Технологічний процес плавлення шоколадних мас здійснюється термічним способом в плавильних камерах, куди апаратником завантажується порція блоків шоколаду. Шоколад плавиться за рахунок подачі гарячої води в теплову сорочку плавильної камери. Далі гарячою водою прогрівається ванна до потрібної температури та за рахунок системи автоматичного регулювання підтримується температура глазурі у ванні. Розплавлена шоколадна глазур надходить на продукцію (печиво, зефір і ін.).

Необхідна якість кінцевого продукту забезпечується дотриманням технологічного режиму кожної операції, тобто підтриманням нормативних значень технологічних параметрів, в тому числі, за рахунок впровадження автоматизованих систем. Основним $є$ процес плавлення та темперування шоколаду. Порушення температурного режиму плавлення шоколаду викликає його пригорання, що негативно позначається на кольорі, смаку і консистенції шоколадної глазурі.

Зменшення бракованої продукції та необхідності іï переробки і утилізації при плавленні шоколадної глазурі забезпечується впровадженням автоматизованої системи.

Висновки. Процес плавлення є одним з головних складових при виробництві шоколадної глазурі, адже саме дотримання регламентованих температурних режимів відносно тої чи іншої шоколадної маси забезпечує отримання продукції високої якості. 
Безруков Олександр Олександрович, здобувач фахової передвищої освіти відділення комп'ютерних та видавничих технологій Галииький коледж імені В ячеслава Чорновола, Украӥна

Науковий керівник: Павлюс Василь Петрович, викладач циклової комісії інформатики та комп'ютерних дисциплін

Галищький коледж імені В 'ячеслава Чорновола, Украӥна

\section{ЗОВНІШНС НЕЗАЛЕЖНЕ ОЦІНЮВАННЯ ЯКОСТІ ОСВІТИ В УКРАЇНІ: ПРОГРАМИ ДЛЯ ПІДГОТОВКИ ТА ПРОХОДЖЕННЯ}

Одним із особистих прав кожної людини є право на здобуття вищої освіти. Здійснення цього права не повинна залежати від певних привілеїв, майнових можливостей родини потенційного здобувача вищої освіти. Держава має створити рівні умови кожному своєму громадянину для ії здобуття.

Однією 3 форм забезпечення доступності до вищої освіти є зовнішнє незалежне оцінювання (далі - ЗНО). В Україні створено чимало можливостей отримання знань для успішної здачі ЗНО, але нами пропонується власний сервіс для тестування та підготовки до ЗНО майбутніх абітурієнтів, учнів шкіл та професійно-технічних закладів, студентів коледжів.

Система освіти України почала формуватися у 1990-і роки в умовах змін в житті суспільства, в контексті цивілізаційних трансформацій, які згенерувались у зв'язку 3 поширення нових освітніх технологій та розширенням можливостей розвитку людини.

Діяльність сучасної системи освіти України забезпечується низкою освітніх нормативно-правових актів, основними з яких є: Конституція України, Закон України «Про освіту», Закон України «Про загальну середню освіту» тощо. Ці нормативні акти визначили головні напрямки модернізації змісту, форм і методів навчання. Окрім вище наведених документів, важливими є і Державна національна програма «Освіта. Україна XXI століття» та Національна доктрина розвитку освіти.

Для переходу між рівнями освіти в Україні існують певні іспити. Їх метою є перевірка рівня знань учнів шкіл, закладів вищої освіти та майбутніх абітурієнтів. Існує два основних державних екзамени - Державна підсумкова атестація (далі - ДПА) та ЗНО [1]. Перший учні здають наприкінці дев'ятого класу для фіксації знань та подальшого допуску до навчання у 10-11 класах. ДПА - це форма контролю відповідності освітнього рівня випускників загальноосвітніх навчальних закладів I-III ступенів, коледжів та професійнотехнічних закладів, що надають загальну середню освіту.

Наступний важливий екзамен - це ЗНО. Система ЗНО в Україні створювалася та вдосконалювалася протягом багатьох років. Основне іiі завдання - забезпечити кожному рівні умови доступу до вищої освіти. Ця система мінімізує корупційні ризики і дає можливість талановитим дітям реалізувати свій потенціал.

Оскільки ЗНО - це дуже важливий рубіж у житті учнів для подальшого навчання, його потрібно успішно здати. Для цього необхідно підготуватися усіма можливими способами. Один з найпопулярніших у нашому суспільстві є особистий репетитор. Цей спосіб підготовки є досить ефективним, оскільки наставник приділяє весь час заняття одному учню, завдяки чому останній отримує максимальну кількість знань та має можливість зворотного зв'язку. Однак, знайти професійного репетитора не так легко та й вартість такого навчання доволі висока.

У наш час все більшої популярності набуває онлайн підготовка. Одним із фаворитів є сайт zno-osvita.ua. Вiн представляє з себе застосунок для проходження тестів ЗНО онлайн та підготовки майбутніх абітурієнтів для проходження оцінювання. Спосіб виконання всіх тестових завдань на сайті максимально наближений до реальних тестів, а форма надання 
відповіді відповідає виду, який пропонується абітурієнтам у бланку відповідей під час проходження тестів ЗНО. Одним з його недоліків є те, що він обмежений лише сесіями ЗНО, тобто не має можливості підготовки з певних дисциплін та тем.

Розроблений нами сервіс представляє собою платформу, яка надає можливість майбутнім абітурієнтам підготуватися до ЗНО. Окрім проходження попередніх сесій, особа матиме можливість підготовки з предметів згідно тематики, а також готових варіантів, які $\epsilon$ наближеними до ЗНО. Даний сервіс буде реалізовано у вигляді веб-застосунку.

Веб-застосунок - клієнт-серверний застосунок, в якому клієнт взаємодіє з вебсервером за допомогою браузера. Логіка веб-застосунку розподілена між сервером i клієнтом, зберігання даних здійснюється на сервері, обмін інформацією відбувається по мережі. Однією з переваг такого підходу є незалежність клієнта від конкретної операційної системи користувача, тому веб-застосунки є багатоплатформеними службами.

Для реалізації даного застосунку було використано наступний набір технологій:

- Typescript та Node.js з фреймворком React для клієнтської частини;

- Typescript та Node.js з фреймворком Fastify для серверної частини;

- Typescript - мова програмування, яка за допомогою компілятора транслюється в код JavaScript.

Основні переваги над JavaScript це [2]:

- статична типізація - можливість явного визначення типів;

- підтримка використання повноцінних класів(ООП);

- підтримка підключення модулів.

Node.js - це платформа з відкритим кодом для виконання мережевих застосунків, написаних з використанням мови JavaScript.

Дані технології надають зручність у розробці програмних застосунків та зменшують час на їх створення. Фреймворк React було обрано для зручної роботи з DOM та легкої маніпуляції будь-якими даними за рахунок менеджера сховища, котрий містить загальні дані клієнтської частини у пам'яті веб-браузера. Фреймворк Fastify використано тому, що він може опрацьовувати до 70-ти тис. запитів за секунду. Також він надає велику кількість засобів та механізмів для швидкої та зручної розробки.

Головна сторінка веб-застосунку містить кнопки для аутентифікації та реєстрації, текстове поле для пошуку дисципліни та візуальне відображення наявних дисциплін. Головна сторінка сайту зображена на рисунку 1.

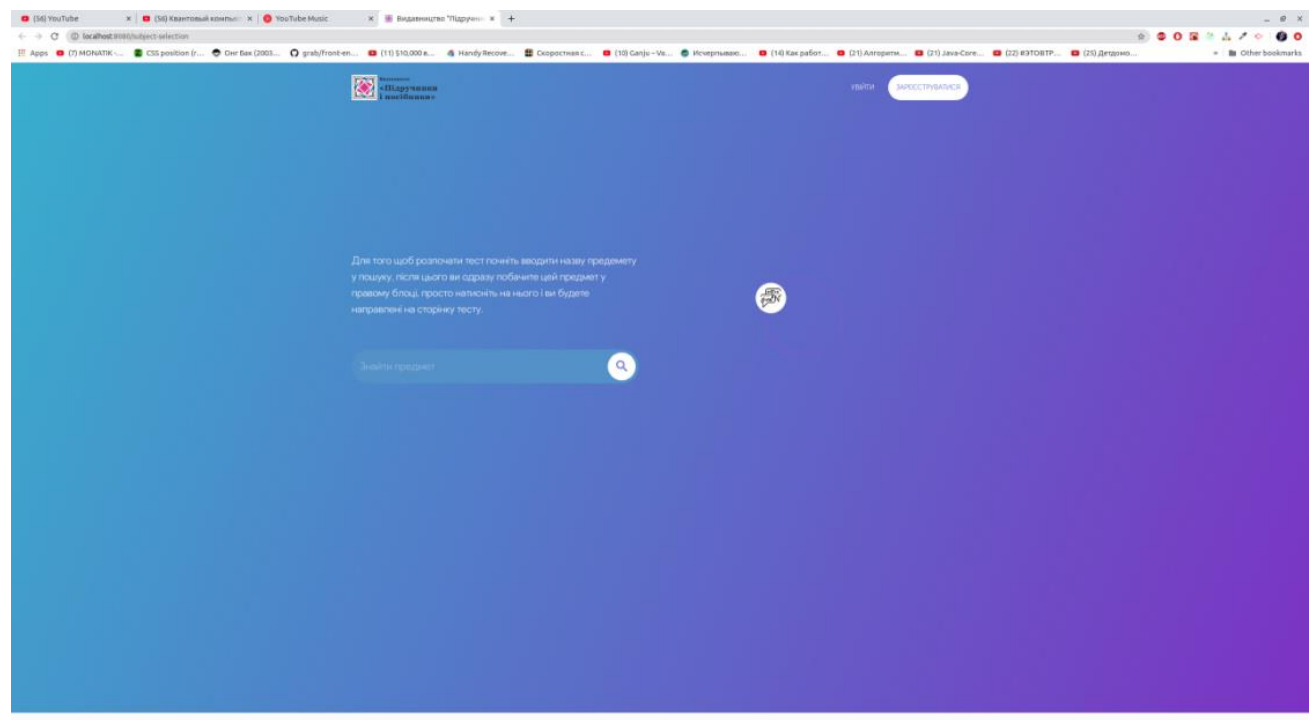

Рис. 1. Головна сторінка сайту

При виборі певного предмету користувач буде перенаправлений на сторінку налаштувань тесту (рисунок 2), де можна встановити його тип (за темою чи у вигляді 
повноцінних наборів тестів), а також чи буде це тренувальне тестування, чи на основі попередніх сесій ЗНО. Також можна встановити тривалість тесту та відображення правильних відповідей під час його проходження.

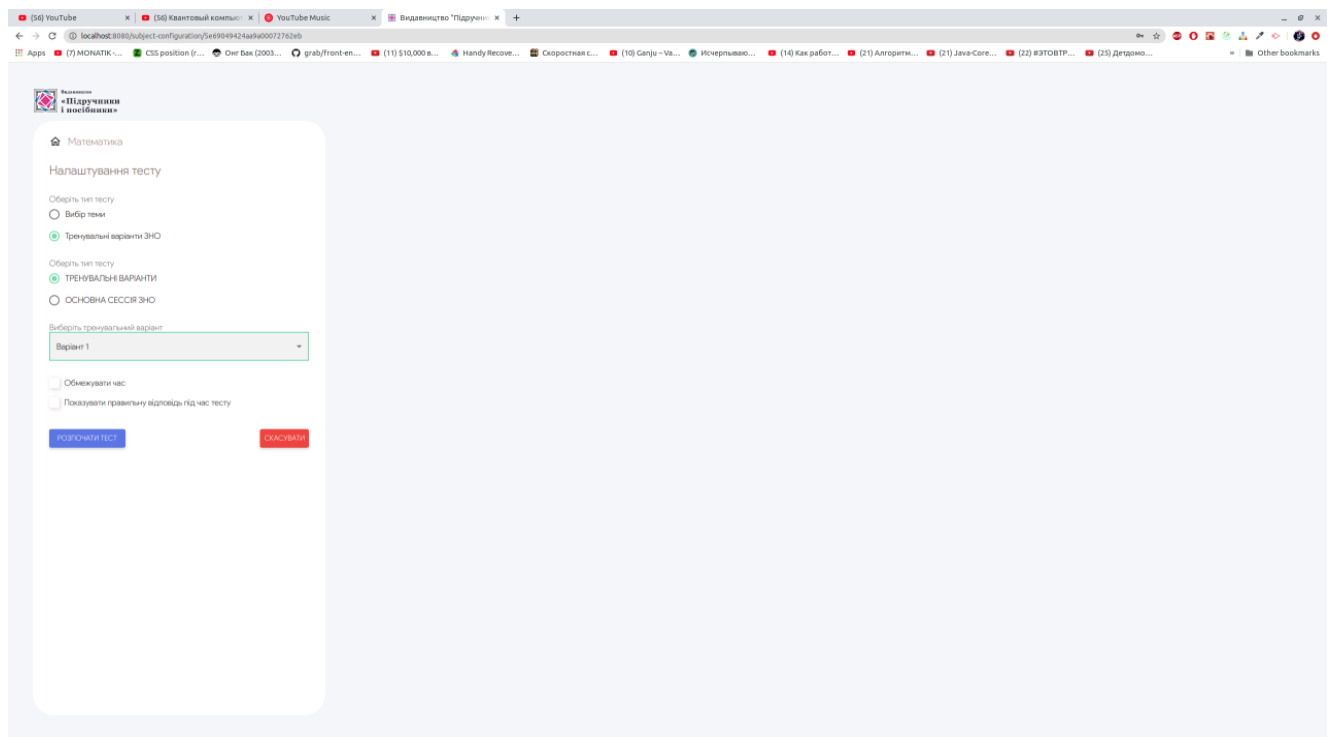

Рис. 2. Сторінка налаштувань тесту

Після здійснення усіх налаштування користувачу відкривається сторінка проходження тесту (рисунок 3), на якій міститься наступна інформація та елементи управління:

- панель прогресу - відображає головну статистику тесту (кількість правильних відповідей, кількість балів і т.д.);

- опис завдання;

- елементи управління, які дозволяють вибирати відповіді;

- смуга вибору номера бажаного завдання.

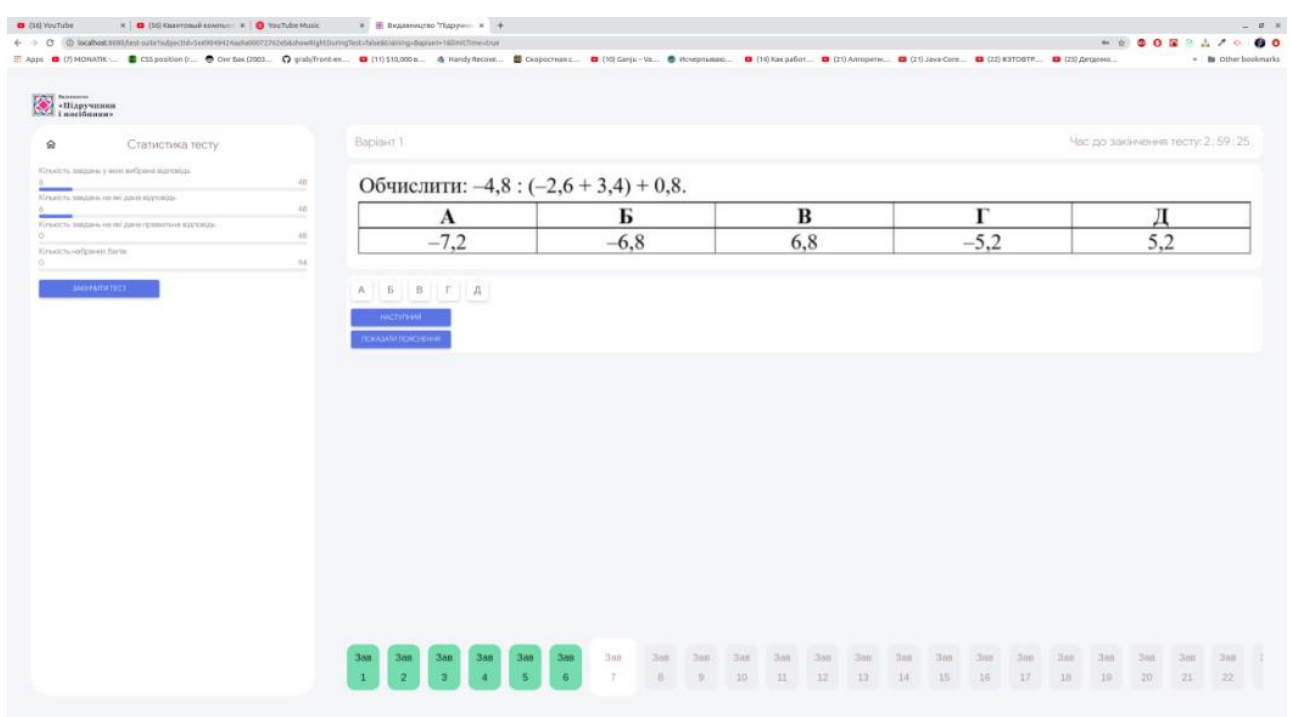

Рис. 3. Сторінка тесту

Висновки. Проведений нами аналіз показав, що системи онлайн навчання та підготовки до різноманітних іспитів набувають у нашій країні значної популярності. Саме це спонукало нас до створення власної онлайн платформи для підготовки до ЗНО. 
Список використаних джерел:

1. Державна підсумкова атестайія (2020). Вилучено $3 \mathrm{https://mon.gov.ua/ua/tag/derzhavna-pidsumkova-}$ atestatsiya

2. Результат порівняння різних фреймворків (2020). Вилучено 3 https://www.fastify.io/benchmarks

Михайлов Михайло Андрійович, студент

Одеський національний політехнічний університет, Украина

Науковий керівник: Кісель Анатолій Георгійович, доц., канд. техн. наук

Одеський національний політехнічний університет, Украина

\section{ІДЕНТИФІКАЦІЯ ОБ'ЄКТА ТА СИНТЕЗ САР ТЕХНОЛОГІЧНИМ ПРОЦЕСОМ ПАСТЕРИЗАЦІї}

Консервовані овочеві соки є натуральними продуктами, які використовуються в якості напоїв. Найбільшого поширення набув томатний сік.

Томатний сік отримують з зрілих томатів у вигляді однорідної маси, що містить м'якоть, в якій знаходиться вітамін С і провітамін А-каротин. Продукт повинен володіти хорошим натуральним смаком і запахом, мати гарний червоний або оранжево-червоний колір і містити не менше 4,5\% сухих речовин по рефрактометр. Сік консервують в натуральному вигляді, а іноді додають до нього кухонну сіль в кількості 0,6-1\%.

Консервований томатний сік містить цінні для людського організму хімічні речовини-цукру, кислоти, вітаміни, мінеральні речовини, зокрема залізо, і мікроелементи мідь і марганець.

За хімічним складом томатний сік близький до сировини. Він містить 4,5\% і більш сухих речовин, 2 4\% цукру, $0,2 \%$ клітковини, до 1\% азотистих речовин, має загальну кислотність 0,3-0,5\% при рН 4,3-4,45 і до 1\% золи.

Мінеральний склад томатного соку наступний (в мг\%): До -286, $\mathrm{Na}-165, \mathrm{Ca}-13, \mathrm{Mg}$ 26, Fe -0,7, P -32, Мп -0,1, J- 150 у / кг. У порівнянні з вихідною сировиною томатний сік містить менше заліза і марганцю і більше кальцію, магнію, калію і йоду. Зміни в мінеральному складі пов'язані в основному з видаленням шкірки і насіння.

Аромат томатного соку обумовлений вмістом спиртів і карбонільних сполук. До складу ароматичних речовин входять ненасичені сполуки, зі зміною яких може погіршуватися смак томатного соку. У пастеризованому томатному соку містяться складні ефіри, кількість яких в перерахунку на етилацетат становить 2 мг / л.

Консервований томатний сік містить таку кількість вітамінів (в мГ на 100 гр): каротин (в перерахунку на вітамін А) -0,5-1,0; В1- 0,01; В2 - 0,01; PР - 0,2; 3-14-21; пантотенова кислота - 0,25.

Втрати вітаміну С спостерігаються на всіх виробничих операціях і в сумі вони сягають 20-30\%. Велика частина цих втрат має місце при розливі та пастеризації соку. Якщо в процесі виробництва усунути контакт соку з повітрям (шляхом нагрівання маси перед віджиманням до кипіння або негайної деаерації віджатого соку під глибоким вакуумом) і стерилізувати сік в потоці до розливу, то можна зберегти в продукті $94 \%$ початкової кількості вітаміну С.

При тривалому зберіганні томатного соку може відбуватися подальше зменшення кількості аскорбінової кислоти. Ці втрати при зберіганні тим більше, чим більше залишається повітря в банках або бутлях з соком. Тому підвищені втрати вітаміну С в томатному соку спостерігаються при недостатньому заповненні тари, а також при малій 
величині утворюється в ній вакууму. Для того, щоб зберігати вітаміни та інші цінні біологічно активні речовини томатів, вироблення томатного соку ведуть в закритій системі, що виключає можливість негативного впливу кисню повітря.

Важливим показником якості томатного соку є його колір, який залежить в першу чергу від зрілості сировини.

Колір консервованого томатного соку пов'язаний з технологічним процесом. Кисень повітря викликає окислення лікопіну і погіршення забарвлення соку. Тривалий підігрів при високій температурі сприяє меланоідіновим реакцій, карамелізації цукрів, коагуляції білків i порушення колоїдної системи соку, що призводить до зміни кольору продукту. Потемніння соку може бути наслідком реакції між танином і солями заліза.

Вироблення томатного соку ведуть за такою схемою: мийка плодів; сортування та інспекція; ополіскування; дроблення; підігрівання дробленої маси; отжатие соку; гомогенізація; деаерація; підігрівання соку; розлив соку в тару; закупорювання тари; стерилізація та охолодження.Розглянемо технологічну схему виробництва томатного соку.

Суть процесу пастеризації наступна: рідкий або пюреподібний продукт нагрівається в тонкому шарі протягом 5-20 с. до температури $90-95^{\circ} \mathrm{C}$, а потім дуже швидко охолоджується, фасується і закупорювається в стерильних умовах в заздалегідь простерилізовану тару.

Для асептичного консервування в крупних ємкостях при продуктивності 2000 кг/год томатного соку призначена лінія А9-КСК (рис.1).

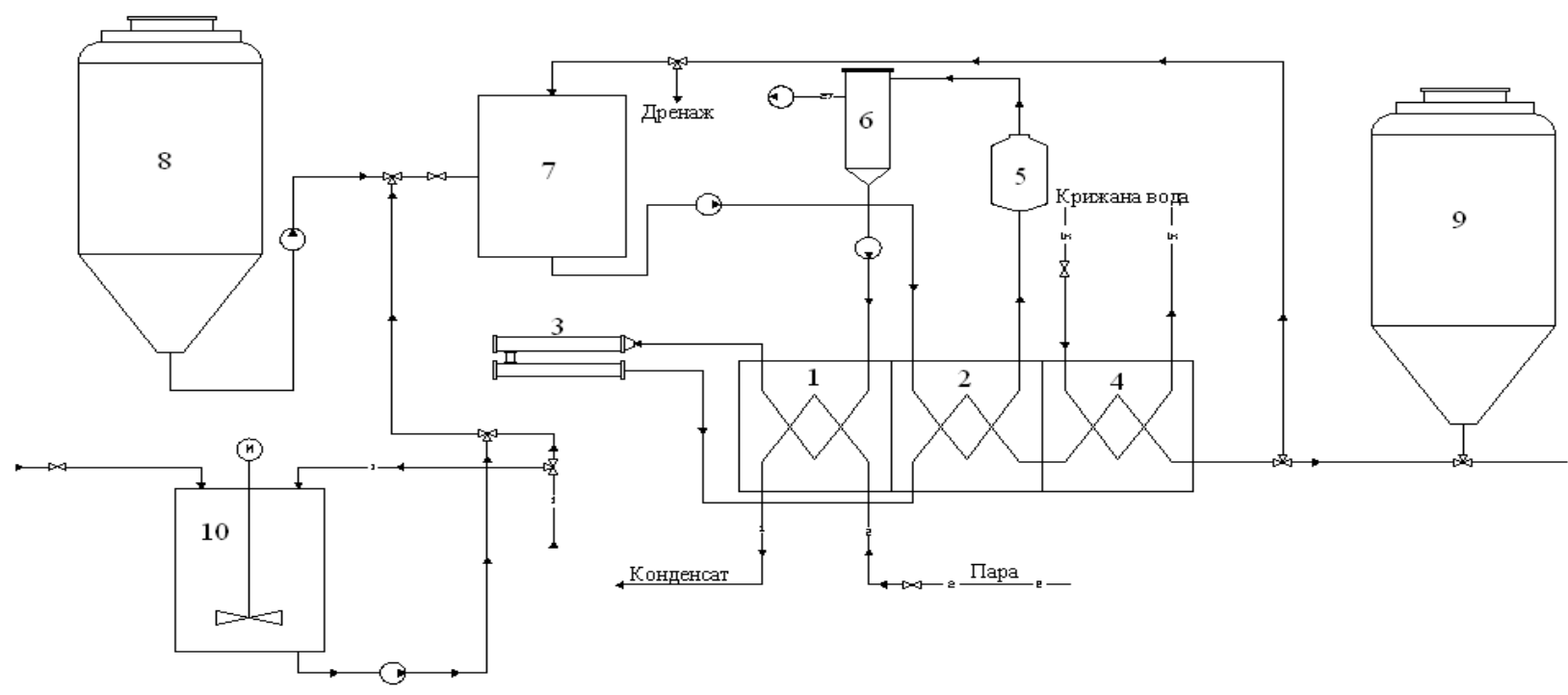

Рис. 1. Лінія пастеризації томатного соку «А9-КСК»

1 -Секиія пастеризаиіі; 2 -Секиія регенеративного охолодження;

3 - Секиія витримування; 4 - Секиія охолодження крижаною водою; 5 - Гомогенізатор; 6-Деаератор; 7 - Збірний бак; 8, 9-Смності для асептичного зберігання; 10 - Бак для приготування миючого розчину.

До складу лінії входить деаераційно-пастеризаційна установка (ДПУ), устаткування для миття і стерилізації машин, апаратів і ємностей, стерильні ємності, для тривалого зберігання продукту в стерильних умовах і видачі його на переробку.

В якості об’єкта для модернізації системи автоматизації $є$ деаераційно пастеризаційна установка (ДПУ) (рис.2). ДПУ - основний елемент лінії пастеризації томатного соку, так як при отриманні соку з основної сировини в ньому залишається велика кількість мікроорганізмів. Процес пастеризації дозволяє видалити з соку можливі мікроби, щоб забезпечити зберігання соку. 


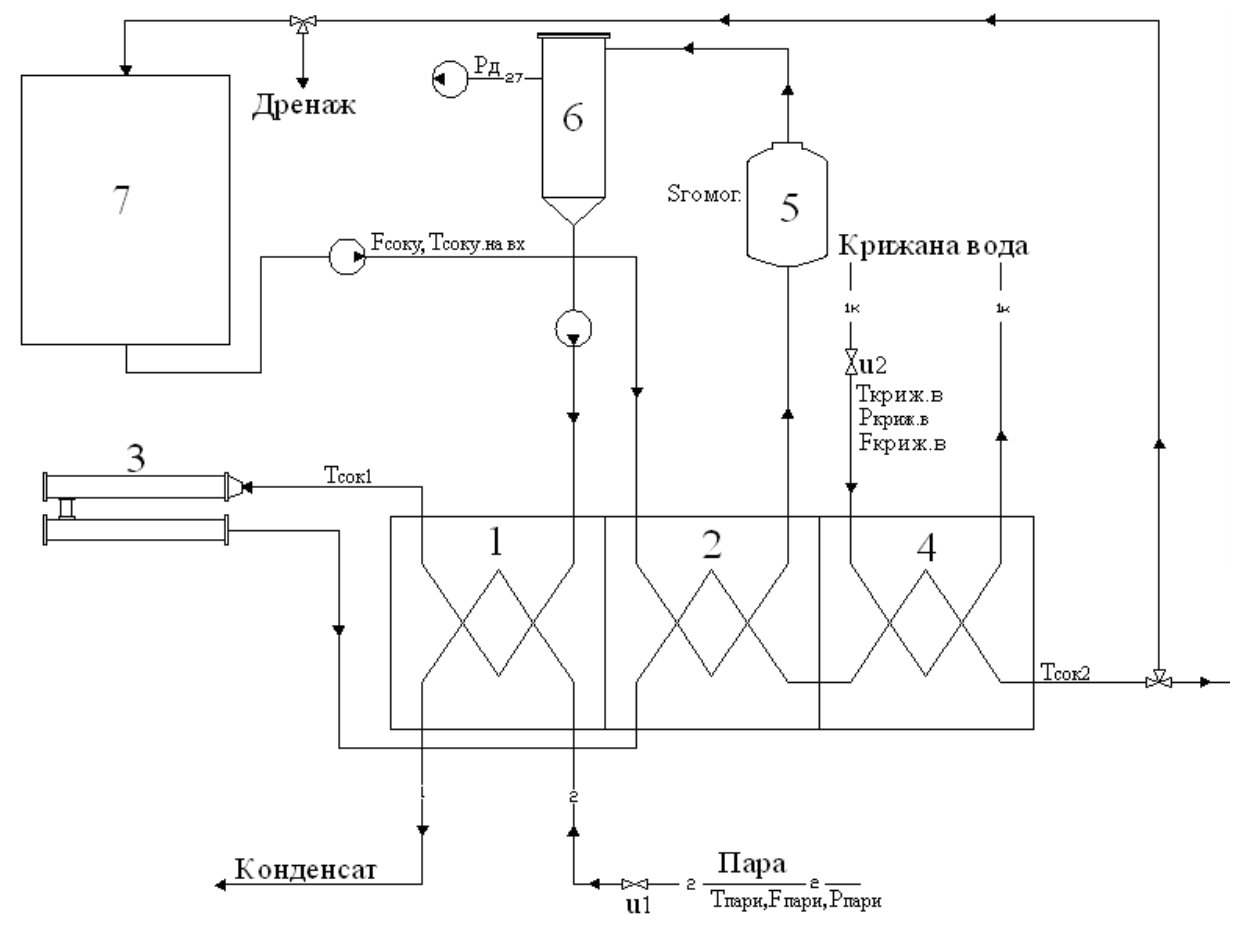

Рис. 2. Параметризована схема ДПУ

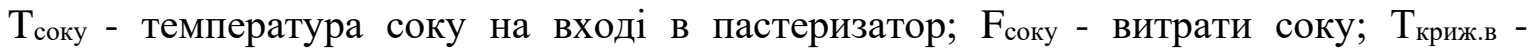

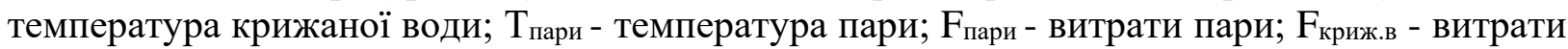
крижаної води; $\mathrm{u}_{1}$ - хід регулюючого органу подачі пари; $\mathrm{u}_{2}$ - хід регулюючого органу подачі

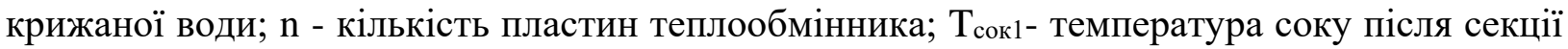

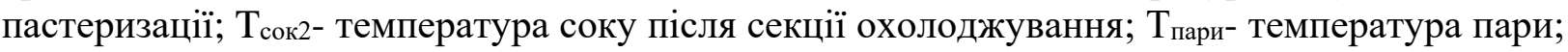

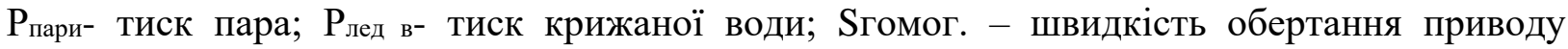
гомогенізатора; Рд. - тиск розрідження в деаераторі; В - ціна продукту; Y - втрати від браку; $\mathrm{G}$ - продуктивність установки.

Основними частинами ДПУ є гомогенізатор (5), деаератор (6), секції теплообмінників пастеризатора (1-4), зрівняльний бак (7), вакуум-насос, сокові насоси.

Деаератор (6) - виготовлений 3 нержавіючої сталі резервуар 3 днищем конусної форми, закритим зверху скляною кришкою. Всередині резервуара розташований перфорований циліндр який прилягає до кришки. До верхньої частини деаератора приєднаний піновловлювач. Розрідження в деаераторі підтримується в межах від 96 до 98,66 КПа за допомогою двоступінчатого водокільцевого вакуум-насосу. За рахунок розрідження сік засмоктується в деаератор, де через сопло подається на його кришку, розтікається по ії поверхні, тонкою плівкою опускається вниз по перфорованому циліндру і деаерується, після чого відкачується насосом для подальшої пастеризації.

Пластинчастий пастеризатор, установки ДПУ складається 3 чотирьох секцій: пастеризації (1), регенерації (2), витримування (3) та охолоджування (4).

Нагрів соку від 15 до $65^{\circ} \mathrm{C}$ здійснюється в пастеризаторі спочатку в секції регенерації (2) зустрічним потоком гарячого соку, потім до $95^{\circ} \mathrm{C}$ в секції пастеризації (1) паром. Витримка соку проводиться в трубчастому теплообмінному апараті (секції витримування (3)) протягом 60c. 3 витримувача сок проходить, віддаючи теплоту, через секцію регенерації (2) до секції остаточного охолоджування (4) крижаною водою з температурою $4-5^{\circ} \mathrm{C}$, температура охолодженого соку $20-25^{\circ} \mathrm{c}$.

Якщо заданий режим пастеризації не досягається, сік автоматично прямує на повторний нагрів. 
Допуски на відхилення поточних значень регламентованих параметрів діляться на тривалі і короткочасні. Допустимі відхилення визначають зону незначущих відхилень, посередині якої значення параметра можна вважати близьким до нормативного, тому ці відхилення не ліквідовують. Короткочасні допустимі відхилення параметрів перевищують зону незначущих відхилень і призводять до зниження ефективності процесу, тому вони допустимі тільки впродовж обмеженого часу, який задається і входить в регламент. Вихід параметрів за зону короткочасно допустимих відхилень свідчить про відхилення в технологічному процесі або в експлуатації устаткування, які можуть привести до аварії.

Таблиия 1

Таблиця регламентів

\begin{tabular}{|c|c|c|c|c|c|}
\hline \multirow{2}{*}{$\begin{array}{l}\text { Найменування } \\
\text { параметрів }\end{array}$} & \multirow{2}{*}{ Позначення } & \multirow{2}{*}{$\begin{array}{l}\text { Одиниці } \\
\text { вимірювання }\end{array}$} & \multirow{2}{*}{$\begin{array}{l}\text { Номінальне } \\
\text { значення } \\
\text { параметрів }\end{array}$} & \multicolumn{2}{|c|}{$\begin{array}{l}\text { Допустимі відхилення від } \\
\text { номінальних }\end{array}$} \\
\hline & & & & Довготривалі & Короткочасні \\
\hline $\begin{array}{l}\text { Температура соку } \\
\text { після секції } \\
\text { пастеризації }\end{array}$ & $\mathrm{T}_{\text {сок } 1}$ & ${ }^{\circ} \mathrm{C}$ & 95 & \pm 5 & \pm 10 \\
\hline $\begin{array}{l}\text { Температура соку } \\
\text { після секції } \\
\text { охолодження }\end{array}$ & $\mathrm{T}_{\text {сок } 2}$ & ${ }^{\circ} \mathrm{C}$ & 25 & \pm 5 & \pm 10 \\
\hline
\end{tabular}

Поточні значення нормативних параметрів завжди відрізняються від номінальних унаслідок зміни умов, за яких ведеться процес. Ці умови також характеризуються певними параметрами і можуть бути згруповані за деякими ознаками.

1. Сировинні параметри - характеризують властивості продукту, який йде у виробництво. До таких параметрів відносяться:

-температура соку на вході (Тсоку.вх)

-витрати соку (Fсоку)

2. Енергетичні параметри - характеризують енергію, яка підводиться до технологічного устаткування ззовні і витрачається на зміну властивостей продукту. До таких параметрів відносяться:

-температура пари (Тпара)

-температура крижаної води (Ткриж.в)

-тиск розрідження в деаераторі (Рд)

-швидкість обертання приводу гомогенізатора (Кгомог.)

3. Механічні параметри - характеризують стан робочого агрегату. До таких параметрів відносяться:

-хід регулюючого органу подачі пари (u1)

-хід регулюючого органу подачі крижаної води (u2)

-кількість пластин теплообмінника (n)

Параметрична схема технологічного процесу має змістовний характер. Формалізація опису взаємозв'язків між параметрами технологічного процесу досягається за рахунок переходу до формалізованої параметричної схеми технологічного процесу. При цьому ті параметри, які відображають цілі функціонування об'єкту моделювання і додаткові вимоги до нього, тобто ті параметри, які регламентовані, будуть вихідними, а параметри, що відображають умови функціонування об'єкту, - вхідними. 


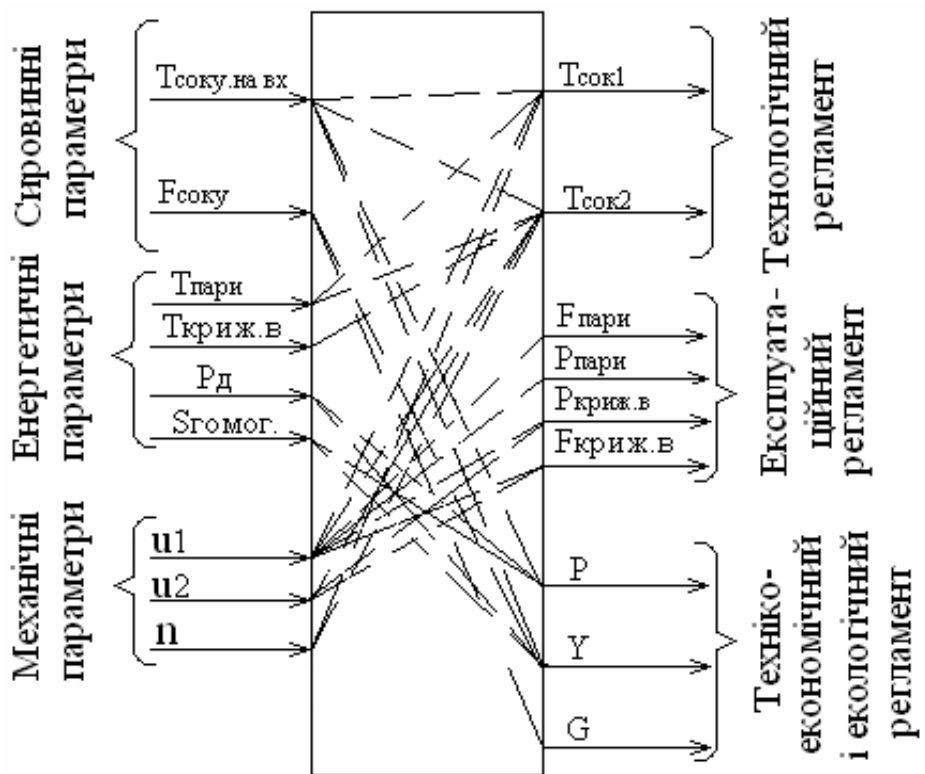

Рис. 3. Параметрична схема технологічного процесу пастеризації томатного соку

Формалізована параметрична схема технологічного процесу - це максимально важливий рівень формалізації опису технологічного процесу і найбільш узагальнена модель об'єкту управління. При переході від схем технологічного процесу до схем об'єкту управління змінюється термінологія. Поняття параметр змінюється на змінну або координату, а суть терміну параметр змінюється. Оскільки формалізована параметрична схема найповніше представляє опис технологічного процесу, то при подальшому опрацюванні деякими параметрами можна буде нехтувати, деякі ж, навпаки, гратимуть вирішальну роль. Отже, відбудеться спрощення схеми, що зробить ії зрозумілішою.

\section{Список використаних джерел:}

1. Минина О. М. Определение динамических характеристик и параметров типовых регулируемых объектов / О. М. Минина. - М: Академия наук СССР, 1963. - 48 с.

2. Новиков С. И. Практическая идентификация динамических объектов управления теплоэнергетического оборудования: Учеб. Пособие / С. И. Новиков. - Новосибирск: Изд-во НГТУ, 2004. - 64 с.

3. Ротач В. Я. Теория автоматического управления теплоэнергетическими процессами: Учебник для вузов / В. Я. Ротач - М.: Энергоатомиздание, 1985. - 296с.

Лазарєв Ярослав Олександрович, здобувач вищої освіти факультету комп'ютерних наук Національний технічний університет «Харківський національний університет радіоелектроніки», Украӥна

\section{МЕТОДИ АНАЛІЗУ МЕДІАКОНТЕНТУ В ІНФОРМАЦІЙНО- АНАЛІТИЧНИХ СИСТЕМАХ}

Інтернет простір розвивається 3 кожним днем. Ми живемо в інформаційному суспільстві. Тому разом з розвитком технологій змінюється і інформація. А точніше спосіб iii подачі. Якщо раніше інформація подавалася в текстовому і графічному вигляді, то тепер це неактуально. На перший план виходить оперативність, зручність використання інтернет ресурсів. Тому сьогодні існує таке поняття, як медіа контент. Це спосіб подачі інформації за допомогою медіа технологій, за коштами аудіо і відео. [1] 
На сьогоднішній день медіа контент включає в себе різні складові. Це відеоролики, аудіо файли, зображення, ігри. Такий вид контенту предствавляет інтерес для інтернетаудиторії. Тому його дуже вигідно використовувати для залучення інтернет-користувачів на різні ресурси. Дає можливість більш широко використовувати всі можливості інтернету.

Зараз якість інтернет-провайдерів набагато вище, ніж було раніше. Швидкість передачі і прийняття файлів займає лічені секунди. Тому для користування медіа контентом не виникає ніяких труднощів.

Також перевага такого виду контенту в тому, що більшість медіа файлів знаходяться у вільному доступі. Зараз не виникає труднощів з пошуком необхідної пісні, зображення плінтуса для стільниці з каменю, або того ж відеоролика про улюблених кішок.

Так як існує чимала кількість соціальних мереж, будь-який користувач може формувати свій власний медіа контент. Це можна створити в особистому профілі. Ви можете додавати туди медіа файли, взяті з інтернету, а так само ті, які знаходяться у вас на комп'ютері. Різні відеоролики, ігри, аудіо файли або зображення будуть знаходитися в вашому профілі. До них будуть мати вільний доступ усі користувачі. Хоча зараз з'явилася і така можливість, як обмеження доступу до медіа файлів на ваше особисте бажання.

Насправді, у аналізу немає свого характерного, специфічного або особливого методу, який використовувався $б$ саме для роботи 3 медіа. Прийнято використовувати міждисциплінарні методи, наприклад, такі як анкетування або контент-аналіз або методи «родинних» наук: соціології, психології, лінгвістики.

Перераховані далі методи можуть бути пов'язані між собою, що випливають одне 3 одного. [2]

1) Спостереження (польове)

Використовується спостереження в якісних медіа аналізах, як цілеспрямоване пасивне вивчення предметів. «В процесі ми отримуємо знання не тільки про зовнішні сторони об'єкта пізнання, а й про його істотні властивості і відносини». Важливим моментом спостереження є інтерпретація його результатів - розшифровка показань приладів і т.д.

2) Лабораторний експеримент

Лабораторний експеримент це активне i цілеспрямоване втручання у перебіг досліджуваного процесу, відповідну зміну досліджуваного об'єкта або його відтворення в спеціально створених i строго контрольованих умовах, що визначаються цілями експерименту.

3) Польовий експеримент

Його відмінність від лабораторного полягає лише в тому, що він проводиться в реальних умовах.

Плюс такого методу в тому, що ставлення або поведінку учасників експерименту вивчається не в штучних умовах лабораторії, а в реальних ситуаціях, що підвищує ймовірність того, що і поведінку максимально наближене до природного і справжньому. Обмеження в тому, що він дає менше можливостей для контролю, ніж лабораторний, однак, використання методів статистичного аналізу дозволило вченим домогтися більшої контрольованої сторонніх змінних.

4) Контент-аналіз

Контент-аналіз це один із способів кабінетного дослідження, який дозволяє виявити наявність, відсутність або кількість певних медіа повідомлень, які, імовірно, сприяють певних дій.

Переваги методу: можлива точна фіксація показників в об'ємних масивах емпіричних даних і їх надійність, мінімізація впливу суб'єктивного фактора (дослідника) на об'єкт. Недоліки: труднощі визначення набору категорій аналізу, велика трудомісткість процедури [6]. 
Інформаційно-аналіти́чна систе́ма (IAC) — це комп'ютерна система, яка дозволяє отримувати інформацію, створювати ії та здійснювати іiі обробку та аналіз [3].

Завданнями IAC є ефективне зберігання, обробка та аналіз даних.

Побудова IAC по суті своїй дуже дорогий і трудомісткий процес. Для того щоб уникнути таких проблем і забезпечити можливість проектування досить уніфікованих IAC, легко адаптуються до зміни зовнішніх умов, необхідна теоретична і методологічна база i відповідні інструментальні засоби її реалізації.

3 усіх методів найбільш детальним $є$ метод контент-аналізу.

Контент-аналіз - техніка укладання, виробленого завдяки об'єктивному i систематичному виявленню відповідних завданням дослідження характеристик тексту.

Головний недолік цього методу - це досить трудомістка процедура, він досліджує явно виражені параметри, а це істотно звужує пізнавальні можливості методу і фактично зводить його до опису.

Для вирішення цієї проблеми необхідно проводити більш детальний аналіз об’екта дослідження та враховувати неповерхневі фактори.

Висновки. Основна первага методу контент-аналізу в тому, що його можна застосовувати в умовах, при яких користувач може сам ввести інформацію, необхідну для аналізу i, отже, відсутня необхідність тривалого збору інформації.

Ще одна перевага даної системи в тому, що вона може бути застосована в інший предметної області. Для цього необхідно лише замінити або змінити відповідний контент. Це дозволить аналізувати різний контент.

\section{Список використаних джерел:}

1. Медіа-контент [Електронний ресурс] - Режим доступу: http://mp3fun.ru/news/300-media-kontent

2. Види та методи аналізу медіаконтенту [Електронний ресурс] - Режим доступу: http://www.dslib.net/zhurnalistika/informacionnyj-mediakontent-v-internete-sovremennaja-specifika-ikljuchevye.html

3. Жернакова О. Інформаційно-аналітичні системи Телемультімедіа, 2012. - 324 с.

Галагура Костянтин Антонович, здобувач вищої освіти факультету комп’ютерних наук Харківський національний університет радіоелектроніки, Україна

Науковий керівник: Хряпкін Олександр Володимирович, канд. технічних наук, доцент кафедри Системотехніки

Харківський національний університет радіоелектроніки, Украӥна

\section{ОСОБЛИВОСТІ І ПРОБЛЕМИ ДИСТАНЦІЙНОГО НАВЧАННЯ}

Зміни, що виникли у зв'язку з пандемією коронавірусу, торкнулися усіх сфер життя, зокрема і сфери освіти. На віддалену роботу перейшли школи, ліцеї, коледжі, університети. Освітній процес триває у дистанційному режимі.

У теперішній час існує безліч визначень дистанційного навчання. Одне 3 них, яке найбільш повно відображає суть цієї форми навчання засноване на матеріалах аналітичного звіту ЮНЕСКО 2000 року. Дистанційне навчання - форма навчання, при якій викладач і ті, що навчаються фізично розділені у часі i/або у просторі, і опосередкована застосуванням інформаційних технологій, використовуваних для подолання згаданої відстані зі збереженням показників якості навчання [1]. Кожна складова цього визначення містить 
певні особливості, які так чи інакше впливають на процес обміну інформацією зі здобувачами освіти. Проаналізуємо кожну з них детальніше.

Фізична віддаленість викладача і його слухачів може негативно вливати на ефективність сприйняття і засвоєння знань через відсутність очного контакту осіб. При цьому втрачається емоційне забарвлення, що є досить важливим аспектом у навчанні будького, зникає живе обговорення матеріалу студентами, можливість моментально отримати відповідь на питання, а контроль прозорості виконання тестових завдань та ідентифікація студента ускладнюються.

Дистанційне навчання передбачає використання сучасних інформаційних технологій. Саме через це не для всіх представників освіти зміна формату роботи виявилася нелегким завданням. Технологічно підковані викладачі використовують засоби віддаленого конференц-зв'язку, попит на які нині досяг піку. Вчителям середнього та похилого віку, які з комп'ютером завжди були на «ви», важко дається освоєння нових технологій, тому все частіше можна почути від батьків, що у кращому випадку дистанційне навчання в період карантину обмежується відправленням домашнього завдання за допомогою месенджерів.

Крім того, для роботи навіть найбільш проривних напрацювань у сфері інформаційних технологій потрібен електричний струм та стабільне інтернет-з'єднання, котрі іноді можуть бути відсутніми, особливо в приміській місцевості.

Дуже серйозною проблемою дистанційного навчання $є$ переосмислення використання багатьох перевірених педагогічних прийомів для кращого запам'ятовування і засвоєння матеріалу. Застосування самих різних педагогічних методів стає більшою мірою залежним від технічних засобів і способів організації контакту з учнями. Однак необхідно відзначити, що при будь-якій технології взаємодії викладачеві доводиться вчитися більш стисло і чітко викладати матеріал або відповідати на питання. I в даній ситуації стає концептуальним постійне і безперервне самовдосконалення як викладача, так і того, хто навчається [2].

У підсумку можна сказати, що дистанційне навчання як явище науково-технічного прогресу має право на життя у майбутньому за умови створення методів вирішення зазначених проблем та забезпечення такого рівня якості освіти, який би не поступався традиційному.

\section{Список використаних джерел:}

1. Гаєвська Є. Г. (2007). Технології мережевого дистанційного навчання. Санкт-Петербург: Ф-т філології та мистецтв СПбДУ.

2. Сагіндикова А.С. \& Тугамбекова М.А. (2015). Актуальність дистанційної освіти. Молодий вчений, (20), 495-498. Вилучено 3: https://moluch.ru/archive/100/20703/. 
Малітчук Андрій Дмитрович, здобувач вищої освіти факультету Інженерії програмного забезпечення Івано-Франківський національний технічний університет нафти і газу, Украӥна

\section{ПЕРЕВАГИ ЗАСТОСУВАННЯ МІКРОСЕРВІСНӦ̈ АРХІТЕКТУРИ ПРИ ПОБУДОВІ РОЗПОДІЛЕНИХ СИСТЕМ}

На данний момент, найпоширенішим архітектурним принципом побудови розподілених систем $\epsilon$ клієнт-серверна архітектура. В якості сервера виступає програмний засіб чи система, яка надає контрольований, регламентований доступ до даних чи обчислюваної потужності кінцевому користувачу. Серверна частина може бути двох типів: монолітна і мікросервісна [1]. На момент написання статті широку популярність набули саме мікросервіси, які широко впроваджують в системах, які необхідно розширювати 3 часом і вносити часті поправки.

Мікросервіс - архітектурний стиль, згідно якого система будується як множина сервісів, кожен з яких працює у власному середовищі, має свою базу даних, виконує, здебільшого, одну визначену функцію згідно бізнес-логіки і взаємодіє 3 рештою мікросервісів за допомогою повідомлень та брокера; зазвичай, в якості протоколу передачі використовують НТТР [2]. Серед очевидних переваг, виходячи з визначення, це можливість реалізації мікросервісів різними засобами (мовами програмування, фреймворками, тощо) головна вимога, яка ставиться до розробників - реалізація поставленого завдання та регламентований спосіб та вид передачі повідомлень між компонентами цілісної системи.

До основних властивостей мікросервісної архітектури можна віднести:

- незалежність розробки - різні команди можуть вести розробку незалежно, 3 мінімальним контролем за інтеграцієб та взаємодією;

- використання реалізованих мікросервісів як компоненти повторного використання до прикладу, добре задокументований та відлагоджений мікросервіс, який виконує конвертацію валют можна використати майже у всіх фінансових проектах;

- легкість внесення змін - коли, до прикладу, в моноліті необіхдно виконати зміну якоїсь іï складової, система, вірогідно, буде зупинена і ймовірні випадки, коли внесення змін у один компонент понесе зміни до інших; у випідку з мікросервісами завдяки слабкій зв'язуваності система, ймовірно, може працювати далі навіть без одного 3 компонентів (якщо він не критичний) і пов'язані зміни будуть малоймовірними;

- ефективність викоритання ресурсів технічного обладнання - завдяки розподіленості i варіативності реалізваного функціоналу, мікросервіси можуть бути розгорнуті на пристроях з обмеженими ресурсами, які відповідають дійсному навантаженню на вузол;

- висока стійкість - у випадку, якщо один з мікросервісів вийде, у зв'язку з деякими причинами зладу, система може функціонувати далі; повертаючись до попереднього прикладу, якщо вийшов зладу мікросервіс який виконував конвертацію валют, банківська система (наприклад) може функціонувати далі і виконувати всі операції, які не пов'язані 3 іноземною валютою.

Таким чином [3], у випадку, якщо для проекту необхідно забезпечити швидке розгортання, часте внесення змін та розширення функціональних можливостей і розробка ведеться 3 нуля - вірогідним вибором буде мікросервісна архітектура; якщо ж вже існує моноліт, то складність декомпозиція системи на окремі мікросервіси та їхня реалізація, ймовірно, перекреслить більшість переваг отриманих від мікросервісів.

\section{Список використаних джерел:}

1. Jamshidi, P.; Pahl, C.; Mendonça, N. C.; Lewis, J.; Tilkov, S. (May 2018). Microservices: The Journey So Far and Challenges Ahead. IEEE Software. 
2. Newman, Sam (2015-02-20). Building Microservices. O'Reilly Media. ISBN 978-1491950357.

3. Nadareishvili, I., Mitra, R., McLarty, M., Amundsen, M. (2016) Microservice Architecture: Aligning Principles, Practices, and Culture, O’Reilly.

DOI 10.36074/29.05.2020.v2.01

Козловський Павло-Вадим Юрійович, студент групи КН-214 Інституту комп’ютерних наук та інформаційних технологій Національний університет «Львівська політехніка», Україна

\section{ПРОГРАМУВАННЯ ДРОНІВ НА ОСНОВІ НЕЙРОННИХ МЕРЕЖ ДЛЯ ВИЯВЛЕННЯ ПОЖЕЖ НА РАННІЙ СТАДІЇ}

Дрони - це безпілотні літальні апарати, які виконують здебільшого розвідувальну функцію. Вони можуть рухатися в небезпечних для людини умовах і достатньо автономні, щоб довший час залишатися без енергетичної підтримки. Застосування дронів надзвичайно різноманітні, їх використовують для військових цілей, журналістики, пошуку жертв в місцях катастрофи, забезпечення безпеки, доставки вантажів тощо.

У майбутньому дрони зможуть виконувати багато корисних функцій: моніторинг погодних умов і території, перенесення вантажів, ведення бойових дій без участі людей тощо.

У нашому дослідженні ми шляхом навчання нейронних мереж та написання відповідних програм проектуємо дрони для виявлення пожеж на ранній стадії.

Як правило, більшість дронів реагують на дим і пожежу тоді, коли вона вже охоплює доволі значну територію. Тоді дрон сповіщає координати горіння, а у низці випадків долучається до гасіння пожежі.

Зазвичай дрон працює на акумуляторній батареї, що дозволяє йому триматися в повітрі. Його лопаті, аналогічно до вертолітних, дозволяють йому підніматися і літати.

Сучасні дрони оснащуються камерами для спостереження чи зйомки, а також знаряддями, необхідними для виконання конкретного завдання. Загалом дрони керуються дистанційно, а деякі з них оснащуються автопілотними системами, що дозволяє дрону повернутися на місце, звідки він стартував.

Однак, можливості дронів поки обмежені (радіус зв'язку з пультом управління, точність сенсорів, тривалістю заряду батареї тощо).

Для лісового господарства у всьому світі щораз більшого значення набуває використання дронів для патрулювання лісів у періоди високої пожежної небезпеки. Вартість такого патрулювання у п'ять і більше разів нижча порівняно із використанням традиційних гелікоптерів або легкомоторних літаків.

Нині для виявлення лісових пожеж дрони досить широко використовуються у лісовому господарстві Австралії, Канади, Польщі та інших країнах. Наприклад, у Китаї розробили дрон для гасіння пожеж, однак цей пристрій більше схожий на вертоліт і має декілька метрів у довжину.

В Україні на даний час виробляється понад десять типів безпілотних літальних апаратів, з яких п'ять $€$ перспективними для використання у лісовому господарстві України, як недорогий і ефективний засіб виявлення лісових пожеж. Оператор, спостерігаючи за зображеннями, що передаються 3 безпілотника в режимі реального часу, може контролювати параметри польоту, а помітивши дим, переводить режим польоту до ручного чи напівавтоматичного управління, та спрямовує його до місця виявлення диму.

Документування лісових пожеж виконується за допомогою фотоапарата або відеокамери (стоп-кадр). Загальний огляд лісових пожеж доцільно виконувати 3 висоти 
польоту безпілотника 600-800 м з нанесенням на карту меж пожежі, напрямку поширення вогню, місцезнаходження людей і техніки, правильності їх розстановки на крайці пожежі тощо. Контроль за роботою лісопожежних служб краще виконувати з висоти 200-400 м, 3 якої будуть добре проглядатись мінералізовані смуги, квартальні просіки, лісові дороги тощо.

Для виявлення прихованих осередків горіння безпілотниками, необхідно застосовувати оптичний та інфрачервоний діапазони у вранішні та вечірні години, коли вплив сонячної радіації є мінімальним.

Іншим варіантом є використання іноземних відносно недорогих квадрокоптерів, які оснащені камерами, GPS і акумуляторними батареями: DJI Inspire 1 або DJI Phantom 3 Professional.

У нашому проекті дрон реагує на невеликі вогнища, зокрема такі, які передують охопленню території суцільною пожежею. Тобто, дрон здатний зафіксувати локальні зародки пожежі, окремі спалахи та місця загорання. Яскравим прикладом такої потенційної пожежі на ранній стадії є самозагорання луків торфовищ, які охоплюють великі території.

Розроблений нами дрон працює на основі нейронних мереж, тож основним завданням $\epsilon$ навчання мережі розпізнавати вогонь (розробка відповідної програми) та обладнання дрона камерою спостереження. Літальний апарат може вести спостереження в місцях важко доступних або таких, що їх неможливо спостерігати з землі.

Такий дрон дозволяє зафіксувати пожежу на їі ранній стадії і вчасно погасити вогонь, доки пожежа не стала масштабною і небезпечною.

Водночас, маючи невеликі розміри, такий дрон не буде надто дорогим.

Зауважимо, що важливим аспектом роботи таких дронів на певній території $\epsilon$ неперервність їх патрулювання: доки літатиме один дрон, у пожежній частині індикатори показують його заряд. Коли заряд буде недостатнім, то дрон повертається назад, а інший відразу вилітатиме на цю ж територію. Контролюючи певну територію, дрон постійно передає відомості про наявність вогню, сигнал терміново передається в пожежну частину і працівники виїжджають на місце пожежі.

\section{Список використаних джерел:}

1. Андрієнко М.В. Сфера пожежної безпеки в Україні: проблемні питання державного управління: Черкаси, 2015.

2. Руснак І.С. Безпілотна авіація у сфері цивільного захисту України. Стан і перспективи розробки та застосування. Наука і оборона. 2014. №2.

3. Чумаченко С.M. Аналіз ефективності застосування безпілотної авіації в надзвичайних ситуаціях агропромислового комплексу України- [Електронний ресурс]. - Режим доступу: http://irbisnbuv.gov.ua/cgibin/irbis_nbuv/cgiirbis_64.exe?C21CO. 
Голтвянська Катерина Олегівна, здобувач вищої освіти факультету прикладної математики

Дніпровський національний університет імені Олеся Гончара, Україна

Науковий керівник: Білобородько Оксана Іванівна, канд. техн. наук, доцент

кафедри математичного забезпечення ЕОМ

Дніпровський нащіональний університет імені Олеся Гончара, Украйна

\section{РОЗРОБКА ПРОГРАМНОГО ЗАБЕЗПЕЧЕННЯ РОЗБИТТЯ ЗОБРАЖЕННЯ НА ФРАГМЕНТИ ЗАСОБАМИ КОНТУРНОГО АНАЛІЗУ}

В наш час, в інформаційну еру, часто виникає потреба аналізувати зображення. Робити це можна по-різному, наприклад, виконавши сегментацію, детекцію або ж розбиття зображення на окремі складові за контурами. Всі ці процеси виконуються за допомогою методів контурного аналізу.

Загалом, контурний аналіз - це сукупність методів знаходження і опису контурів зображення для подальшого його розпізнавання. В даному випадку під контуром об'єкта розуміють певну межу, яка відділяє його від інших об’єктів. Зазвичай контур повністю визначає форму об'єкта, тому дуже часто контурний аналіз використовується саме для розпізнавання об'єктів на зображенні за формою. Слід зазначити, що методи контурного аналізу не беруть до уваги внутрішні точки об'єкта на зображенні, цей факт дозволяє зменшити об'єм інформації, яка опрацьовується під час аналізу зображення.

Розпізнавання контурів дозволяє змінювати об’єкт шляхом масштабування, зміни кута нахилу або переносу об'єкта. Однак розпізнати можливо не всі контури. Межі об'єкта можуть бути розпізнані некоректно або ж взагалі невірно якщо:

- зображення $\epsilon$ нечітким і його контури розмиті;

- на зображенні присутні різні дефекти у вигляді зайвих точок, штрихів (це так звані помилкові контури);

- об'єкт має занадто широкі контурні лінії.

Існує багато методів розпізнавання контурів, серед них найбільш відомими вважаються: детектор меж Кенні, метод Сатоші Сузукі, кластеризація, методи активних контурів, метод локальної обробки, метод відслідковування контурів і аналіз графами [1]. Спільним для всіх зазначених методів $є$ кодування контуру. В контурному аналізі межа об’єкта кодується у вигляді вектора комплексних чисел. Для кодування на контурі навмання обирається точка відліку (початкова точка), вона має бути фіксованою. Далі, під час руху по контуру, визначається вектор зсуву у вигляді комплексного числа (1):

$$
\vec{v}=a+i b
$$

де: $a$ - ие зсув нової точки відносно попередньої по осі $x$,

$b$ - ие зсув нової точки відносно попередньої по осі $y$.

Варто зазначити, що рух по контуру може відбуватися як за годинниковою стрілкою, так і в протилежну сторону (рис. 1) [2].

Контурний аналіз не втрачає своєї актуальності в проблемі розпізнавання об'єктів навіть в наше сьогодення, коли з'являються новіші, більш продуктивніші способи аналізу зображень. Зараз методи контурного аналізу активно використовуються в різноманітних програмах розпізнавання тексту на зображенні або ж розпізнавання об'єктів на відео, останне запроваджено в системі безпеки автомобілів, системі місцевого відеоспостереження тощо. 


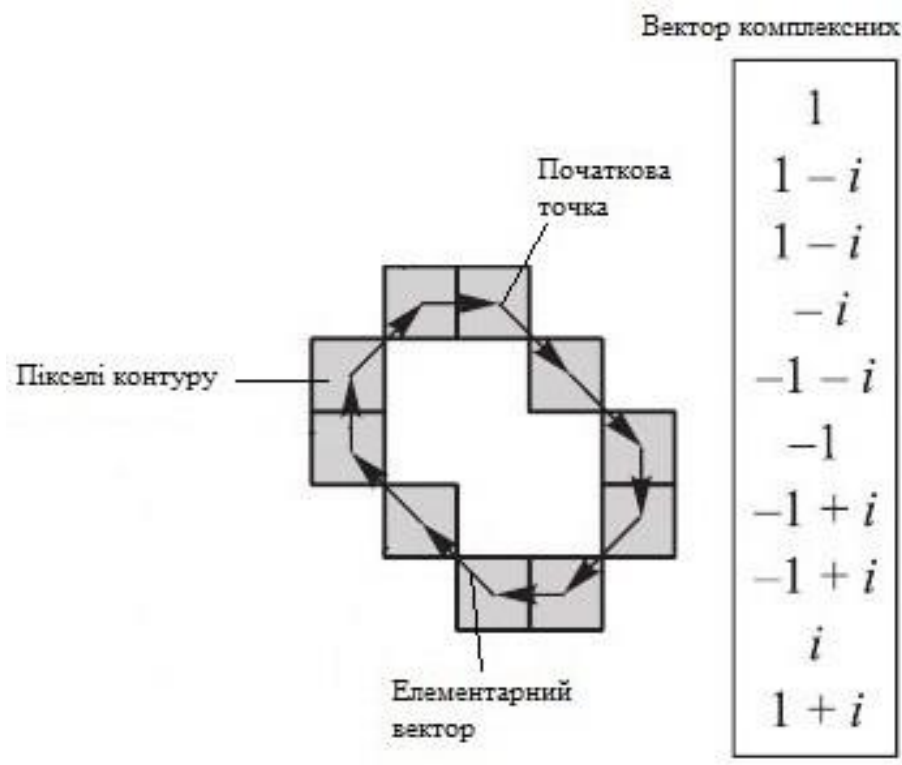

Рис 1. Кодування контуру

Моєю метою було створити програмне забезпечення, яке могло б використовуватись на швейних підприємствах або схожих закладах, з метою автоматизації та прискорення виробництва. Головна ідея даної програми полягає в тому, щоб приміряти на ескізи одягу різні кольорові гами тканин, а також видозмінювати ці ескізи по деталях. Для реалізації цієї задумки потрібно розбити зображення (ескіз) на об’єкти (деталі), для цього використовуються засоби контурного аналізу, зокрема, метод Сатоші Сузукі. Користувач має змогу завантажити власний ескіз, розбити його на деталі одягу, а потім до кожної з них приміряти різний колір чи візерунок тканини та подивитися на всю композицію загалом (рис. 2). Окрім цього програма передбачає можливість завантаження двох ескізів для заміни певних деталей одягу одного з них на вибрані деталі одягу іншого. Готові ескізи можна зберегти в пам'яті комп'ютера. Програмне забезпечення було створено за допомогою мови програмування C\# з використанням бібліотеки EmguCV, яка реалізує методи контурного аналізу.

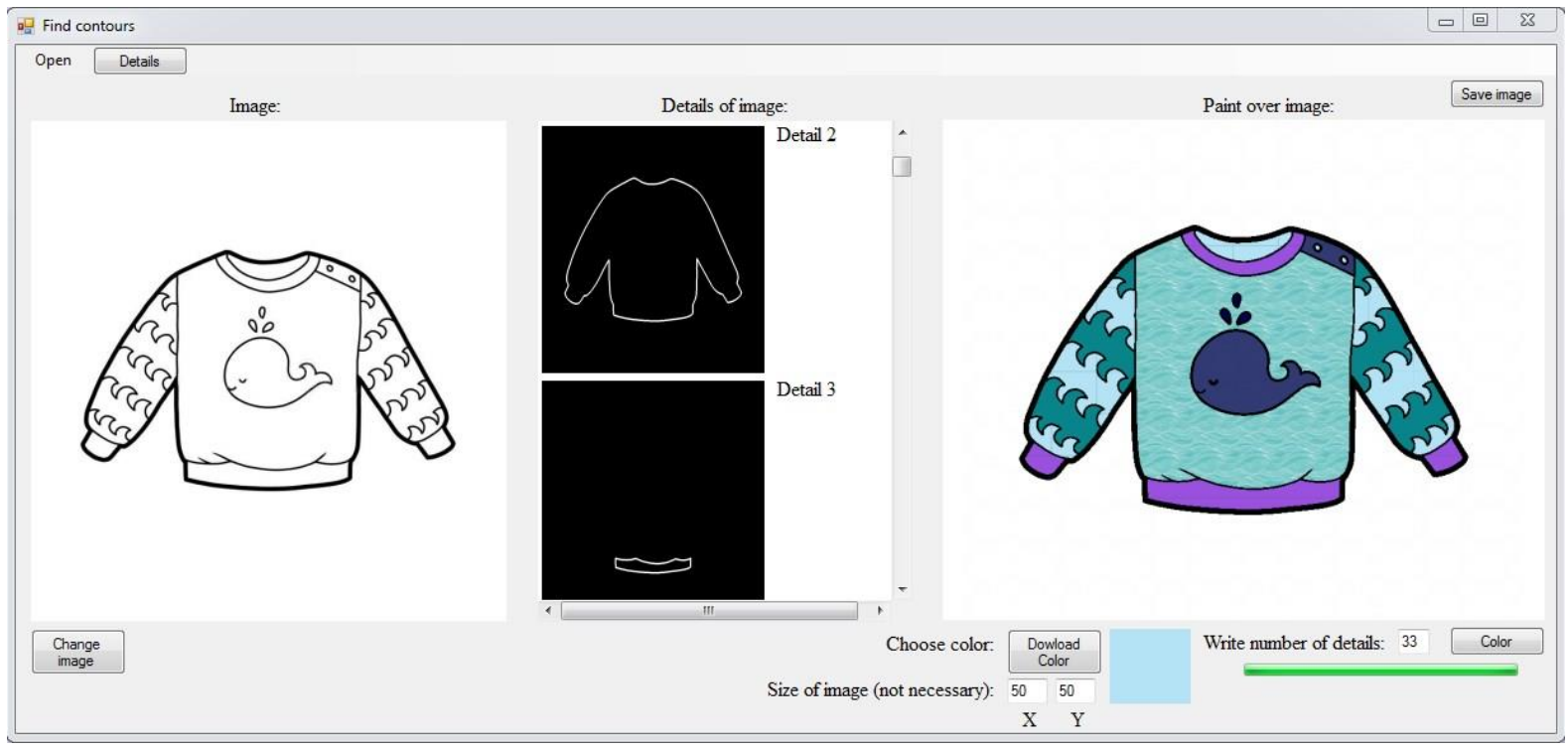

Рис 2. Робота з програмою 


\section{Список використаних джерел:}

1. Сакович И.О. \& Белов Ю.С. (2014) Обзор основных методов контурного анализа для выделения контуров движущихся объектов. Инженерный журнал: наука и инновации, (12), 2-6. Вилучено з: http://engjournal.ru/catalog/it/hidden/1280.html.

2. Чудовская А.К. (2010) Возможности распараллеливания алгоритмов выделения контура по технологи CUDA. Сборник докладов IV Международной научно-практической конференции «Современная информационная Украина: информатика, экономика, философия», 67-70.

Лічман Едуард Русланович, здобувач вищої освіти факультету інформаційних технологій та комп'ютерної інженерії Вінницький національний технічний університет, Украӥна

Науковий керівник: Рейда Олександр Миколайович, кан. техн. наук, доцент кафедри програмного забезпечення Вінницький національний технічний університет, Украӥна

\section{РОЗРОБКА ІНТЕРАКТИВНИХ ВЕБ-ДОДАТКІВ}

Сьогодні все більша і більша кількість вітчизняних і зарубіжних компаній виявляють інтерес до бізнесу в Інтернеті. Причина цього - можливість пропонувати товари та послуги по всьому світу, не витрачаючи на це величезні фінансові кошти. Саме тому така область програмної індустрії, як створення веб-додатків, набуває сьогодні особливого значення.

Найбільш поширені області застосування веб-додатків - це Інтернет-магазини, біржі, електронні конференції (дошки оголошень), системи спілкування в реальному часі, призначені для обміну інформацією між користувачами Інтернету.

За архітектурою і принципам роботи веб-додатки помітно відрізняються від звичайних програм, що працюють на ПК, робочих станціях або серверах локальної мережі. Крім того, що веб-додатки завжди повинні працювати в багато потоковому i багатокористувацькому режимі, при їх розробці необхідно також враховувати ненадійність каналів передачі даних Інтернету, а також відносно невисоку в середньому швидкість передачі даних по таким каналам.

Етапи створення веб-додатку. Хоча створення найпростіших веб-серверів і домашніх веб-сторінок доступно багатьом, розробка веб-додатків - непросте завдання. Якщо для створення звичайного застосування досить якого-небудь одного інструментального засобу, то веб-програмісту набагато важче: йому доводиться мати справу з багатьма, часом не цілком сумісними між собою технологіями [1].

Розробка проекту Створення нового веб-додатки необхідно починати з розробки проекту. На цьому етапі слід з'ясувати, що ж, власне, потрібно зробити і яким саме чином. Хоча етап розробки проекту зазвичай виконується в тісній взаємодії з замовником, далеко не завжди замовник уявляє собі можливості Інтернет-технологій і свої реальні потреби.

Розробка дизайну. Дизайн визначає зовнішній вигляд програми, в якому воно постане перед користувачами. Можливо, у замовника вже $є$ розроблений раніше фірмовий стиль. Розробка хорошого дизайну під силу тільки фахівцеві, що володіє не тільки художнім смаком, але і навичками роботи 3 комп'ютерними інструментами, призначеними для створення веб-сторінок, зображень і анімації [2]. Деякі обмеження веб-додатків, змушують вдаватися до спеціальних прийомів, що дозволяє, зокрема, зменшити розмір файлів 3 малюнками і анімацією.

Налаштування процедур обслуговування. Після запуску веб-додатку, необхідно налаштувати такі процедури обслуговування, як резервне копіювання даних, що 
зберігаються в СУБД, і файлів веб-сервера, розсилка новин по електронній пошті, фонова статистична обробка бази даних, автоматичне відстеження працездатності веб-сервера.

Тестування і дослідна експлуатація. Відомо, що будь-яка більш-менш складна програма містить помилки. Виникаючі в них помилки можуть носити випадковий характер або проявлятися тільки при високій завантаженості веб-сервера. Тому потрібно бути готовим до того, що найбільш підступні помилки з'являться вже після введення системи в експлуатацію. Наявність етапу дослідної експлуатації обов'язково, і чим більша кількість людей прийме в ньому участь, тим краще.

Висновки. Існує безліч засобів для створення інтерактивних веб-додатків, але лише деякі з них здатні надати розробникам інструменти для вирішення переважної більшості завдань. При проектуванні та розробці веб-інтерактивного додатку для оптимального пошуку і аналізу інформації про підприємства громадського харчування буде використано найбільш актуальні методи та технології.

\section{Список використаних джерел:}

1. Борисенко A.A. Web-дизайн. Просто як двічі два. - М .: Ексмо, 2008.- 320 с.

2. Інькова Н. А., Зайцева Е. А., Кузьміна Н. В., Толстих С. Г. Створення Web-сайтів: Навчально-методичний посібник. Ч. 5. Тамбов: Вид-во Тамбо. держ. техн. ун-ту, 2005. - 56 с.

Мараренко Владислав Олександрович, студент

Одеський національний політехнічний університет, Украйна

Науковий керівник: Бобріков Сергій Олександрович, доц., канд. техн. наук

Одеський національний політехнічний університет, Украйна

\section{РОЗРОБКА РЕГУЛЯТОРА НАЛАШТУВАННЯ КОТУШКИ В РЕЗОНАНС 3 ЄМНICТЮ МЕРЕЖI НА БАЗІ МІКРОПРОЦЕСОРА}

На сьогоднішній день на ринку з'явилася елементна база, що дозволяє створювати сучасні недорогі системи управління дугогасними котушками, що задовольняють потреби сьогоднішнього дня. Нову елементну базу для побудови систем управління дугогасною котушкою запропонувала фірма MOTOROLA, що є найбільшим постачальником високо продуктивних мікроконтролерів з вбудованими можливостями управління котушками. Фірма MOTOROLA запропонувала споживачам сімейство мікроконтролерів 68300, призначене для ефективного управління сучасними котушками.

Мікроконтролер МС68333 є функціональним розширенням моделі МС68332, який в свою чергу послужив базовою моделлю, на основі якої реалізований ряд наступних моделей. Одержав широке поширення в робототехніці, автомобільній електроніці, пристроях управління електродвигунами, системах промислової автоматики. До нього були додані ППЗУ (Flash) ємністю 64 Кбайт, 10-розрядний АЦП с 8 аналоговими входами, ОЗУ таймерного процесора ємністю 3,5 Кбайт. Розроблений спочатку для систем керування автомобільними двигунами, цей мікроконтролер у даний час знаходить також широке застосування в складнофункціональній промисловій автоматиці і зв'язковий апаратурі. Приклад роботи алгоритму мікроконтролера можна побачити на рисунку 1. 


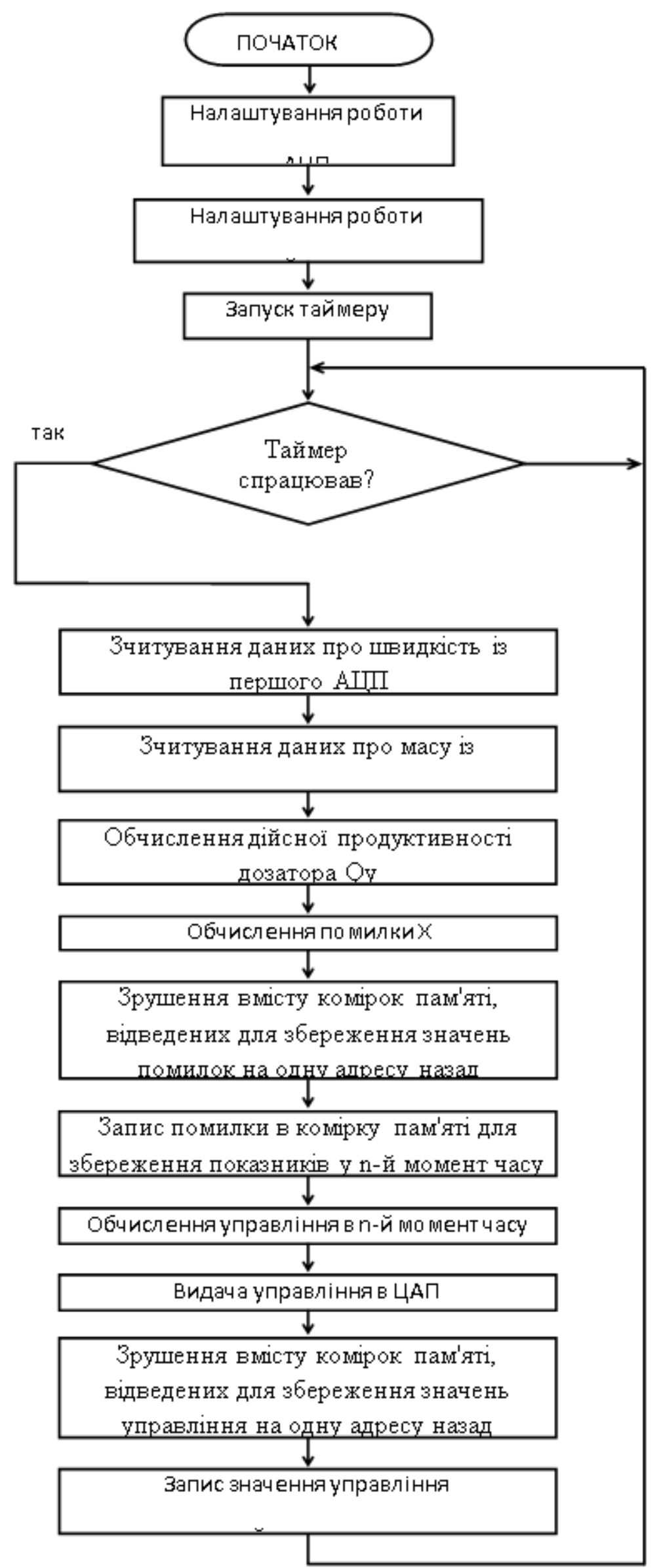

Рис. 1. Блок-схема алгоритму роботи мікроконтролера 
При написанні програми задамося наступними положеннями: при роботі АЦП у регістрі першого АЦП знаходяться значення напруги мережі, а в регістрі другого АЦП значення індуктивного опору котушки, у комірках пам'яті починаючи 3 осередку А0 розташовані чотирьохбайтні значення елементів рекурентного рівняння для помилки, у комірках пам'яті починаючи 3 осередку A1 - чотирьохбайтні значення елементів рекурентного рівняння для управління. Даний контролер при звертанні до зовнішніх пристроїв використовує керуючі сигнали для звертання до пам'яті, тому будемо считати, що за адресою А3 знаходиться пристрій, прочитавши дані з який ми одержимо необхідну продуктивність, а для висновку керуючих сигналів нам необхідно зробити їхній запис у пристрій за адресою А4. Символ * в адресному полі позначає значення власне для кожного 3 типів мікроконтролерів сімейства 63800.Текст програми подано у таблиці 1.

Текст основної програми

\begin{tabular}{|c|c|c|c|}
\hline № & Мітка & Команда & Пояснення \\
\hline 1 & & MOVE.W \#\$0000, $\$ *$ FF700 & Запис управляющих слів АЦП. Задається \\
\hline 2 & & MOVE.W \#\$00FF, \$*FF70A & режим роботы $310-m u$ \\
\hline 3 & & MOVE.W \#\$00C0, \$*FF70C & розрядним результатом перетворення. \\
\hline 4 & & MOVE.W \#\$011C, \$***E0C & Налаштування таймеру на звичайний режим. \\
\hline 5 & & MOVE.W \#\$0720, \$***E08 & Формування сигналу з ладанною затримкою. \\
\hline 6 & & MOVE.W \#\$6083, \$***E08 & Запуск роботи таймеру. \\
\hline 7 & M1 & NOP & Відсутність операції. \\
\hline 8 & & JMP M1 & Безумовний перехід на М1. \\
\hline
\end{tabular}

Обраний мікроконтролер найбільш оптимально підходить для управління автоматичним регулятором налаштування котушки дугогасіння в компенсованих електромережах.

\section{Список використаних джерел:}

1. Сомов, В.А. О возможности работы дроселя насыщения без искажения формы кривой регулируемого тока / В.А. Сомов, В.В.Шуть, С.А.Бобриков // Электромеханика . - известия ВУЗов. - 1962. - №8.

2. Сомов, В.А. Дугогасящая катушка с плавным регулированием / В.А. Сомов, В.В. Шуть, С.А.Бобриков // Электричество . - Энергия. - 1965. - №5.

3. Сомов, В.А. К рас чету дугогасящей кактушки, регулируемой подмагничиванием / В.А. Сомов, В.В. Шуть, С.А. Бобриков //Электромашиностроение и электрооборудование. - Харьков. -1967. - №6.

Самойленко Егор Алексеевич, получатель высшего образования факультета компьютерной инженерии Харьковский национальный университет радиоэлектроники, Украина

Шморгай Екатерина Олеговна, получатель высшего образования факультета компьютерной инженерии

Харьковский национальный университет радиоэлектроники, Украина

\section{СРАВНЕНИЕ МЕТОДОВ СТЕГАНОГРАФИИ В ИЗОБРАЖЕНИЯХ}

Назначение компьютерной безопасности состоит в защите информации от несанкционированного доступа, случайного или целенаправленного искажения данных без изменения основных свойств файлов. Криптография создавалась как методика для защиты систем связи методами кодирования и последующей расшифровки данных. Стеганография 
дополняет криптографию, скрывая сам факт наличия сообщения в передаваемом потоке данных. Стеганографию можно рассматривать как создание скрытого канала связи.

Скрытое сообщение можно инкапсулировать практически во все виды данных. Большинство инструментов стеганографии ориентируется на передачу сообщения в Интернете, где значительная часть информации передается в виде изображений. При обработке изображения- контейнера учитывают формат файла, в частности методы сжатия. От этого зависят как методы инкапсуляции, так и объем стеганограммы, которую можно вставить в файл. Сложность процедур стеганографии также зависит от формата контейнера.

\section{І.Классификация методов стеганографии для изображений-контейнеров}

Для временной области основные процедуры инкапсулируют скрытое сообщение в младшие биты цифрового кода пикселов изображения. Для частотных процедур стеганограмма вставляется в частотную характеристику изображения. Временные процедуры включают следующие методы:

- внедрение цифрового кода сообщения в изображение;

- статистические методы замены: бит изображения заменяется по некоторому статистическому закону;

- частотные процедуры состоят в замене малозначащих частотных характеристик изображения.

Каждый стеганографичекий метод обладает как сильными, так и слабыми сторонами. Пользователю важно выбрать метод, который в наибольшей степени соответствует поставленной задаче. Все алгоритмы стеганографии должны удовлетворять нескольким основным требованиям. Наиболее важно, чтобы алгоритм давал малозаметное изменение изображения-контейнера. Рассмотрим критерии сравнения:

- незаметность или уровень восприятия (нез.). Это главное требование стеганограмма не должна распознаваться глазом человека. Человек не должен видеть различие между исходным изображением и тем же изображением со вставленным сообщением;

- вместимость (вмест.). Это требование определяет размер вставляемого сообщения, который зависит от формата контейнера;

- робастность. Вставляемое сообщение не должно быть повреждено процессами обработки и передачи, присущими данному формату. Существует два типа робастности:

- робастность для защиты от статистической атаки (РПСА). Статистические тесты применяются для выявления наличия стеганограммы в контейнере, это методы статистической обработки данных, которые можно применять как во временной, так и в частотной области;

- робастность для защиты от целенаправленного повреждения стеганограммы (РПЦП). Этот вид робастности обусловлен тем, насколько скрытое сообщение зависит от контейнера;

- способность к обнаружению или скрытность (СОС). Этот критерий определяет успешность метода скрытия, при распознавании наличия сообщения он обусловливает сложность алгоритма распознавания;

- вид области (BО). Этот параметр указывает на область, в которой применялась стеганография - временная (В) или частотная (Ч);

- независимость от формата (НФ). Следует использовать различные форматы файлов. Если партнеры постоянно используют один формат, то это может навести на мысль о тайной переписке.

В идеальном случае стеганографический алгоритм должен удовлетворять высоким уровням всех критериев. Необходим взвешенный выбор стеганографического метода, 
который зависит от используемого пользователем приложения. Рассмотрим пригодность различных алгоритмов для форматов файлов:

LSB для BMP. Растровый формат BMP не использует сжатия, поэтому файлы этого формата имеют большой объем. Но для сокрытия сообщения в этих файлах необходим очень большой контейнер.

LSB для JPEG. Распространенный формат JPEG использует 8 битов на каждый цвет RGB. JPEG может скрыть сообщение большого объема.

LSB для цветовой палитры. Формат GIF кодирует пиксел 8 битами, изображение записывается в 256 цветах. Алгоритм LSB скрывает информацию с различными степенями успеха в зависимости от доли изменяемых бит. Необходимо искать равновесие между безопасностью и распознаваемостью

Псевдослучайные перестановки. Метод вставляет биты сообщения с изменением порядка их появления в сообщении, что затрудняет работу по обнаружению и расшифровке сообщения.

Метод с использованием патчей. Недостаток этого метода состоит в том, что в один патч инкапсулируется только один бит. Преимущество этого метода состоит в том, что сообщение распределено по всему изображению, и если один из патчей будет поврежден, то это не принесет больших потерь и сообщение можно восстановить из других патчей.

Метод расширения спектра. Этот метод распределяет сообщение по всему изображению. Такую стеганограмму трудно распознать. Частотная характеристика сообщения обладает гораздо меньшей энергией, чем энергия контейнера. Этот метод имеет большую робастность против атак.

Дискретное косинус-преобразование. Методы области преобразования (частотной области) скрывают сообщение в значительной области изображения, что делает их более робастными по сравнению с методами во временной области, включая сжатие, обрезку и некоторые алгоритмы обработки изображений.

Дискретное вейвлет-преобразование. Инкапсуляция сообщения с помощью ДВП дает хорошие результаты, которые превосходят методы ДКП. Многомасштабный вейвлетный анализ разлагает сигнал в узкие частотные области, что позволяет скрыть сообщение в мелких деталях изображения.

Основные методы стеганографии приведены на рис. 1:

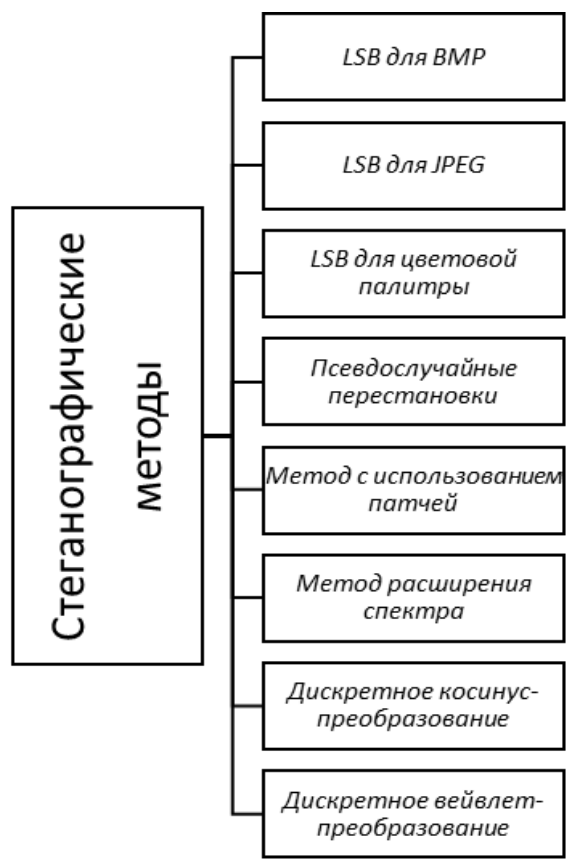

Рис. 1. Стеганографические методы 
Bывод. В статье были рассмотрены некоторые из основных методов стеганографии изображений. Все основные форматы графических файлов имеют различные методы сокрытия сообщений со своими сильными и слабыми сторонами. Выбор метода с большой надежностью противостоит методу с высокой скоростью обработки. Например, патчподход имеет очень высокую устойчивость по отношению к большинству видов атак, но он может скрыть лишь очень небольшое количество информации. Поэтому более разумно скрывать информацию в дополнительных преобразованиях, а не в исходных файлах. Преобразование дискретными вейвлетами более надежно, потому что позволяет скрыть сообщение в области частот. Данная область менее подвержена зрению человека.

\section{Список использованных источников:}

1. Кюрие Д. (1996). преодоление влияния сжатия с потерями на стеганографию.

2. Ахсан, К. (2002). Практические данные прячутся в ТCP/IP. Материалы семинара по безопасности мультимедиа в АСММ Канада.

3. Джонсон Н. (1998). Изучение стеганографии: Видеть Невидимое. Компьютерный журнал.

4. Моркел Т. (2002). Обзор стеганографии изображения.

5. Маскур Х. (2008). Новая техника стеганографии имиджа.

Сорока Сергій Юрійович, здобувач вищої освіти факультету інформаційних технологій та комп'ютерної інженерії

Вінницький національний технічний університет, Украйна

Науковий керівник: Коваленко Олена Олексіївна, кан. техн. наук, доцент кафедри програмного забезпечення

Вінницький національний технічний університет, Украйна

\section{СУЧАСНІ СИСТЕМИ УПРАВЛІННЯ НАВЧАННЯМ}

Питання автоматизованого управління плануванням i організацією освітнього процесу завжди стояли в центрі уваги керівництва передових вищих навчальних закладів, ïx навчальних відділів та управлінь, факультетів і великих кафедр. Стратегія розвитку електронного університету повинна бути пристуньої в сучасних закладах та обов'язково включати в себе питання зі створення/використання системи управління навчанням та іiі підтримки.

Електронний університет є інтеграційним електронним середовищем в яке входить ціла низка різноманітних модулів, серед яких системи управління навчанням (з англ. LMS - learning management system) і системи управління навчальним контентом (з англ. LCMS learning content management system). У нас їх часто плутають 3 терміном «система дистанційного навчання» (СДО, з англ. E-learning management system), при цьому маючи на увазі програмний комплекс, який дозволяє планувати, забезпечувати, управляти i враховувати взаємодію учня, навчального контенту і викладача [1]

Таким чином, система управління навчанням - це програмно-апаратна платформа, яка дає можливість планувати і проводити навчальний процес, управляти і контролювати процес отримання знань, а також вести облік і аналіз результатів навчання.

Найбільш відомими і популярними серед програмних платформ для дистанційного навчання є STEPIC, Moodle, iSpring. уроків.

Stepik - це освітня платформа i конструктор безкоштовних відкритих онлайн-курсів i

Stepik дозволяє будь-якому зареєстрованому користувачу створювати інтерактивні навчальні уроки і онлайн-курси, використовуючи відео, тексти та різноманітні завдання 3 
автоматичною перевіркою і моментальної зворотним зв'язком. В процесі навчання студенти мають можливість вести обговорення між собою і ставити питання викладачеві в коментарях.

Проект співпрацює як з освітніми установами, так і з індивідуальними викладачами та авторами.

Перші освітні матеріали були випущені 3 вересня 2013 року. В даний час на платформі доступні курси з програмування, математики, біології, економіці, психології, журналістиці та культурі.

Ще одна система, що працює в сфері віртуальної освіти, називається Moodle. Вона також відома як система управління навчанням або віртуальне навчальне середовище, що має відкритий код і вільно розповсюджується, за допомогою якого можна створювати сайти для навчання онлайн. Система насамперед орієнтована, на те, щоб організувати взаємодію між викладачем і учнями, але також вона підходить і для організації традиційних дистанційних курсів та підтримки стаціонарного навчання. Moodle перекладена багатьма мовами, в тому числі. Вона активно використовується майже в 50 тисячах організацій 3 більш ніж 200 країн світу. У нашій країні зареєстровано понад 1000 інсталяцій Moodle. Завдяки добре розвиненою модульній архітектурі, можливості Moodle можуть легко бути розширені сторонніми розробниками за рахунок інтеграції підсистеми для організації вебінарів чи вебконференцій [2]. Але технологічна складність системи вимагає наявності команди розробників і супроводжуючого персоналу для підтримки та адаптації системи.

Третя платформа - iSpring - розробник програмних продуктів для дистанційного навчання і оцінки персоналу. Вона в собі містить програми для розробки навчальних матеріалів (онлайн-презентацій, курсів, тестів, навчальних ігор) на основі PowerPoint. Також iSpring $є$ популярною системою Дистанційного Навчання (СДО) для їх розміщення i отримання докладної статистики. Сфери застосування даної платформи дуже різноманітні, вона може застосовуватися для корпоративного навчання та оцінки персоналу, для презентації на виставках і конференціях, для проведення бізнес-тренінгів, а також для безпосереднього навчання в школі або у ВНЗ.

Досвід Вінницького національного технічного університету дозволяє зробити висновок про те, що достатньо зручно використовувати власні розробки. Так, системи JetIQ та LoD разом з сервісами Google for Education дозволяють сформувати базову технологічну основу середовища електронний університет. Така інтегрована система містить і функції, що перераховані в аналогах, і спеціальні функції, адаптовані до особливостей організації навчання у ВНТУ. Головні проблеми - відсутність високооплачуваних фахівців для розробки та тестування модулів, виконання робіт з безпеки та серверної підтримки, навчання викладачів.

Висновки. Розвиток систем управління навчання в подальшому передбачає забезпечення їх ще більшою інтерактивністю. Насправді, всі ми знаємо, що навчання без реального спілкування 3 викладачем не може бути повноцінним. Тому необхідно використовувати поєднання різних типів електронних комунікацій, що дозволяє компенсувати недолік особистого контакту за рахунок віртуального спілкування. Крім того, інтеграція різноманітних модулів інтегрованої системи «Електронний університет» повинна здійснюватися 3 врахуванням питань безпеки та серверного навантаження. Супроводження системи управління навчанням повинні здійснювати спеціальні підрозділи з відповідною оплатою висококваліфікованих фахівців.

\section{Список використаних джерел:}

1. Top Learning Management System Trends for 2014 [Електронний ресурc] // http://elearningindustry.com/toplearning-management-system-trends-for-2014.

2. Духнич Ю. Система дистанційного навчання [Електронний peсурс] / Ю. Духнич // http://www.smart edu.com/sistema distantsionnogo obucheniya.html. 
Дьяченко С.В., студентка 4 курсу

Навчально-науковий інститут харчових технологій, Україна

Науковий керівник: Пасічний В.М., професор

Навчально-науковий інститут харчових технологій, Україна

\section{УДОСКОНАЛЕННЯ ТЕХНОЛОГІї “SOUS VIDE" ДЛЯ ПРОДУКТІВ 3 М'ЯСА ПТИЦІ}

Вступ. У сучасному світі розширення асортименту м'ясопродуктів з використанням м'яса птиці знаходиться в тренді інновацій [1].

При цьому поряд з удосконаленням традиційних технологій виробництва м'ясних і м'ясомістких продуктів на основі м'яса птиці інтенсивно розвиваються технології 3 використанням цільової ферментації [2, 3], а також направлені на впровадженя енергозберігаючих технологій. Одним 3 напрямків підвищення привабливості даної продукції для споживача є технологія “SousVide", яка дозволяє забезпечити високий рівень організації технологічного процесу, знизити втрати у виробництві та розширити асортимент продукції [4].

Матеріали та методи. Суть даної технології полягає в упаковуванні продуктів у непроникний (полімерні) плівки або пакети з подальшим видаленням повітря з пакету, куди ми помістили продукт [5].

Переваги даної технології $\epsilon$ зменшення втрат вологи продукту у процесі термообробки, а також зменшення температури проведення термообробки шляхом створення розрідженого середовища під плівкою.

Розрідження, близьке до вакууму, що створюється внаслідок видалення повітря 3 простору під упаковкою, дозволяє знизити температуру кипіння вологи у продукті, в той же час унеможливлюючи втрати вологи у навколишнє середовище і при необхідності використовувати спеціалізовані ферментні препарати та маринади.

Результати. Згідно плану дослідження було розроблено рецептури зразків, що відрізняється видом використовуваної м'ясної сировини і також включали в себе маринад. Використовували куряче філе та качину грудку, маринад.

Вміст вологи зразків, рецептура яких включала в себе м'ясо птиці, має більші значення, досягаючи максимуму для зразка 3 після 7 діб зберігання - 74,4 \%, а мінімуму для зразка 2 після 14 діб зберігання, досягаючи 62,4\%.

Значення активності води в усіх дослідних зразках було на рівні $0.620 \ldots 0.624$ одиниць, що вказує на достатньо низку здатність до розвитку процесів мікробіологічного псування сировини. Максимальне значення В3З зафіксовано у зразків качиного філе і курячої четвертини відповідно через 7 і 14 діб зберігання. Варто відзначити, що значення В33 не зазнали відчутного зниження для усіх зразків протягом терміну зберігання, різниця між показником після 7 та 14 діб була не більшою за 3\%.

Вологозв'язуюча здатність усіх зразків знаходиться у залежності з консистенцією продукту. Таким чином вона має найнижчі значення серед дослідних зразків для зразка 1 , оскільки він включає в свою рецептуру філе курчат бройлерів, яке є більш чутливим до термічної обробки і осмотичних процесів, ніж сировина, що використовувалась у інших зразках.

Значення активності води в усіх дослідних зразках було на рівні $0.620 \ldots 0.624$ одиниць, що вказує на достатньо низку здатність до розвитку процесів мікробіологічного псування сировини.

При видаленні повітря 3 пакету, м'ясо злегка розширюється, i його пори відкривається, що дозволяє використовувати маринадам ефективніше проникати, чим при 
традиційних способах приготування, покращуючи однорідність смаку по всьому об'єму продукту.

За відсутності повітря зменшується окислення продукту, і він повністю занурюється у використовуваний маринад, розсіл або спеції.

Розширення асортименту продуктів з м'яса птиці в технології “SousVide” дозволяє підвищувати конкурентоспроможність вітчизняних промислових і готельно-ресторанних підприємств.

Висновки. Дослідним чином встановлено, що при використанні технології "SousVide" продукти 3 м'яса птиці набувають кращих органолептичних та структурномеханічних властивостей, ніж приготовлені традиційним способом.

Подальші дослідження будуть спрямовані на виявлення можливості підвищення функціонально-технологічних показників м'ясопродуктів вироблених за технологією «SousVide», з використанням цільової ферментації і білоквмісних композитів.

\section{Список використаних джерел:}

1. Bozhko, N., Tischenko, V., Pasichnyi, V., Yuschko, M., Zhukova, Y., \& Popova, E. (2018). Study of functional and technological indices of meat-containing loaf with Muscovy duck meat and white carp. Scientific Messenger of LNU of Veterinary Medicine and Biotechnologies. Series: Food Technologies, 20(85), 19-23. https://doi.org/10.15421/nvlvet8504

2. Shvedyuk, D., Pasichnyi, V., Moroz, O., \& Heredchuk, А. (2018). Вплив протеази мікробіологічного походження на процес автолізу у м'ясі курчат-бройлерів. НВ ЛНУ ветеринарної медицини та біотехнологій. Серія: Харчові технологіï, 20(90), 32-35. https://doi.org/10.32718/nvlvet9007

3. Ukrainets, A., Pasichnyi, V., Shvedyuk, D., \& Matsuk, Y. (2017). Дослідження здатності до протеолізу м'ясних січених напівфабрикатів функціонального призначення. НВ ЛНУ ветеринарної медицини та біотехнологій. Серія: Харчові технологіï, 19(75), 129-133. https://doi.org/10.15421/nvlvet7526

4. Пасічний В.М. Вплив застосування технології sous vide на різні види м'яса птиці. / Пасічний В.М., Гармаш Д.В., Рамік О.С., Кохан Б.А. // Харчова промисловість. К, НУХТ, 2018. С. 70-76. https://doi.org/10.24263/2225-2916-2018-24-11

5. Garmash, D., \& Pasichnyi, V. (2019). Вплив застосування технології sous vide на функціональнотехнологічні характеристики продуктів на основі різних видів м'ясної сировини. Вісник Національного технічного університету «ХПI». Серія: Нові рімення у сучасних технологіях, (1), 67-74. https://doi.org/10.20998/2413-4295.2019.01.08

Карбаев Казбек Кайратович, соискатель степени магистра машиностроительного факультета

Карагандинский государственный технический университет, Казахстан

Научный руководитель: Серова Роза Фаиковна, к.т.н., доцент кафедры

«Строительные материалы и технологии»

Карагандинский осударственньй технический университет, Казахстан

\section{ФОРМИРОВАНИЕ БЕТОННОЙ СМЕСИ С ИСПОЛЬЗОВАНИЕМ СТЕКЛОБОЯ}

Цель работы - разработать модель формообразования смесей с неорганическим связующим на примере бетонной смеси, с применением мелкодисперсного стекла для замещения части цемента.

Дисперсными системами называются гетерогенные системы, в которых одно вещество в измельченном виде размещено равномерно по всему объему второго вещества. Размельченное вещество называется дисперсной фазой. Второе вещество называют дисперсной средой. В статье в качестве дисперсной системы была выбрана бетонная смесь, 
где дисперсной средой является цементное тесто, а дисперсная фаза представлена в виде крупных и мелких заполнителей(щебень, песок).

Одной из самых актуальных проблем в производстве бетона остается удешевления его компонентов.

В свою очередь, стеклобой является ценным вторичным сырьевым материалом, применение которого имеет большие преимущества в экономии сырьевых ресурсов и охране окружающей среды.

Оконное стекло, использованное в экспериментах имеет 7\% оксида кальция. По некоторым литературным данным, мате риалы, содержащие менее 10 \% СaО, вяжущими свойствами не обладают. В то же время отмечается значительное увеличение пуццолановой реакции в тонкомолотых шлаках. Значит, значительное дробление стекла решит проблему. Для первой попытки в эксперименте была принята тонкость помола, соответствующая цементу, согласно ГОСТ 10178-85.

Помол стекла был произведен в шаровой мельнице. Сито вый анализ тонкости помола стекла выполнен с использованием виброгрохота analysett 3 PRO фирмы FRITISCH (рису нок 1), взвешивание - на электронных весах.

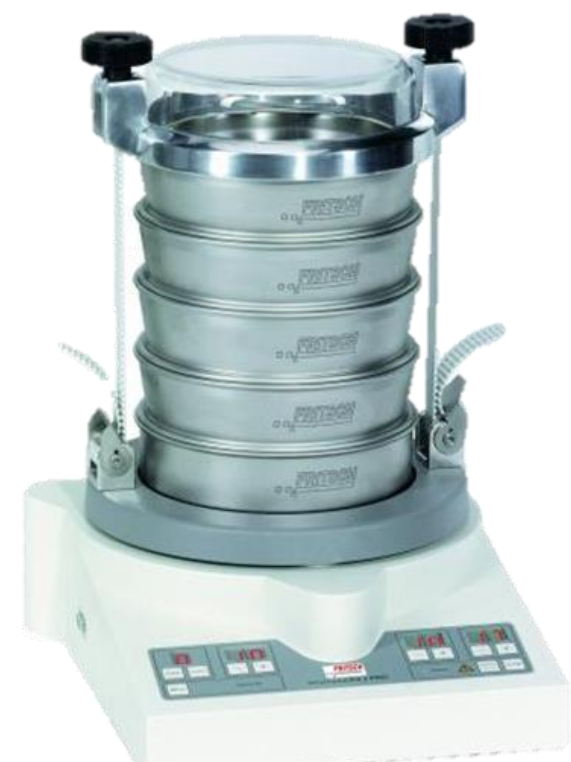

Рис. 1. Виброгрохот analysett 3 PRO фирмы FRITISCH

При замене 10 \% массы цемента мелкодисперсным стек лом прочность образцов при сжатии в 8 сер иях из 10 бы ла выше прочности чисто цементных образцов. Превышение составляло о т 10 до 30 \%. В 2 сер иях прочность оказалась ниже. Однако снижение составляло не бол ее 6,0 \%. Полученные результаты были закреплены в инновационном патенте Республики Казахстан № 21793 С04B 28/02 [2].

При замене 20 \% массы цемента мелкодисперсным стеклом прочность образцов при сжатии и изгибе лишь в 3 случаях из 10 превышала прочность исто цементных образцов. Таким образом, замена 20 \% цемента тонкомолотым стек лом снижает прочность раствора и потому является избыточной. Этот результат подтвердили данные исследований $[3,4]$, определивших максимальную величину добавки стекла в 15\% от массы цемента.

Микрошлифы образца из смеси 1 : 0,6 (стекло - вода) показывают, что основная масса шлифа сложена сцементированными тонкими пылеватыми зернами ( менее 0,001 мм) аморфного стекла, реже отмечаются единичные угловатые отломки размерами 0,01-0,025 мм, повсеместны гнезда зародышевых кристаллов удлиненного габитуса (рисунок 2). Приведенные данные показывают наличие у мелкодисперсного стекла 
вяжущих свойств. При испытании образца на сжатие разрушающее напряжение составило 2,7 МПа.

Таким образом, можно утверждать, что замена $10 \%$ массы цемента мелкодисперсным стеклом не только не снижает прочности цементно-песчаного раствора, но даже увеличивает ее на 10-15\%.

Полученные данные о возможности применения мелкодисперсного стекла взамен цемента требуют подтверждения при испытании бетонных образцов. С этой целью были выполнены дополнительные эксперименты.

На основании рекомендаций были подобраны составы: А - тяжелого бетона без доба вок стекла; Б - тяжелого бетона с заменой 10 \% цемента мелкодисперсным стеклом; В - тяжелого бетона с заменой $15 \%$ цемента тонкомолотым стеклом. Портландцемент M400 Карагандинского завода с добавками: тонкомолотого шлака до 20 \%, двуводного гипса до $6 \%$ и оксида серы до 2,5\%. Фактическая активность отдельных серий составляла 320 - 380 кгс/см2. Из каждого состава формовалось по три куба при одинаковом вибрировании на лабораторном столе с частотой 3000 колебаний в минуту. Серии образцов выдерживались в стандартных условиях в течение 28, 56 сут.

Незначительное снижение прочности в образцах с мелкодисперсным стеклом наблюдается лишь в двух случаях. Таким образом, эксперименты подтвердили возможность замены до 15 \% цемента мелкодисперсным стеклом. Представленные результаты получены при использовании мелкодисперсного стекла возрастом до 1,5 лет при хороших условиях хранения [].

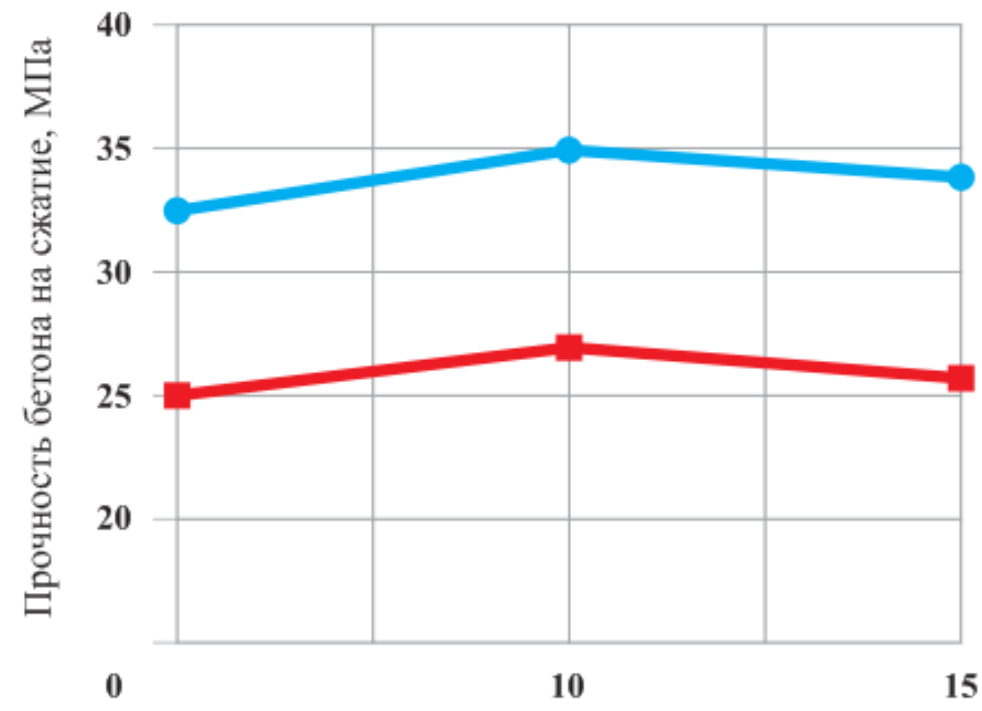

Содержание мелкодисперсного стекла, мас. \% цемента

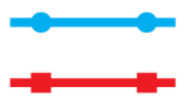

- Обра зцы в возра сте 56 суток

- Обра зцы в возра сте 28 суток

\section{Рис. 2. График зависимости прочности бетона на сжатие от процентного содержания мелкодиспе рсного стекла в составе цемента}

Испытания показали превышение до 25 \% прочности образцов Б и В над прочностью образцов серии $\mathrm{A}$, не соде ржавшей мелкодисперсного стекла.

Из проведенных исследований можно сделать вывод что применение мелкодисперсного стекла для замены части цемента является приемлемым способом для уменьшения использования цемента, так и для улучшения прочностных свойств бетонной смеси. 


\section{Список использованных источников:}

1. Качанова Ю.Н, Ивлева О.И. Разработка методов физико-механического управления свойствами дисперсных смесей // Материалы Международной студенческой научной конференции «Конкурентоспособные технологии как стержень инновационной экономики Республики Казахстан». Караганда, 2006. - С. 174-175.

2. Буевич Ю.А. Гидродинамическая модель дисперсных систем. ПММ, 1969. - Т. 33, вып. 3. - С. $482-494$.

3. Урьев Н.Б. Высококонцентрированные дисперсные системы. - М.: Химия, 1980 . -320 с.

4. Дерягин Б.В., Чураев Н.В., Муллер В.М. Поверхностные силы. - М: Наука, 1987. - 398 с.

5. Дерягин Б.В., Кротова Н.А., Смилга В.П. Адгезия твердых тел. - М.: Наука, 1973. - 280 с.

Кішка Богдан Васильович, студент

Одеський начіональний політехнічний університет, Украӥна

Науковий керівник: Бобріков Сергей Одексанрович, доц., канд. техн. наук

Одеський національний політехнічний університет, Україна

\section{ЦИФРОВА СИСТЕМА УПРАВЛІННЯ КУТОВИМІРЮЮЧИМ ПРИСТРОСМ НАВІГАЦИЙНОГО КОМПЛЕКСУ}

Антена радіотелескопа - пристрій для збору радіовипромінювання космічних об'єктів. Антена радіотелескопа визначає його чутливість (мінімально виявлений сигнал) i кутовий дозвіл (здатність розділити випромінювання близьких друг до друга радіоджерел).

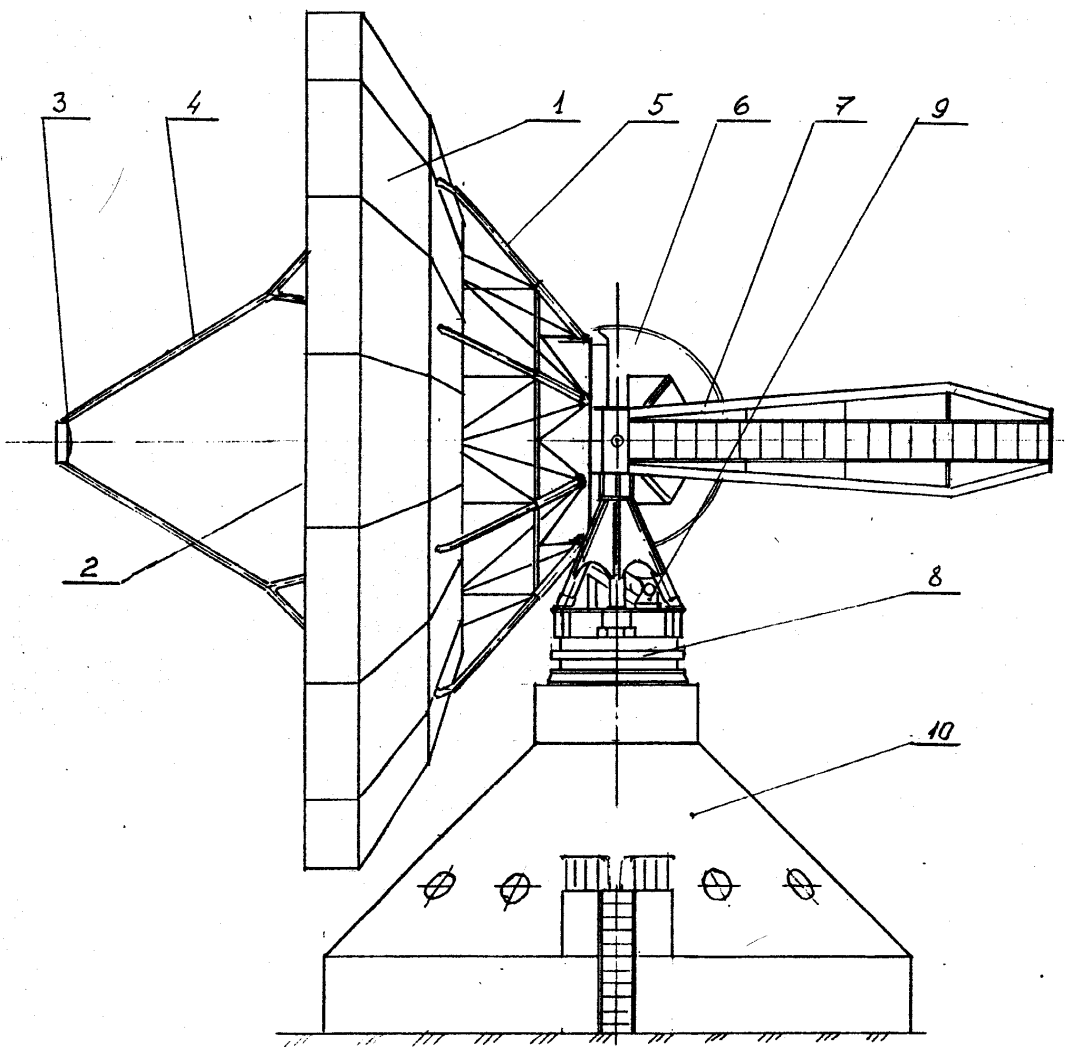

Рис. 1. Конструкція радіотелескопа РТ-16

1 - Термоізольований каркас дзеркал; 2 - Поверхня, що відбиває; 3 - Кассегреновский контррефлектор; 4 - Опорна піраміда контр рефлектора; 5 - Ферменно-стрижнева проміжна конструкиія; 6 - Зубчасті сектори кутомістного обертання; 7 - Противаги; 8 - Опорне коло азимутального обертання; 9 - Редуктори; 10 - Пілон фундаменту. 
На різних етапах розвитку антенної техніки й апаратури радіотелескопа МГТУ були розроблені конструкції й технології виготовлення антен міліметрового діапазону діаметром від 0,1 до 16 метрів (РТ-16) і приймачі різних типів, які набули застосування в дослідницьких стендах. На рисунку 1 представлена конструкція одного 3 таких повноповоротних радіотелескопів

Рух антени по азимуті й куту місця забезпечується двома групами приводів приводом великої швидкості, призначеним для швидкого перекидання антени з одного радіоджерела на інший, а також для спостережень радіо джерел, що швидко рухаються і приводом малої швидкості, що дозволяє здійснювати програмний супровід радіоджерел 3 високою точністю. Приводи розташовані в азимутальній кабіні.

Основні механічні характеристики антени

Діапазон швидкостей:

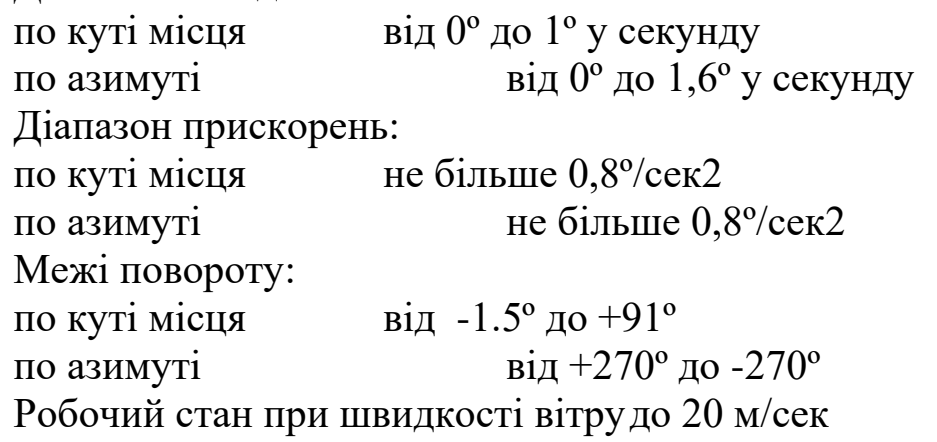

Цифрова система контролю й керування радіотелескопом обсерваторії "Світле", розроблена на базі комп'ютерних плат Octagon i Fastwell iз програмним забезпеченням в операційному середовищі Linux, забезпечує спостереження повільних (природних) i швидких (штучних) радіоджерел з точністю не гірше 2 секунд дуги. Цифрова система реалізує алгоритм керування ("ПИД-алгоритм"), завдяки якому радіотелескоп 3 масою більше 700 тонн рухається енергійно й без помітних автоколивань системи.

Для виконання високих вимог до всіх перерахованих вище повноповоротних радіотелескопів необхідна позиційна система, що стежить, до складу якої входять електронні пристрої, що забезпечують прецизійну точність наведення, i електромеханічні пристрої, що здійснюють обертання антени по азимуті й куту місця 3 досить великими кутовими швидкостями.

При проектуванні системи, що стежить, можна виділити наступні іï основні частини: прилад формування сигналу помилки, що містить у собі редуктор і вимірювальні елементи, підсилювальні й перетворюючі пристрої; виконавчі елементи 3 підсилювачами потужності; механічні передачі й допоміжні елементи або пристрої.

Вимірювальні елементи можна розділити на датчики головного зворотного зв'язку й датчики місцевих зворотних зв'язків, що формують коригувальні сигнали. У системах, що стежать, деяких типів датчики головного зворотного зв'язку можуть бути відсутні.

Підсилювальні пристрої залежно від виду вимірювальних і виконавчих елементів можуть бути електронними, магнітними, гідравлічними або пневматичними. До підсилювальних пристроїв відносять і блоки підсумовування, на яких здійснюється додавання сигналу помилки й сигналів місцевих зворотних зв'язків. Як блоки підсумовування зручно використовувати операційні підсилювачі.

\section{Список використаних джерел:}

1. Лакота Н.А. Основы проектирования следящих систем. - М., 1978p.

2. Шамшура В.I. Техника радиолокации. Ч.2. Схемы и элементы радиолокационных станций. - М. Воениздат $1949-352 c$. 
3. Катков С.А., Кромин Г.С. Основы радиолокационной техники. - М. Воениздат 1959

4. Макс Ж. Методы и техника обработки сигналов при физических измерениях. 2Тома. Под редакцией Волкова Н.Г. - М. Мир 1983

5. Жуховецкий Б.Я. Сигналы телемеханики и их преобразование (изд. 2-е перераб.). - М.Энергия 1968

6. Маркюс Ж. Дискретизация и квантования. - М.Энергия 1969

Подлипенский В.С., Петренко В.Н. Электромагнитные и электромашинные устройства автоматики. - К. Вища шк. Головне видавництво 1987 - 592с.

Под редакцией Н.М. Чумакова Расчет исполнительных корректирующих и преобразовательных элементов автоматических систем. - К. Техника, 1971. -308c. 


\section{СЕКЦІЯ 3. ФІЗИКО-МАТЕМАТИЧНІ НАУКИ}

DOI 10.36074/29.05.2020.v2.02

Костенко Олексій Віталійович, здобувач вищої освіти факультету прикладної математики Дніпровський національний університет імені Олеся Гончара, Україна

Ракіта Настасія Євгенівна, здобувач вищої освіти факультету прикладної математики Дніпровський національний університет імені Олеся Гончара, Украӥна

\section{ЗАСТОСУВАННЯ НЕЙРОННИХ МЕРЕЖ ДЛЯ АПРОКСИМАЦІЇ ФУНКЦЙ}

При проведенні теоретичних досліджень і практичних розрахунків в багатьох областях науки і техніки, у тому числі, для математичного та програмного забезпечення систем обробки зображення у реальному часі виникає необхідність в апроксимації (наближенні) функцій. Апроксимація (Approximation) взагалі - це наближений опис однією функцією (апроксимувальною) заданого вигляду іншої функції (апроксимованої), яка задається у будь-якому вигляді (при апроксимації даних вона задається у вигляді масивів даних). Серед інших методів апроксимації функцій набуло розвитку застосування нейронних мереж.

Одною із математичних проблем, сформульованих Д. Гільбертом у 1900, під 13 номером стояло питання про можливість представлення функції $\mathrm{n}$ змінних у вигляді суперпозиції функцій меншого числа змінних. В 1956 р. А. М. Колмогоров [1] і В. Арнольд [2] показали, що це можливо, крім того неперервна функція $\mathrm{n}$ змінних може бути представлена у вигляді суперпозиції одномісних функцій та операції суми. Необхідність в представлення функції $\mathrm{n}$ змінних у вигляді суперпозиції функцій меншого числа змінних знову з'явилась в зв'язку з розвитком теорії та практики застосування нейронних мереж. Появу теорії нейронних мереж пов’язують зі статтею У. Мак-Калока та У. Пітца [3] , в якій була описана математична модель нейрону та нейронної мережі та запропонованою Розенблаттом моделлю нейрона, яку він назвав перцептроном. В 1989 році Г. Цибенко [4], К. Фуханаші [5] та К. Хорнік [6] незалежно довели наступний факт. Нехай $\psi$ - фіксована сигмоїдна функція, а $f$ - неперервна на компакті $K \subset R^{n}$. Тоді $f$ можна апроксимувати (рівномірно наблизити) за допомогою 4 шарів (два приховані шари) причому функції вхідного та вихідного шарів лінійні, а для прихованих шарів рівні $\psi$.

Отже, відомо, що для будь-якої наперед заданої точності існує наближення неперервних функцій за допомогою нейронних мереж з сигмоїдними функціями активації. Існують методи навчання мереж, наприклад метод зворотного поширення помилки. При цьому питання конструктивної побудови та підбір параметрів мережі, ще вивчаються.

Було вирішено створити програмне забезпечення, яке дозволить швидко будувати модель нейронної мережі, що апроксимує різні функції на відрізку. Функція подається аналітичним виразом або набором даних.

Для реалізації поставлених цілей було обрано бібліотеку РуTorch [7], функціонал якої дозволяє легко створювати та навчати моделі ШНМ, і інтегроване середовище розробки програмного забезпечення Jupyter notebooks [8]. Розробка та запуск виконується у веб лабораторії Google Colab [9].

Були розглянуті та реалізовані деякі моделі нейронних мереж з різною кількістю нейронів, різними функціями активації. За допомогою бібліотеки matplotlib [10] процес 
навчання було візуалізувано. Реалізовано можливість нормалізації або стандартизації вхідних даних, можливість додавання похибки вимірювання (зашумлення) для вхідних даних. Для боротьби з зашумленістю даних та перенавчанням додано можливість регуляризації параметрів моделі ШНМ.

Отже, за допомогою розробленої програми користувач може розглядати вплив складності моделі, нормалізації даних, кількості вхідних даних, використання підходів для боротьби з перенавчанням, забезпечення стійкості моделі на швидкість навчання, та якість прогнозу за допомогою навченої нейронної мережі.

\section{Список використаних джерел:}

1. Колмогоров А. Н. О представлении непрерывных функций нескольких переменных суперпозициями непрерывных функций меньшего числа переменных // ДАН СССР.—1956.-Т. 108.—С. 2.

2. Арнольд В. И., О представлении функций нескольких переменных в виде суперпозиции функций меньшего числа переменных,Мат. Просвещение, Сер. 2, вып. 3, (1958)

3. Мак-Каллок У., Питтс У. Логическое исчисление идей, относящихся к нервной активности // Автоматы.М.: Изд. иностр. лит., 1956.-С. 362-384.

4. Cybenko G. Approximations by superpositions of sigmoidal functions // Math. Control Signals Systems.1989.-Vol. 2.-P. 303-314.

5. Funahashi K. On the approximate realization of continuous mappings by neural networks// Neural Networks.1989.-Vol. 2, no. 3.-P. 183-192.

6. Hornick K., Stinchcombe M., White H. Multilayer feedforward networks are universal approximators // Neural Networks.-1989.-Vol. 2, no. 5.-P. 359-366.

7. https://pytorch.org/docs/stable/index.html

8. https://jupyter.org/documentation

9. https://research.google.com/colaboratory/faq.html

10. https://matplotlib.org/contents.html

Дмітрова Кароліна Миколаївна, здобувач вищої освіти математичного факультету Запорізький національний університет, Украӥна

\section{НЕІТЕРАЦЙНІ МЕТОДИ ЗВЕДЕННЯ ЗВИЧАЙНИХ ДИФЕРЕНЦІАЛЬНИХ РІВНЯНЬ 3 КРАЙОВИМИ УМОВАМИ ДО ЗАДАЧ КОШІ}

Двоточковими крайовими задачами моделюється велика кількість фізичних, механічних, хімічних, біологічних процесів. Багато крайових задач теорії пластин, оболонок розв'язується зведенням їх до задачі Коші. Одним із найпоширеніших застосувань має метод початкового параметра в задачах гідромеханіки [2], в задачах стійкості підкріплених (шпангоутами, стрингерами) пластин і оболонок, що застосовуються у авіа-, судо-, ракетобудуванні та інших галузях промисловості [3].

Розглянемо звичайні диференціальні рівняння другого порядку виду $F\left[x, y(x), y^{\prime}(x), y^{\prime \prime}(x)\right]=0, \quad x \in[a, b] \quad 3 \quad$ крайовими $\quad$ умовами $\quad \alpha_{1} y^{\prime}(a)+\alpha_{2} y(a)=A$, $\beta_{1} y^{\prime}(b)+\beta_{2} y(b)=B$.

До неітераційних методів зведення ЗДР з крайовими умовами до задач Коші відносяться: метод суперпозиції, метод прогонки, метод спряженого оператора, метод перетворення, метод диференціювання за параметром, метод інваріантного занурення [1, c.11].

На нашу думку, найбільш доцільним $є$ використання методу прогонки (метод початкового параметра). Розв'яжемо цим методом лінійну крайову задачу: 


$$
\begin{gathered}
y^{\prime \prime}=y \sqrt{x^{2}+\frac{5}{4}}-\frac{1}{2} e^{x}, \\
y^{\prime}(o)=y(0)+\frac{3}{2}, \quad y^{\prime}(1)=-\frac{1}{2} y(1)-1 .
\end{gathered}
$$

Приведемо дану задачу до системи двох диференціальних рівнянь першого порядку виду з початковими умовами:

$$
\left\{\begin{array}{c}
f_{1}^{\prime}+\left(f_{1}\right)^{2}=\frac{1}{2} \sqrt{4 x^{2}+5}, \\
f_{2}^{\prime}+f_{1} f_{2}=-\frac{1}{2} e^{x},
\end{array} f_{1}(0)=1, f_{2}(0)=\frac{3}{2} .\right.
$$

Розв’язавши дану задачу Коші, отримаємо функцію зображену на рис. 1:

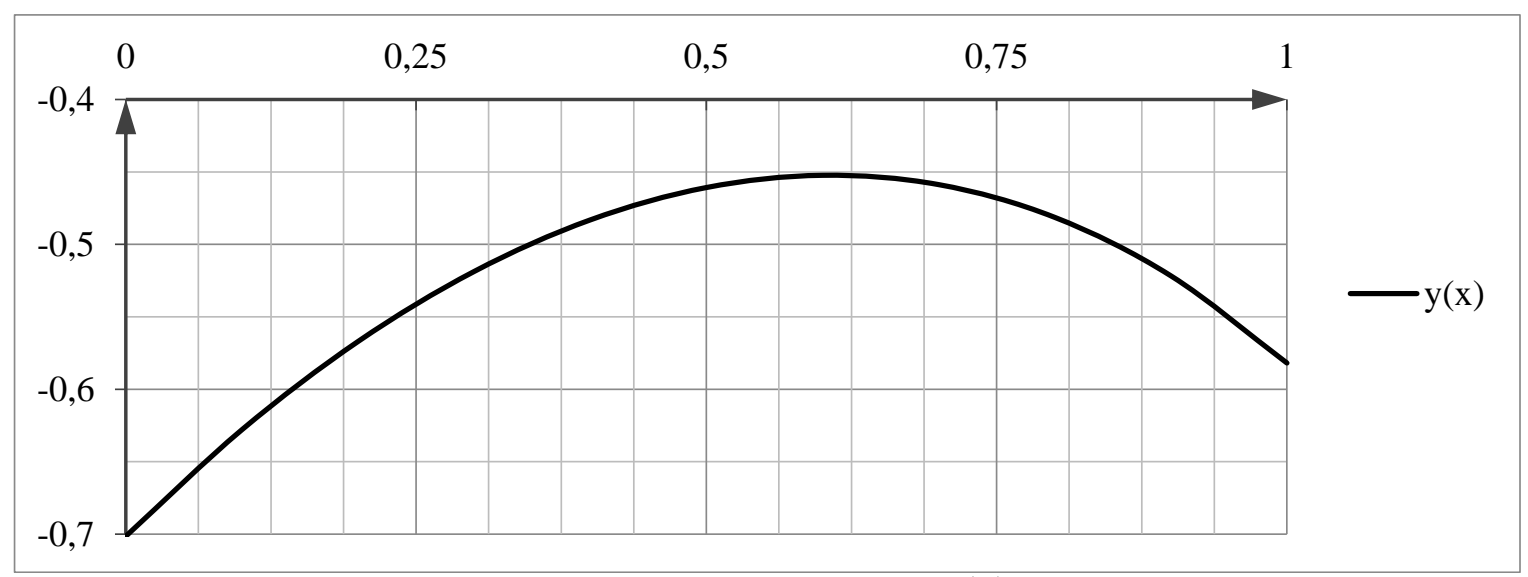

Рис. 1 Графік функції $y(x)$.

Отже, неітераційні методи зведення ЗДР з крайовими умовами до задач Коші є достатньо простими і точними. Головним їхнім недоліком $\epsilon$ те, що вони дають змогу знайти розв’язок лише лінійного ЗДР. Для розв'язання нелінійних ЗДР зазвичай необхідно використовувати ітераційні методи.

\section{Список використаних джерел:}

1. На, Ц. (1982). Вычислительные методы решения прикладных граничных задач: (В. Е. Кондрашова, А. С. Сухих, пер с англ.). Москва: Мир.

2. Орыняк, И. В., Батура, А. С., Дубик, Я. Р. (2012). Применение метода начальных параметров к анализу связанных гидромеханических колебаний трубопроводных систем. Проблемы прочности, (1), 14-29.

3. Преображенский, И. Н. \& Грищак, В. 3. (1986) Устойчивость и колебания конических оболочек. Москва: Машиностроение. 
Дженкова Марія Миколаївна, здобувач вищої освіти факультету прикладної математики Дніпровський Національний Університет ім. О. Гончара, Украӥна

Науковий керівник: Черницька Ольга Валентинівна, кандидат фіз.-мат. наук, доцент, доцент кафедри обчислювальної математики та математичної кібернетики Дніпровський Національний Університет ім. О. Гончара, Украйна

\section{СИСТЕМИ МАСОВОГО ОБСЛУГОВУВАННЯ В ХОСТИНГОВИХ КОМПАНІЯХ}

В умовах сучасного світу ведення бізнесу в мережі $є$ основоположним чинником успіху проекту. Цей факт підтверджує кількість IT-компаній в будь-якій точці світу. Тим не менш, далеко не всі сфери діяльності напряму пов'язанні з IT: наприклад, продаж одягу, ресторани. Дивлячись на глобальну ситуацію зрозуміло, що бізнес, який не в змозі використовувати привілеї інтернету, не зможе довго існувати. В цьому випадку на допомогу тим, хто не є професіоналом у сфері IT, приходять хостингові компанії, які надають послуги хостингу клієнтам, тобто дозволяють розміщувати на своїх майданчиках (наприклад, у датацентрах) клієнтське обладнання, дані, веб-сайти.

Наразі, розміщення клієнтських ресурсів, наприклад, веб-сайтів, на обладнані хостингової компанії є дуже поширеною практикою. Оскільки для коректної роботи вебсайту необхідно забезпечувати безперервну доступність ресурсу для користувачів, власники веб-сайтів користуються послугами хостингових компаній, які, в певних випадках, пропонують підтримку стабільної роботи сервера, на якому розміщено ресурс. Клієнту не потрібно мати власне приміщення, обладнання або отримувати для свого сайту «білу» ір-адресу самостійно. Таким чином, хостингові компанії значно полегшують життя звичайним власникам веб-сайтів, які не є спеціалістами в сфері IT.

Оскільки хостингові компанії дуже часто співпрацюють 3 клієнтами напряму, вони $\epsilon$ дуже гарним прикладом системи масового обслуговування. Сучасні компанії можуть налічувати тисячі одиниць обладнання та десятки тисяч клієнтів. Для стабільної роботи такої системи необхідно мати кілька відділів, які співпрацюють між собою, та платформу для обслуговування клієнтів. Моделювання та оптимізація подібних систем $є$ важливою задачею для бізнесу.

В роботі розглядається система масового обслуговування в хостинговій компанії, яка налічую приблизно 10000 клієнтів та 50 співробітників в різних відділах. Ці дані відображають реальну ситуацію в одній з хостингових компаній. Моделювання системи дозволить зрозуміти, чи працює система в оптимальному режимі, та чи може їі робота призвести до переповнення черги та деградації продуктивності системи.

Система масового обслуговування в розглядуваній хостинговій компанії працює наступним чином. При виникненні питань з роботи послуг компанії клієнти мають змогу звернутися до служби технічної підтримки. Заявки клієнтів потрапляють в чергу та опрацьовуються поступово. При цьому, деякі заявки можуть бути виконані відразу, а деякі можуть бути передані до іншого відділу (рис. 1). Передача заявок до іншого відділу залежить від типу заявки.

Модель системи масового обслуговування в наведеній хостинговій компанії має наступні характеристики:

- вхідний потік має пуассонівський розподіл [1];

- час обслуговування визначається експоненціальним законом [2];

- оскільки не всі працівники відділу технічної підтримки працюють одночасно, доступно від 5 до 10 працівників відділу технічної підтримки паралельно;

- всі черги системи мають дисципліну «перший прийшов - перший обслуговується»;

- $з$ початкової черги можуть формуватися черги до інших відділів; 
- для опрацювання черг інших відділів доступно від 2 до 10 одночасно працюючих співробітників;

- після опрацювання заявки іншим відділом, заявка повертається працівнику відділу технічної підтримки та потрапляє в його особисту чергу (особиста черга виникає, оскільки наступні заявки продовжують опрацьовуватися, якщо поточна потрапила в чергу іншого відділу);

- всі черги в системі необмежені;

- вхідний потік клієнтів є нескінченним [2].

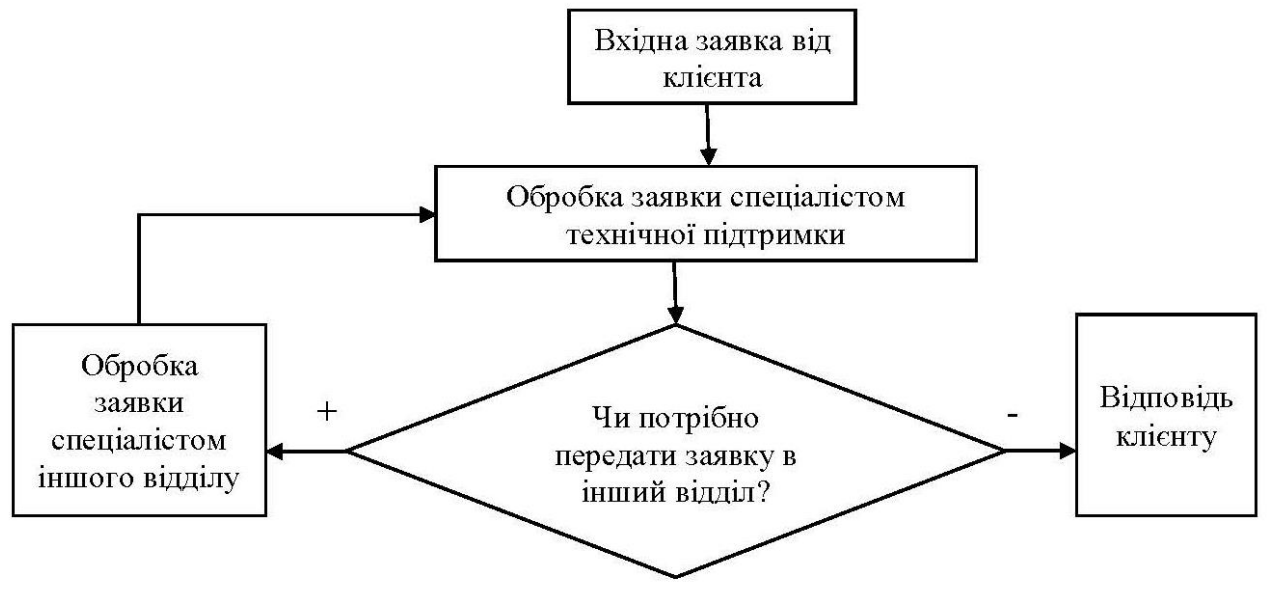

\section{Рис. 1. Спрощена схема роботи системи масового обслуговування в хостинговій компанії [авторська розробка]}

Для побудови системи масового обслуговування в наведеній хостинговій компанії було розроблено програму на мові програмування С\#. В програмній розробці реалізовані потоки, які виконують роль робітників. Також використовуються черги: вхідна, черга кожного робітника служби технічної підтримки, черги різних відділів. Заявки надходять та обробляються з випадковою періодичністю. Кожна заявка має поле, яке відповідає типу заявки, який обирається випадковим чином. Після проходження системи заявка потрапляє в вихідний потік. Для кожної заявки можна відслідковувати час надходження, час передачі до іншого відділу (якщо потрібно) та час виходу з системи, а також бачити, в якій черзі наразі знаходиться заявка. В програмі також можна дивитися статистику системи.

Для більш наглядних результатів швидкість генерації заявок та їх обробки було збільшено в 60 разів. Результат роботи програми наведено на наступному рисунку (рис. 2).

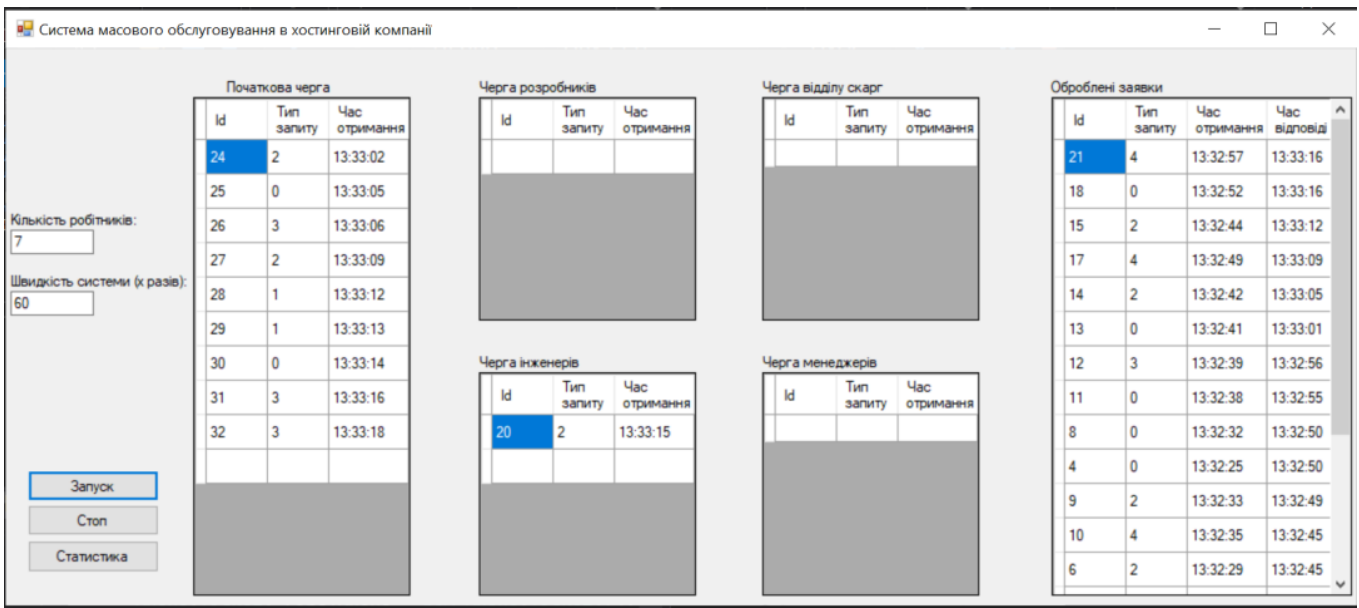

Рис 2. Результат роботи програми з початковими даними [авторська розробка] 
3 результатів зроблено висновок, що система працює стабільно, але початкова черга швидко переповнюється, тобто кількість працівників технічної підтримки не є достатньою. При збільшені кількості робітників до 7, система стала більш збалансованою та перестала бути перевантаженою (рис. 3).

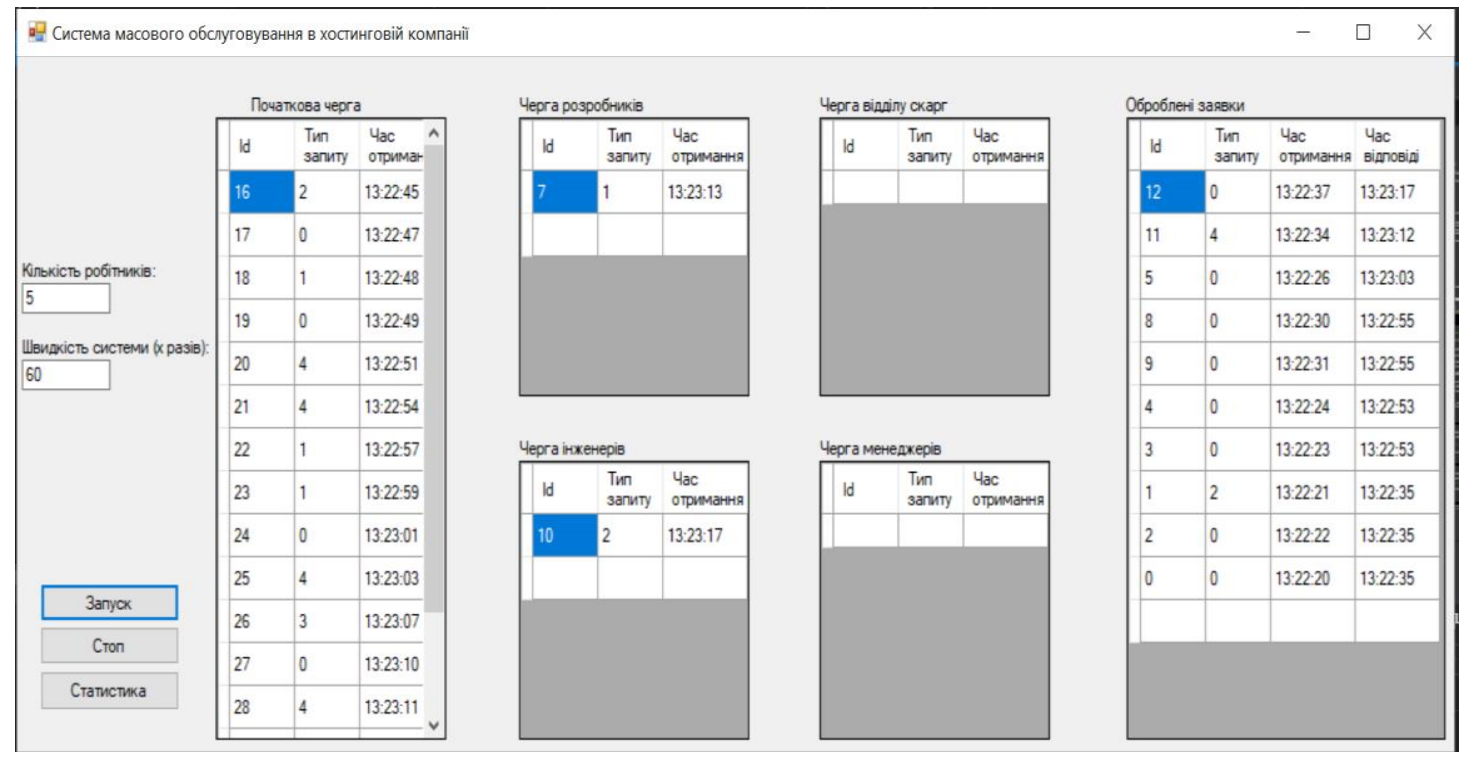

Рис 3. Результат роботи програми після аналізу початкових даних [авторська розробка]

Висновки. Моделювання системи масового обслуговування в хостинговій компанії дозволило зрозуміти темпи росту черги та проаналізувати наскільки продуктивною $є$ система. 3 результатів роботи програмної розробки було зроблено висновок, що система працює недостатньо продуктивно.

\section{Список використаних джерел:}

1. Рукосуев А., Башлыков В., Балдин К.. Основы теории вероятностей и математической статистики. Учебник. Litres, 2016. 489 c.

2. Hamdy A. Taha. Operations Research: An Introduction. 7th edition. Pearson Education, Inc., 2005. 912 p. 
СЕКЦІЯ 4. ХІМІЧНІ НАУКИ

\author{
Краснопір Микола Миколайович \\ Національний технічний університет України \\ «Київський політехнічний інститут імені Ігоря Сікорського», Украӥна
}

Науковий керівник: Пилипенко Тетяна Миколаївна $\bullet$, канд. техн. наук, доцент, доцент кафедри фізичної хімії

Начіональний технічний університет Украӥни

«Київький політехнічний інститут імені Ігоря Сікорського», Украӥна

\title{
ДИКОМПОНЕНТНІ СУМІШІ 3 N-КАРБОНІЛВМІСНИМИ ГРУПУВАННЯМИ
}

У роботі досліджено захисну дію піридинісвих солей $3 \mathrm{~N}$-карбонілвмісними групуваннями [1] у суміші з відповідними піридинійгідрогалогенідами. Встановлено їх значний вплив на корозійну стійкість різних марок сталей в розчинах кислот, а також у корозивних середовищах за наявності в них сірководню. Виявлено, що більшість досліджених сумішей проявляють хороші біоцидні властивості та гальмують мікробну корозію сталі в присутності сульфатредукуючих бактерій (СРБ).

Інгібування корозії сталей в присутності сумішей піридинієвих солей $3 \mathrm{~N}$ карбонілвмісними групуваннями із відповідними піридинійгідрогалогенідами залежать від природи наявних у них замісників. Одержано кореляційні залежності, які підтверджують кількісний зв'язок $[2,3]$ між ефективністю захисної дії досліджених інгібуючих композицій та електронними характеристиками їх замісників.

Ступінь захисту сталей за наявності в корозивному середовищі досліджених дикомпонентних сумішей з $\mathrm{N}$-карбонілвмісними групуваннями дорівнює $96-99 \%$. Висока захисна дія інгібуючих композицій при кислотній корозії сталей обумовлена наявністю в них піридинієвого фрагменту та $\mathrm{N}$-карбонілвмісного групування, а також замісників, які здатні підвищувати їх адсорбційну активність за рахунок електронного чи стеричного ефектів [2]. При цьому наявні в складниках сумішей замісники можуть брати безпосередню участь у процесі адсорбції [4].

Піридинієвий фрагмент забезпечує фізичну адсорбцію досліджених композицій за кімнатної температури, $\mathrm{N}$-карбонілвмісне групування відповідає за їх хемосорбцію [4] та $\epsilon$ визначальним в інгібуванні кислотної корозії сталей за підвищених температур розчину. Біоцидні властивості дикомпонентних сумішей з $\mathrm{N}$-карбонілвмісними групуваннями щодо СРБ також пов’язано з наявністю у складниках сумішей пірідінієвого фрагменту.

Досліджені дикомпонентні суміші піридинієвих солей $3 \mathrm{~N}$-карбонілвмісними групуваннями із відповідними піридинійгідрогалогенідами рекомендовано до використання для захисту від кислотної корозії сталей в широкому діапазоні температур, а також для захисту металоконструкцій в замкнених підземних будовах.

\section{Список використаних джерел:}

1. Yurchenko, R. I., Pogrebova, I. S., Pilipenko, T. N. \& Kras'ko, E. M. (2003). Corrosion-protective properties Nphenacylmethylpyridinium bromides. Russian journal of applied chemistry, 76 (11), 1764-1768.

2. Пилипенко, Т. Н. (2015). Электронный и стерический фактор в защитном действии азот- и кислородсодержащих солей пиридиния. На стыке наук. Физико-химическая серия, 33-35.

3. Pohrebova, I. S. \& Pylypenko, T. M. (2019). Inhibitors for acid corrosion of metals based on quaternary pyridinium salts containing carbonyl groups. Materials Today: Proceedings, 6 (2), 192-201.

4. Pogrebova, I., Iantsevitch, C.\& Krasnopir, T. (2002). The effect of organic substances on inhibition processes of corrosion metals with various kinds of a depolarization. Electrochemistry in molecular and microscopic dimensions, 174. 


\section{СЕКЦІЯ 5.}

\section{БІОЛОГІЧНІ НАУКИ}

Одінцова Марина Олександрівна, студент факультету природничо-географічної освіти та екології Національний педагогічний університет імені Михайла Петровича Драгоманова, Украйна

\section{ВРЕДИТЕЛИ И БОЛЕЗНИ АКТИНИДИИ (КИВИ)}

Достаточное место среди нетрадиционных культур занимает актинидия, которая одновременно может использоваться в пищевых, лекарственных ы декоративных целях.

Растения актинидии зимостойкие, мало требовательны к плодородию и структуре почвы, обладает високой урожайностью, устойчивы к болезням и вредителям [3].

Актинидия очень неприхотливая растение, уход за ним довольно простой, поскольку актинидия почти невосприимчива к болезням, которые проявляются в результате неправильной посадки или агротехники выращивания.

Основным вредителями актинидии являются жуки-листопады, короеды, гусеницы паденицы, а болезнями - мучнистая роса, филлостиктоз, плодовая гниль, серая и зеленая плесень, вызываемы разного рода грибками [1].

В результате неправильного ухода за этим растением, лиана поражается мучнистой росой, которая проявляется с появлением на листье актинидии пятен черного цвета с фиолетовым ободком. Это - филлостикоз. Поврежденныи листья могут полностью опадать или становиться дырявым. Эта болезнь чаще всего поражает взрослые растения. На листьях актинидии часто появляются разноцветные налеты или же плесень, вызываемые также грибком, в результате чего на листьях возникают наросты, увеличивающиеся в размерах, вначале растение загнивает, а в скором времени погибает. Еще одно инфекционные заражения грибком заболевание актинидии - рамуляриоз листьев, в результате которого листовая пластина с обеих сторон покрывается пятнами.

Кроме листьев актинидии, болеют ее побеги и корни, их болезнь также вызвана грибком м носит название корневая гниль или фитофтороз. При этом заболевании растение теряет листву, ослабевает, его рост притупляется. В зоне корневой шейки образуются пятна из камодитечением, которые отличаются цветом от нормального. Кора актинидии в результате начинает трескается и отваливается. Эта болезнь возникает в результате неправильного полива, повышенной кислотности почвы, неправильного ухода.

Грибковые заболевание - серая гниль проявляется в том, сто пораженные болезнью места, приобретают окраску бурого цвета, покрываются серым налетом. Цветки актинидии, в результате заболевания сохнут и отпадают. Чаще всего болезнь поражает цветки, листья, побеги и ягоды растений. В начале на указанных органах растения появляются белый пушок грибницы (в виде белой ваты), а во время дождя на грибнице образуются склероции черного цвета и начинает распространятся грибок, который проникает через поврежденные места и инфицирует растение [1].

Кроме грибковых болезней актинидия страдает и от вредителей, например: червец небольшое насекомое до 5 мм, обитающее на листьях или побегах. Тело самки имеет овальную форму и пару крыльев. Насекомые откладывают яйца снизу листовой пластинки вдоль жилки листка, также насекомое выделяет пядь, где в дальнейшем развивается грибок, эти зараженные листья покрываются налетом белого цвета. Насекомые высасывают сок из растения, оно ослабевает и перестает развиваться. 
Жуки-листоеды относятся к одному из крупнейших семейств-жесткокрылых. Это обычно маленькие или средних размеров жуки от 3 до 15 мм, чаще всего яркой окраски: листоед лапландский, двадцатиточечный, краснокрылый и др. Их тело имеет яркую окраску: красную, зеленую, синюю. Интересная и характерная черта этих жуков в том, что они умеют прятать лапки и усики под себя так, что ни лап, ни усиков не видно, когда они сидят на листьях.

Пяденицы - это ночные бабочки с размахом крыльев до 50 мм разнообразной окраски и рисунка. Их гусеницы до 65 мм, всегда голые, имеют три пары грудных ног и всего две пары брюшных. Вот почему при движении они вынуждены подтягивать заднюю часть тела к передней, сильно выгибая спину, как бы измеряя поверхность пядями. Другая их характерная особеность в том, что они в случае опасности принимают позу, копирующую сучок, стебель, часть листа. Гусеницы объедают листья на протяжении всего лета.

Вредителями актинидии являются и жуки короеды. Эти жуки небольшого размера около 0,8 мм в длину, с достаточно крупной головой и тонкими лапками маленького размера. Они почти всю свою жизнь проводят внутри стволов деревьев. Проникая внутрь, жук протачивает ходы вглубь ствола, где находятся самые уязвимые участки проводящих тканей. Таких ходов один короед делает множества, чем причиняет вред дереву и нарушает обмен внутри его. В результате даже многие деревья, зараженные короедами, могут погибнуть буквально за один сезон.

С целью предотвращения заражений актинидии разными грибковыми заболеваниями и вредителями необходимо ранней весной обрабатывать лиану и почву вокруг нее бардоской жидкостью, что поможет избавится от личинок вредителей, зимующих в коре, в грунте, а осенняя оброботка актинидии и участка вокруг нее тем же препаратом уничтожить болезнетворных возбудителей и вредителей, устроившихся на зимовку. Пораженные листья, цветки и побеги необходимо удалять и сжигать [2].

Учитывая выше изложенное рекомендации, мы сможем ежегодно получать значительные урожаи нетрадиционных культур, в том числе и актинидии, которая украшает сад и в то же время дает необычные по вкусу и аромату полезные плоды, являющиеся источником витаминов и биологически активных веществ.

\section{Список использованных источников:}

1. Аблакатова А. А. Грибные болезни актинидии и лимонника в Приморском крае./ А.А.Аблактова Владивосток, 1960, т.6.В.4. с 184-190

2. Аблакатова А. А. К изучению патогенных грибов на лимоннике и видах актинидии. /А.А.Аблактова, Бюлл. Главн. бот. Сада 1961,В.- 42, с. 90-95

3. Скрипченко Н.В. Актинідія (сорти, вирощування, розмноження)./ Н.В.Скрипченко, Мороз П. А. - К.: Фітосоціоцентр, $2002-43$ с. 
Іванова Анастасія Олександрівна, магістр факультету хімії, біології і біотехнологій Донецький національний університет імені Василя Стуса, Україна

Науковий керівник: Березовський Ігор Васильович, канд. вет. наук, доцент кафедри зоології

Донецький національний університет імені Василя Стуса, Україна

\section{ЕХІНОКОКОЗ ЯК ГОСТРО ПАРАЗИТУЮЧА ХВОРОБА ЛЮДЕЙ І ТВАРИН}

Чим більше заглиблюєшся в тонкощі біології ехінокока, його епідеміологію і особливості перебігу ехінококозу різних органів, все більше і більше переконуєшся в дивовижною пристосовності і живучості цього паразита. Неминуче приходиш до висновку, що навряд чи коли-небудь це захворювання мимовільно повністю зникне 3 оточення людини і переліку його хвороб. Але чи означає це, що боротьба 3 ехінококоз безперспективна? Твердо можна сказати - ні! Ехінококоз, безсумнівно, треба відносити до розряду соціальних проблем у зв'язку з його великою поширеністю, тяжкістю наслідків ураження людини, величезними фінансовими витратами охорони здоров'я на його лікування.

При всій важливості проблеми фінансових витрат охорони здоров'я на лікування ехінококозу необхідно говорити про головні втрати - тяжкі ускладнення ехінококозу та високому їх відсотку у хворих, порівняно високої летальності при його хірургічному лікуванні, значному відсотку рецидивів захворювання при більшості сучасних методів лікування.

Накопичені на сьогодні наукою знання про проблему ехінококозу печінки у людини можна вважати досить великими. При їх ефективному використанні можна істотно поліпшити результати лікування цього захворювання. Основними шляхами поліпшення результатів лікування ехінококозу печінки можна вважати наступні: - профілактика поширення ехінококозу; - організація диспансерного спостереження «груп ризику» серед населення, перш за все, в ендемічних регіонах країни з метою максимально раннього виявлення ехінококозу печінки; за рахунок максимально раннього виявлення ехінококозу печінки впровадження в широку клінічну практику сучасних малоінвазивних методів лікування ехінококозу печінки; - у пацієнтів з пізніми стадіями перебігу ехінококозу печінки впровадження в практику відпрацьованих і апробованих ефективних методів хірургічного лікування ехінококозу.

Відомо, що типовий ланцюжком поширення ехінококозу є: вівці, свині, рідше велика рогата худоба, верблюди - собаки - людина. Собаки заражаються, поїдаючи нутрощі з ехінококовими кістами забитих тварин. У кишечнику собаки розвивається зрілий черв'як, його яйця забруднюють траву, землю, городні культури і знову потрапляють в кишечник овець та інших домашніх тварин, а потім їх печінка, легені і т.д., де і розвивається ехінококова кіста.

Людина може заразитися, гладячи собаку, або при вживанні в їжу забруднених овочів і інших порушеннях санітарії. Чітко уявляючи епідеміологію ехінококозу, неважко уявити собі і шляхи організації профілактики цього захворювання I все-таки, щодо профілактики ехінококозу доводиться, на жаль, констатувати, що бажаного його рівня в більшості регіонів країни, практично, 169 немає. Досвід цілого ряду країн показує, що там, де належним чином проводяться відповідні заходи, ехінококоз або взагалі переможений, або зустрічається дуже рідко. Так, у Великобританії ехінококоз зустрічається рідко, винятком є деякі райони Уельсу. Ехінококозу мало або взагалі немає в Ісландії, Голландії, Норвегії, країнах Північної Америки. При цьому треба відзначити, що в перерахованих 
країнах тваринництво, найважливіша ланка в ланцюжку епідеміології ехінококозу, розвинене досить значно. У 1996 році на II Всесвітньому міжнаціональному конгресі асоціації гепатопанкреатобіліарной хірургів в одній із доповідей було відзначено, що в Норвегії з 1982 року не відзначено випадків ехінококозу у людини. I цього вдалося домогтися, головним чином, широкомасштабними i чітко контрольованими профілактичними заходами - собакам 2-3 рази в рік співробітники відповідних служб безкоштовно і під відповідним контролем згодовують антигельмінтні препарати.

В Україні тваринництво завжди було i, ймовірно, завжди буде однією з основних галузей аграрного господарства. Отже, і основа для можливого поширення ехінококозу не зникне. Українцям не доводиться розраховувати на природні сприятливі ситуації природного зниження поширеності ехінококозу, як це має місце в деяких країнах. Наприклад, в Таїланді більше ніж за 70-річний період (3 1932 по 2004 роки) були опубліковані дані тільки про 9 випадків ехінококозу печінки у людини. І це знаходить своє пояснення в особливостях економіки і сільського господарства країни: в сільському господарстві - рисівник, обробіток кукурудзи; рибальство - інша основна галузь; лісове господарство, плантації каучуконосов і т.п. У тваринництві - переважно розведення буйволів, в меншій мірі свинарство, вівчарство - в довідковій літературі не згадується.

Без належної організації профілактики ехінококозу в Україні поширення цього важкого захворювання в ендемічних регіонах, можна вважати, не припиниться. Профілактика ехінококозу повинна починатися зі найсуворішого дотримання правил забою худоби, поховання і знищення уражених ехінококоз органів тварин. Необхідна наполеглива і постійна пропаганда знань про ехінококозі серед населення, як на селі, так і в містах, серед власників собак і мають 3 ними контакти. Одна 3 найважливіших цілей профілактики ехінококозу у людини це - усунення 3 циклу розвитку паразита основної ланки. А їм $\epsilon$ кінцевий хазяїн паразита - собаки. Відомі шляхи поширення ехінококозу через лисиць, вовків, шакалів і інших хижаків для зараження людини мають невелике значення, небезпека зараження людини від цих тварин невелика. Звичайно, мова не йде про вилучення собак з оточення людини, їх знищення. Але обов'язково має бути дотримано щорічне і багаторазове антигельмінтне його лікування, з досвіду інших країн. Безперечна i необхідність підвищення культури і санітарії утримання домашніх собак, про що нерідко, але, на жаль, безрезультатно, виникають дискусії в засобах масової інформації. Не менш важлива і проблема бездомних собак. Інше найважливіше напрям боротьби з ехінококоз людини - диспансерне спостереження за «групами ризику», перш за все працівниками тваринництва і сільського господарства, метою якого повинна бути рання діагностика ехінококозу.

Сьогодні для цього є ефективні, нешкідливі для людини і маловитратні методи дослідження, перш за все, ультразвукове дослідження. Населення, що відноситься до «групи ризику», має щорічно підлягати обстеженню органів черевної порожнини. Рання діагностика ехінококозу печінки дозволяє реалізувати програму широкого використання безпечних і ефективних методів лікування цього захворювання. Використання сучасної ультразвукової апаратури дозволяє впевнено діагностувати рідинні кістозні утворення в печінці від сантиметра і більше. Подальше обстеження таких пацієнтів доцільно проводити в спеціалізованих центрах, що мають досвід обстеження та лікування хворих з ехінококоз печінки. При невеликих кістах печінки, навіть ехінококкових, довгий час вважалося виправданим проводити динамічне спостереження і вдаватися до оперативного лікування при розмірах кіст більше 5 см. Сьогодні така позиція повинна бути переглянута. У хворих 3 невеликими ехінококовими кістами печінки відразу після встановлення діагнозу доцільно починати хіміотерапію альбендазолом. На нашу думку, це можуть бути кісти діаметром до 3-4 см. При кістах більшого діаметра необхідно проведення комбінованого лікування, що включає в себе хіміотерапію альбендазолом і подальше малоінвазивне втручання у вигляді 
раж-методу або раж + дренування кісти. Зі сказаного випливає велика значимість точного встановлення паразитарної природи невеликих кіст печінки, коли сонографические ознаки ехінококозу не завжди бувають виразними. У цих випадках істотну допомогу може надати лабораторна діагностика ехінококозу i вона повинна проводитися для вироблення обгрунтованого оптимального плану лікування цього захворювання. В останні роки найбільш інформативним, на наш погляд, в цьому плані можна вважати дослідження концентрації ехінококкових антитіл в сироватці крові (імуноферментний аналіз - ІФА). При підвищенні концентрації більш ніж 1: 100 можна з великою часткою ймовірності вважати такий результат характерним для ехінококозу. Хіміотерапія при ехінококозі до недавнього часу вважалася малозначущими методом лікування. Це, звичайно, було пов'язано з тим, що в медичній практиці не було достатньо ефективних засобів пригнічення росту цього паразита у людини.

Висновки. Отже, апробований на сьогодні альбендазол можна вважати порівняно ефективним препаратом для лікування ехінококозу, хоча можна впевнено говорити, що пошуки більш ефективних препаратів необхідні, вони будуть продовжуватися i, можна сподіватися, увінчаються успіхом. Поки що в своїй практичній діяльності хірургам при вирішенні питання про розробку оптимальної схеми лікування ехінококозу печінки доцільно виходити з положення про необхідність проведення комбінованого лікування, що включає в себе хіміотерапію альбендазолом і подальше хірургічне втручання від малоінвазивного пункційного методу до традиційної хірургічної операції.

\section{Список використаних джерел:}

1. Островский В. М. Эхинококковая болезнь // Энциклопедический словарь Брокгауза и Ефрона : в 86 т. (82 т. и 4 доп.). - СПб., 1890-1907.

2. Дейнека И. Я. Эхинококкоз человека. - М.: Медицина, 1968. - 376 с.

3. Геллер И. Ю. Эхинококкоз: Медико-экологическое аспекты и пути ликвидации инвазии. - М.: Медицина, 1989. - 208 c.

4. World Health Organization/WHO/CDS/CSR/APH/2001.6 — PAIR: Puncture, Aspiration, Injection, ReAspiration. An option for the treatment of Cystic Echinococcosis 


\section{СЕКЦІЯ 6.}

\section{МЕДИЧНІ НАУКИ}

DOI 10.36074/29.05.2020.v2.03

Лісова Слизавета Миколаївна

здобувач вищої освіти І медичного факультету

Харківський національний медичний університет, Украӥна

Шарун Сабіна Нурадінівна

здобувач вищої освіти I медичного факультету

Харківський національний медичний університет, Украӥна

Науковий керівник: Овчаренко Ірина Анатоліївна, асистент кафедри фтизіатрії та пульмонології

Харківський національний медичний університет, Україна

\section{АНАЛІЗ ДИНАМІКИ ЗАХВОРЮВАНОСТІ НА НОВІ ВИПАДКИ ТА РЕЦИДИВИ ТУБЕРКУЛЬОЗУ У ХАРКІВСЫКІЙ ОБЛАСТІ ЗА 5 РОКІВ}

Актуальність. Захворюваність на туберкульоз залишається однією з актуальних проблем охорони здоров'я в Україні та у всьому світі [1]. Захворюваність на туберкульоз $\epsilon$ одним 3 найважливіших індикаторів соціально-економічного становища країни та рівня надання медичної допомоги. Туберкульоз продовжує завдавати людству економічних збитків і нести більше життів, ніж будь-яке інше інфекційне захворювання, тому одним 3 пріоритетних напрямків охорони здоров'я Україні є боротьба з туберкульозом [2].

Мета: проаналізувати динаміку захворюваності на вперше виявлений туберкульоз і рецидиви у Харківській області, та порівняти отримані результати 3 відповідними по Україні за 2014-2018 роки.

Матеріали і методи: нами були опрацьовані аналітико-статистичні матеріали [1], оприлюднені на сайті Центру Громадського Здоров’я МО3 України, отримані з форми № 8 "Звіт про захворювання на активний туберкульоз", отримані впродовж 2014-2018 років в розрахунку на 100 тис. населення.

Результати та їх обговорення. Протягом останніх 5 років поступово знижуються показники захворюваності на туберкульоз легень. У 2018 захворюваність знизилась на 19,8 \% (від 70,2 випадків на 100 тис. нас. у 2014 році до 56,3 випадків на 100 тис. нас. у 2018 році). Відповідні показники в Харківській області за 2018 рік є нижчими на 19,2 \%: 45,5 випадків на 100 тис. нас. у Харківській області проти 56,3 випадків на 100 тис. нас. в Україні. Динаміка захворюваності продемонстрована на рис. 1.

Станом на 2018 рік кількість хворих на первинний туберкульоз складала 39,8 на 100 тис. нас. у Харківській області, що є 21,2 \% менше, ніж по Україні (50,5 на 100 тис. нас). Первинна захворюваність, відповідно до загальної, також поступово зменшується.

В Україні за останні роки спостерігається зниження частки рецидивів туберкульозу легеневої та позалегеневої локалізації: від 14,6 випадків на 100 тис. нас. у 2015 році до 11,8 у 2018 році (на 19,2 \% нижче). Найменший показник був у 2014 році - 11,7 випадків на 100 тис. нас.. Щодо Харківської області, то кількість рецидивів туберкульозу є значно нижчою, порівнюючи з загальноукраїнською. Загалом показник рецидивів є сталим: у 2015 році дорівнював 9,9 випадків на 100 тис. нас., у 2016 - 9,5 на 100 тис. нас., у 2017 - 8,5 на 100 
тис. нас. та у 2018 - 9,9 на 100 тис. нас.. Знову найнижчий показник спостерігався у 2014 році - 6,6 випадків на 100 тис. нас..

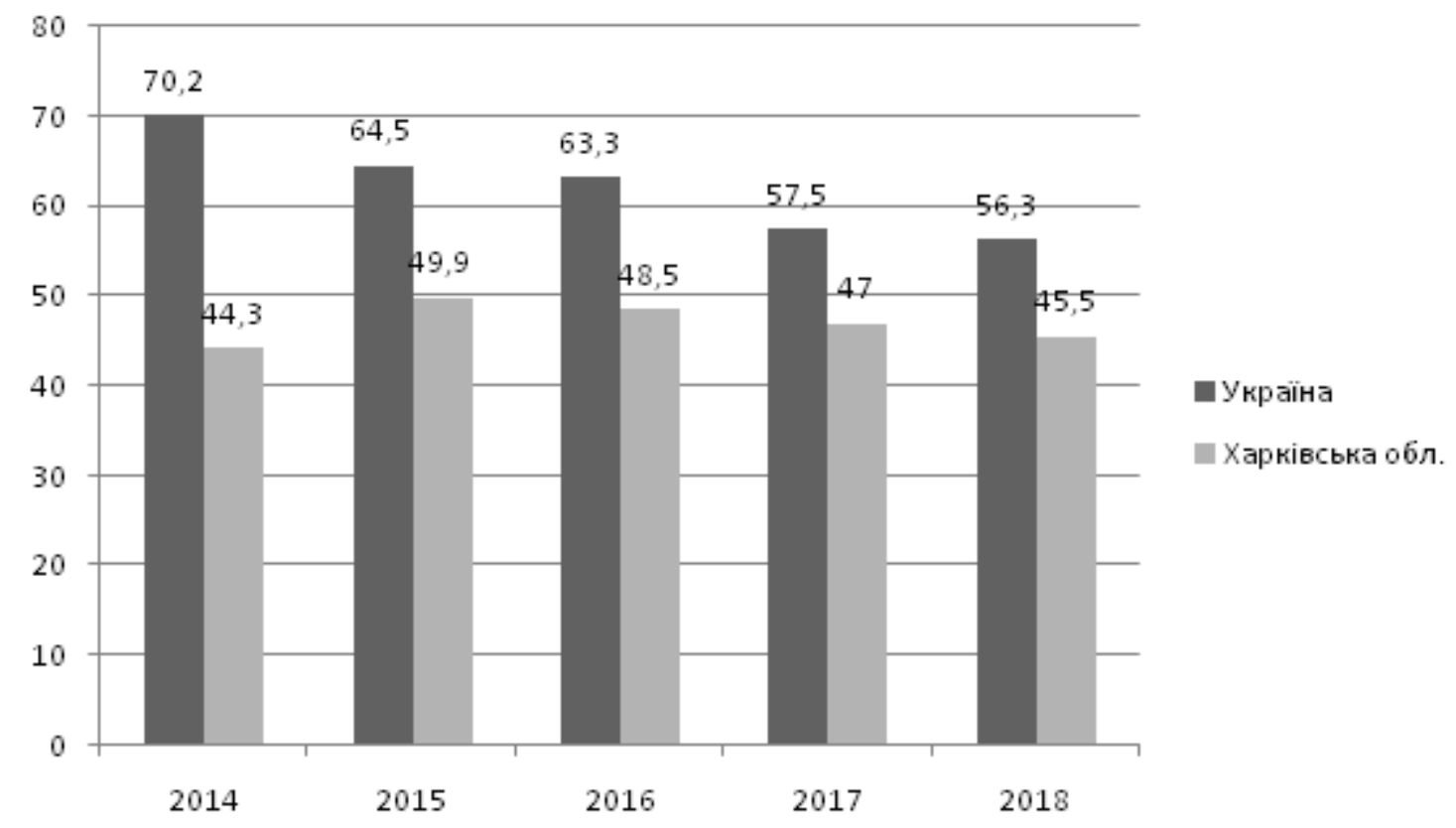

Рис. 1. Порівняльна динаміка захворюваності на туберкульоз легень (нові випадки та рецидиви) серед усього населення України та Харківської області за 2014-2018 рр.

Джерело: побудовано авторами за даними [1].

Дана тенденція пояснюється тим, що відбувається закупівля протитуберкульозних засобів на державному рівні; реалізуються загальнодержавні програми протидії захворюванню; підвищується охоплення населення профілактичними оглядами на туберкульоз; впроваджуються сучасні методи діагностики туберкульозу і як наслідок знижується частка запущених форм туберкульозу серед вперше виявлених хворих на туберкульоз.

Висновки: В Україні ситуація з туберкульозом починає стабілізуватись. Протягом останніх чотирьох років захворюваність знизилась на 19,8 \%, а також відзначено поступове зниження захворюваності приблизно на 4 \% щорічно у період з 2013 по 2018 рр.. У період з 2015 р. по 2018 р. відбулось зниження кількості зареєстрованих випадків повторного лікування. Показники захворюваності в Харківській області є значно нижчими, ніж відповідні по Україні.

\section{Список використаних джерел:}

1. Туберкульоз в Україні: аналітико-статистичний довідник за 2018 рік. - Київ, 2019. - 45 с. // Режим доступу: https://phc.org.ua/sites/default/files/users/user90/TB_surveillance_statistical-information_2018_dovidnyk.pdf (Дата звернення: 01.05.2020).

2. Уніфікований клінічний протокол первинної, вторинної (спеціалізованої) та третинної (високоспеціалізованої) медичної допомоги «Туберкульоз» (2014) // Режим доступу: https://dec.gov.ua/wpcontent/uploads/images/dodatki/2014_620_TB/2014_620_YKPMD_TB.pdf (Дата звернення: 01.05.2020).

3. Support to Ukraine in Implementing its National TB Program// Режим доступу: http://www.path.org/publications/fles/CP_ukraine_tb_fs.pdf (Дата звернення: 01.05.2020). 
Аксенкова Сусанна Минівна, здобувач вищої освіти другого медичного факультету Харківський національний медичний університет, Украӥна

Науковий керівник: Тимошенко Галина Юріївна, асистент кафедри внутрішньої медицини №3 та ендокринології Харківський національний медичний університет, Україна

\section{ВИБІР ПОЧАТКОВОЇ АНТИГІПЕРТЕНЗИВНОЇ ТЕРАПІЇ У ПАЦІЕНТІВ 3 АГ 1СТУПЕНЯ}

Актуальність. Згідно 2013 ESH/ESC Guidelines for the management of arterial hypertension в якості початкової терапії для пацієнтів с АГ 1 ступеня вважалося допустимим використання монотерапії. Однак у 2018 в оновлених рекомендаціях акцентовано увагу на застосуванні ініціальної подвійної терапії для лікування всіх ступенів АГ [1]. У якості початкового лікування на першому етапі використовують комбінацію іАПФ або БРА + АК або ТД. Згідно 3 останніми дослідженнями найбільш тривалий та стійкий ефект 3 мінімальним розвитком побічних дій є комбінація телмісартану (БРА) з амлодіпіном (АК) [2], однак постає питання про ефективність та особливості застосування даної схеми як початкової терапії для хворих з м'якою АГ.

Мета роботи. Провести оцінку початкової терапії подвійною комбінацією БРА + АК у пацієнтів з АГ 1 ступеня на основі швидкості досягнення цільового АТ та частоти виникнення побічних реакцій.

Матеріали та методи. Проведено аналіз терапевтичного лікування 43 хворих на базі Обласної клінічної лікарні міста Харків. Середній вік (СВ) склав 55,85 $\pm 2,09$ року, серед них жінок $-42 \%$, чоловіків - 58\%. Перед початком дослідження учасники дали письмову інформовану згоду. Середнє значення офісного АТ всієї групи досліджуваних: САТ / ДАТ - 155,88/ 92,59 \pm 1,53 / 1,43 мм рт. ст. Згідно з 2018 ESH/ESC Guidelines for the management of arterial hypertension у всіх досліджуваних встановлено АГ 1 ступеня. Усі хворі приймали подвійну терапію БРА + АК (генеричний препарат хіпотел (телмісартан) 40-80 мг 1 раз на добу та амлодіпін (амлодіпін) 2,5 -5 мг 1 раз на добу). Доза кожного препарату встановлювалася індивідуально для кожного пацієнта, враховуючи супутні захворювання, IMC, вік та загальний стан. Критерії включення у дослідження: діагностована АГ 1 ступеня, вік від 18 до 75, відсутність протипоказань до використовуваних препаратів. Цільовий АТ згідно з сучасними рекомендаціями становить < 140/90 мм рт. ст. у всіх пацієнтів з гарною переносимістю терапії, а для більшості < 130/80 мм рт. ст. Для пацієнтів віком $<65$ рекомендований рівень САД -120 - 129 мм рт. ст. Оцінка результатів лікування проводилася на другий та на четвертий тижні лікування.

Результати. Моніторинг офісного АТ на другий тиждень дослідження встановив:

-зниження САТ на 9,3 $\pm 1,09$ мм рт.ст.

-зниження ДАТ на 4,7 $\pm 1,74$ мм рт.ст.

-середній АТ складав 146, 58/ 87,89 мм рт. ст.

-побічних дій препаратів або зміни стану пацієнтів, що зумовлювали перегляд схеми лікування не спостерігалося.

Моніторинг офісного тиску на четвертий тиждень встановив:

-зниження САТ на 16,4 $\pm 1,39$ мм рт.ст.

-зниження ДАТ на $8,7 \pm 1,03$ мм рт.ст. у порівнянні з контрольними значеннями на початку дослідження.

-середній АТ склав 139,48/ 83,89 мм рт. ст. 
-у 1 пацієнта (2,32 \%) через 1 місяць лікування (хіпотел 80 мг та амлодіпін 2,5 мг на добу) виникли стомлюваність, запаморочення, біль в очах, що було пов'язано 3 неадекватним контролем АТ через 1 місяць терапії. Це зумовило перегляд призначених доз та корекцію схеми лікування.

Висновки. Лікування хворих артеріальну гіпертензію 3 подвійною комбінацією препаратів має суттєвий вплив на клінічну практику та покращує якість лікування даних пацієнтів. Вже на 4 тиждень було досягнуто цільових значень АТ, що дозволяє розглядати комбінацію хіпотелу та амлодіпіну як препарати вибору при АГ 1 ступеня.

\section{Список використаних джерел:}

1. Williams B., Mancia G., Spiering W. et al.; ESC Scientific Document Group (2018) 2018 ESC/ESH Guidelines for the management of arterial hypertension. Eur. Heart J., 39(33): 3021-3104.

2. Takagi, H., Niwa, M., Mizuno, Y. et al. A meta-analysis of randomized trials of telmisartan versus losartan for reduction of ambulatory blood pressure. Hypertens Res 36, 959-966 (2013). https://doi.org/10.1038/hr.2013.78

Мимренко Анастасія Анатоліївна, студентка 5 курсу Медичного факультету ДВНЗ "Ужггородського національного університету", Украӥна

Науковий керівник: Палко Аліса Іванівна, канд.біол.наук, доцент кафедри соціальної медицини та гігієни

ДВНЗ "Ужггородського національного університету", Україна

\section{ВИВЧЕННЯ РІВНЯ ОБІЗНАНОСТІ СТУДЕНТІВ ВИЩИХ НАВЧАЛЬНИХ ЗАКЛАДІВ УКРАЇНИ ЩОДО ПРОФІЛАКТИКИ, ШЛЯХІВ ПЕРЕДАЧІ ТА ЛІКУВАННЯ ВІЛ-ІНФЕКЦЇ̈ ТА ОЦІНКА СТИГМИ ЩОДО ВІЛ- ІНФІКОВАНОГО НАСЕЛЕННЯ}

Вступ. На сьогоднішній день ВІЛ-інфекція набула глобальних масштабів і становить реальну загрозу соціально-економічному розвитку більшості країн світу. За даними інформаційного бюлетеня UNAIDS з початку епідемії ВІЛ-інфекції в світі 76,1 млн людей були інфіковані ВІЛ, близько 35 млн. - померли від захворювань, пов'язаних з ВІЛ та ще близько 37 мільйонів людей живуть 3 даною інфекцією. За оціночними даними на початок 2018 року в Україні проживало 241 тисяча ВІЛ-інфікованого населення. Рівень поширеності вірусу у віковій групі 15-49 років становив 0,98\%. Територіальне поширення ВІЛ-інфекції в Україні нерівномірне. Найбільш інтенсивно епідемічний процес даного захворювання протікає у південних регіонах України, а в західних областях держави рівні поширеності ВІЛ-інфекції найнижчі [1]. Обізнаність молоді щодо шляхів передачі ВІЛ та заходів профілактики ВІЛ/СНІДу $є$ надзвичайно важливим критерієм у боротьбі 3 поширенням епідемії, адже саме ця вікова категорія населення є групою підвищеного ризику щодо поширення даної інфекції в популяції. 3 кожним роком спостерігається підвищення інтенсивності стигми та соціальної дискримінації щодо ВІЛ-позитивних людей з боку сучасної молоді [3]. За даними досліджень UNAIDS було встановлено, що більша частина людей, які є ВІЛ-інфікованими втратили роботу, що пов'язано з їх ВІЛ-статусом. Також ВІЛ-інфікованим особам категорично відмовляють у прийомі на роботу [2]. До 35\% осіб повідомили о наявності дискримінації по відношенню до себе з боку вчителів. 45\% досліджуваних повідомляють про прояви дискримінації у вигляді образ та погроз зі 
сторони людей, які проживають поруч. 85\% ВІЛ-інфікованих людей внаслідок дискримінації вирішили не народжувати більше дітей [4].

Мета. Оцінити рівень обізнаності студентів ВНЗ України щодо профілактики, шляхів передачі та лікування ВІЛ-інфекції. Вивчити рівень інтенсивності стигми серед студентів українських ВНЗ щодо ВІЛ-інфікованих людей в порівнянні з країнами СС.

Матеріали та методи. Проведено онлайн анкетування (кореспондентним методом) серед студентів вищих навчальних закладів України. У дослідженні прийняли участь студенти з 6 ВНЗ на території України. Статистична обробка даних виконана за допомогою сервісу Google Forms та пакету Microsoft Office Excel, v-2010, n= 153, частка чоловіків $26,8 \%$, частка жінок $-73,2 \%$.

Результати досліджень. На основі отриманих даних було встановлено, що 61,4\% респондентів вважають свої знання щодо ВІЛ достатніми і це підтверджується високим рівнем обізнаності щодо профілактики, шляхів передачі та лікування ВІЛ-інфекції. За даними анкетування лише $25 \%$ респондентів вважають, що ВІЛ-інфекція виліковна. Також було встановлено наявність високого рівня стигми щодо ВІЛ-інфікованих, про що свідчать наступні результати: кожен третій вважає, що лікар, інфікований ВІЛ, за жодних умов не може працювати у даній сфері, незалежно від спеціальності. 26.5\% анкетованих не будуть проживати поряд з ВІЛ-інфікованими людьми. Наявність стиглих у опмтуваної частки студентів ВНЗ України становить 92,2\%, порівняно з даними за 2017 рік у країнах СС становить 67,4\%, у Латинській Америці - 45,6\%, у США - 85,2 \%. Було виявлено високий рівень обізнаності студентів щодо шляхів передачі, лікування та профілактики ВІЛінфекції, і саме частка осіб, які були найбільш обізнаними у цьому є стигмованими. Вони вважають, що ВІЛ-інфіковані особи не можуть мати дітей, працювати у освітніх закладах та медичній сфері, та не хотіли би проживати поруч з ВІЛ інфікованими особами.

Висновки. Студенти ВНЗ показали високій рівень обізнаності про способи передачі, профілактику та лікування ВІЛ-інфекції. Не зважаючи на даний факт, серед опитаних було виявлено високий рівень стигми, що має великий вплив на поведінкові реакції та рівень толерантності щодо ВІЛ-позитивних людей. Рівень обізнаності респондентів щодо шляхів передачі та профілактики ВІЛ жодним чином не впливає на поширеність та рівень стигматизму щодо інфікованого населення. Відсоток поширеності стигми серед студентів України не залежить від їхньої сфери діяльності, факультету та спеціальності, за якими вони навчались на момент проведення дослідження.

\section{Список використаних джерел:}

1. Інформаційний бюлетень. Епідемічна ситуація з ВІЛ-інфекції в Україні станом на 01.01.2018 р. (2018). 4 c. -Вилучено iз https://phc.org.ua/uploads/documents/83da57/5bc7bd744850ae49ad733 3e92a0ddc1e.pdf

2. Інформаційний бюлетень. UNAIDS DATA $2018 . \quad$ (2018). Вилучено 3 http://www.unaids.org/sites/default/files/media_asset/unaids- data-2018_en.pdf

3. Слабкий Г.О., Миронюк І.С., Білак-Лук'янчук В.Й., Кручаниця В.В.. (2016). Подолання стигми та дискримінації до людей, що живуть з ВІЛ. Методичні рекомендації. Київ.

4. Global AIDS monitoring 2018: indicators for monitoring the 2016 United Nations Political Declaration on HIV and AIDS. Geneva: UNAIDS. (2018). Вилучено 3 http://www.unaids.org/sites/default/files/media_asset/2017Global-AIDSMonito ring_en.pdf 
Стоян Анна Олегівна, здобувач вищої освіти медичного факультету, Харківський національний медичний університет, Украйна

Колесник Марія Романівна, здобувач вищої освіти медичного факультету, Харківський національний медичний університет, Украӥна

Науковий керівник: Овчаренко Ірина Анатоліївна, асистет кафедри фтизіатрії та пульмонології

Харківський національний медичний університет, Украӥна

\section{ВИВЧЕННЯ ЕПІДЕМІЧНИХ ПАРАМЕТРІВ РОЗПОВСЮДЖЕННЯ ТУБЕРКУЛЬОЗУ ТА ЙОГО ПРОФІЛАКТИКИ}

Актуальність. На сьогоднішній день туберкульоз $\epsilon$ важливим епідемічним та соціально-небезпечним інфекційним захворюванням.У сучасному світі зареєстровано близько однієї третини населення, яка інфікована туберкульозом. Кожного року приріст захворювання на туберкульоз збільшується у середньому на 8 мільйонів осіб. Загальна кількість хворих на туберкульоз у світі сьогодні доходить до 60 мільйонів, а інфікованих близько третини населення планети.

Мета. Вивчити епідемічні параметри поширення туберкульозу та його профілактики.

Виклад матеріалу. Згідно 3 оцінками, в 2018 р у всьому світі на туберкульоз захворіло 10 мільйонів чоловік (діапазон значень 9,0-11,1 мільйона), і цей параметр останнім часом залишається на порівняно стабільному рівні. Тягар захворювання варіюється в великих межах залежно від країни, від менш п'яти до понад 500 нових випадків на 100000 населення в рік, а глобальне середнє значення становить приблизно 130. Тягар туберкульозу зачіпає осіб обох статей у всіх вікових групах, але найбільш велике серед чоловіків (у віці 15 років і старше), на частку яких в 2018 р довелося 57\% всіх випадків захворювання на туберкульоз. Частка жінок, для порівняння, склала 32\%, а дітей (у віці молодше 15 років) - 11\%. Частка осіб, які живуть з ВІЛ, в загальній масі пацієнтів 3 туберкульозом склала 8,6\% [2].

Територіально більшість випадків захворювання на туберкульоз в 2018 р відбулося в таких регіонах ВОО3, як Південно-Східна Азія (44\%), Африка (24\%) і Західна частина Тихого океану (18\%); менша частка випадків припала на Східне Середземномор'я (8\%), Американський (3\%) і Європейський (3\%) регіони. Дві третини глобального сукупного показника припало на вісім країн: Індію (27\%), Китай (9\%), Індонезію (8\%), Філіппіни (6\%), Пакистан (6\%), Нігерію (4\%), Бангладеш (4\% ) і Південну Африку (3\%). У цих та 22 інших країнах, що входять в складений ВООЗ список з 30 країн 3 високим тягарем туберкульозу, було зареєстровано 87\% всіх випадків захворювання в світі [4].

Високе поширення туберкульозу по всьому світу зачіпає основні проблеми, які пов'язані з його профілактикою. Основним заходом охорони здоров'я, що дозволяє знизити ризик переходу туберкульозної інфекції в активну форму хвороби, $є$ профілактична терапія туберкульозу. Додатковий захист, особливо від важких форм туберкульозу у дітей, забезпечує проведена в дитячому віці вакцинація бацилами Кальмета-Герена (БЦЖ). Відповідно випущеному в 2018 р керівництву ВООЗ, профілактичне лікування туберкульозної інфекції рекомендується особам, що живуть з ВІЛ, особам, які на побутовому рівні контактують 3 хворими у яких бактеріологічно підтверджений туберкульоз, і особам, що входять до груп ризику по причині свого клінічного статусу [3]. 
У 2018 р значно зменшилася кількість осіб, які починають профілактичне лікування. Це відбувається через побутові контакти з хворими на туберкульоз. Наразі 349487 дітей у віці молодше п'яти років (на 20\% більше в порівнянні з 292182 дітьми в 2017 р), що відповідає 27\% від 1,3 мільйона дітей, які, згідно з оцінками, на сьогоднішній день відповідають критеріям профілактики. Крім того, ще 79195 осіб в інших вікових групах (на 30\% менше в порівнянні з 103344 в 2017 р) також потребують хіміопрофілактики. Досягнення цільових показників, встановлених на нараді високого рівня ООН, потребують значного розширення масштабів роботи. У 2018 року про проведення вакцинації БЦЖ в якості стандартного компонента програми імунізації дітей повідомили 153 країни. 3 них, 113 країноцінили охоплення такою вакцинацією на рівні вище $90 \%$ [1].

Висновки. Тенденція до поширення туберкульозу залишається постійною i характеризується інтенсивним зростанням. Основним заходом охорони здоров'я, що дозволяє знизити ризик переходу туберкульозної інфекції в активну форму хвороби, $\epsilon$ профілактична терапія туберкульозу. За умови своєчасної діагностики хвороби та проведення шестимісячного курсу лікування антибіотиками першої лінії більшість хворих на туберкульоз можна вилікувати і перервати подальшу передачу інфекції. Такі заходи, як скорочення поширеності загрожують здоров'ю і сприяють розвитку туберкульозу факторів ризику, організація профілактичного лікування осіб 3 латентною туберкульозною інфекцією та прийняття багатосекторальних заходів впливу на ширші детермінанти туберкульозної інфекції та захворюваності дозволяють зменшити щорічну чисельність нових випадків захворювання на туберкульоз і, відповідно, кількість смертей від нього.

\section{Список використаних джерел:}

1. Global tuberculosis report (2019).

2. Доповідь про глобальну боротьбу з туберкульозом (2014). Москва: ВООЗ.

3. Аксьонова, В. А. (2017). Особливості туберкульозу у дітей в XXI столітті, досягнення і перспективи в області профілактіки і діагностики (с.58-62).

4. Гайдаров, Г. М. (2017). Інтегральна оцінка епідемічної ситуаціі з туберкульозу та вплив медикоорганізаційних факторів на іiі розвиток. (с139-143).

Матрьонін Андрій Романович, здобувач вищої освіти медичного факультету Державний заклад «Луганський державний медичний університет», Украйна

\section{ВИНИКНЕННЯ ІНФЕКЦЙНИХ ОСЕРЕДКІВ У ПОБУТІ}

Існування будь-якої живої істоти, безумовно, супроводжується зміною оточуючого середовища у результаті іiі життєдіяльності та створення особливих умов, які можуть використовувати інші живі істоти. У даній роботі, буде звернено увагу на ланцюг взаємовідносин «бактерія-людина», роль людини у створенні сприятливих умов для патогенних мікроорганізмів.

Мета роботи: узагальнити інформацію про виникнення інфекційних побутових хвороб та роль гігієни у їх запобіганні. Визначити, які мікроорганізми та яким чином людина може культивувати у побуті. Обгрунтувати гігієнічні норми.

Дослідження даної теми неможливе без аналізу вже набутих знань з мікробіології та гігієни ( Гайдаш І.С., Флегонтова В.В., Саллі Ф. Блумфільд, Кумар Дж. Нат та інтернет ресурси).

Найпоширенішими патогенними мікроорганізмами у людському побуті є бактерії наступних видів: Salmonella enterica, Escherichia coli, Staphylococcus aureus, Listeria monocytogenes. 
Salmonella enterica - pухомі факультативно-анаеробні грамнегатівні палички, які здатні паразитувати у кишечнику багатьох видів хребетних тварин й інфекціювати людей, приводячи до розвиту гострого ентериту чи сальмонельозу. Найчастіше за все, ця бактерія потрапляє до дому у сирих курячих чи гусячих яйцях, майонезі, печиві та інших кондитерських виробах. Сальмонели можуть довгий час зберігатися у оточуючому середовищі та розповсюджуватися домашніми тваринами та людиною практично по всій оселі. На це вказують дослідження сумки пилососів. Окрім холодильника, Сальмонели здатні розмножуватися у ванних кімнатах, зокрема на вологих ганчірках. Основними клінічними проявами є нудота, пронос, біль у животі, підвищення температури. Чутливі до дезінфікуючих засобів, кип’ятіння викликає їх раптову загибель [1]

Escherichia coli - рухомі факультативно-анаеробні грамнегативні паличкоподібні бактерії, які є мешканцями нормальної мікрофлори кишечнику людини, однак, через мутації виникають патогенні штами, які на фоні ослаблення організму, здатні викликати гастроентерит, сепсис, менінгіт перитоніт, мастит, та грамнегативну пневмонію. Зазвичай, найчастіше місце, де знаходяться патогенні штами кишечної палички є предмети, які знаходяться біля унітазу, особливо ті предмети, які не мають щільної структури ( рушники, зубні щітки, мочалки і т.д). Під дією 5\% фенолу, 3\% формаліну та інших дезінфікуючих засобів, гинуть через декілька хвилин. При кип’ятінні - миттєво [1].

Staphylococcus aureus - це шароподібні грампозитивні бактерії, які викликають багато патологій, таких як пневмонію, менінгіт, абсцес, фурункули та флегмони. Приблизно 20-40 \% людей є носіями цієї бактерії, яка може зберігатися на кожних покровах та слизистих оболонках. Стафілококи відносно резистентні до холоду, висиханню, дії сонячних променів, та, що особливо, до дії хімічних речовин [4]. В оселі вони можуть знаходитись на засобах особистої гігієни ( рушниках, зубних щітках, мочалках і т.д). В середньому, дезінфікуючи засоби вбивають золотистого стафілокока за 15-30 хвилин. При кип'ятінні гинуть миттєво [1].

Listeria monocytogenes - рухома грампозитивна паличка, збудник лестеріозу. Має гігієнічне значення бо є сапронозом (може жити на неживих об'єктах). Її високу стійкість до оточуючого середовища обумовлюють психрофільність та термотолерантність. У дім потрапляє через продукти харчування, зокрема неправильно пастеризоване молоко, сир, зіпсоване морозиво, м'ясо [3]. Далі може залишатися на будь-яких поверхнях та інфікувати.

Викликає харчові інфекції, захворювання нервової системи , септичні прояви, мастити. Від дезінфікуючих засобів гинуть через 15-30 хвилин, від кип'ятіння - миттєво.

Отже, розповсюдження бактерій у жилих приміщеннях це результат поєднання фекально-орального механізму їх передачі зі здатністю виживати в умовах, створених людиною. Особливу увагу слід звернути на холодильник, через його сприятливий температурний режим та наявність поживних речовин, на ванну кімнату з унітазом та оточуючі його засоби особистої гігієни. Ванна кімната характеризується вологістю , великою кількістю пористих об'єктів, на які здатні осідати бактерії [6]. Також важливою 3 точки зору гігієнічного контролю $є$ кухонне приміщення. Через сприятливу температуру, постійну вологість та наявність харчових залишків, бактеріальними вогнищами можуть стати кухонні губки, дошки для нарізання їжі, ганчірки [5]. Найчастіше, бактерії які мешкають в оселі людини, викликають харчові токсикоінфекції, гастроентерити тощо. Гинуть приблизно через пів години після дезінфекції та миттєво після кіп'ятіння.

Спираючись на вищезгадане, можна зазначити основні ланки ланцюга взаємовідносин «бактерія-людина»: - для виникнення інфекційного осередка потрібне джерело мікробів, яким найчастіше є їжа, вода, людина;

- наявність «вихідних воріт» - через контакт їжі з руками, випорожнення, кашель; - поширення мікробів домівкою, їх осідання на місцях, зі сприятливими умовами; 
- наявність «вхідних воріт» - це можуть бути слизові оболонки травних та дихальних шляхів;

- наявність групи ризику ( людей, з ослабленим імунітетом, дітей та літніх людей) [2].

Окрім бактерій, людина може створювати сприятливе середовище для розвитку грибів, які здатні викликати мікози [2]. Найпоширенішими у людському побуті патогенними грибами є Aspergillius niger та рід Trichophyton.

Aspergillius niger - це вид віщих плісеневих грибів, які здатні викликати у людини та тварин небезпечні захворювання - аспергильозі [2]. Вони можуть з'являтися в усіх вологих місцях оселі, найчастіше це ванна кімната, пластикові вікна. Окрім вологості, для їх розвитку необхідна достатня температура, затемнення поміщення, та пористість поверхні росту. Захворювання виникає через вдихання спорових форм гриба. Аспергильоз може викликати серйозні ураження внутрішніх органів, які можуть проявлятися у вигляді туберкульозу, саркоідозу, печінкової та ниркової недостатності. Початкові симптому можуть буди у вигляді задишки, кашлю, лихоманки.

Отже, аспергильози виникають через недотримання гігієнічних норм, щодо вологості приміщень, температури та вентиляції. Особливу увагу слід звернути на розміщення матеріалу, який добре поглинає вологу, наприклад, гіпсокартону. Проблема вентиляції частіш за все обумовлена герметичністю пластикових вікон, які перешкоджають потоку повітря. Розміщення гіпсокартону у вологих місцях спричиняє поглинання ним води та, як наслідок, розмноження грибків [2]. Для дезінфекції можна використовувати хлорку, пероксид водню, уксус, гіпохлорид натрію.

Рід Trichophyton - включає гриби-дерматофіти, які викликають оніхомікоз- ураження нігтя. Гриби роду Трихофітон можуть розвиватися у вологих містах : ванних кімнатах, банях, але найчастіше вони з'являються у взутті, зокрема низької якості, яке не здатне пропускати повітря та сприяє потовиділенню. На кожні покрови трихіфітони потрапляють через контакт шкіри з зараженим предметом, спочатку гриб розповсюджується на шкіру ніг чи рук, а потім уражує нігтьову пластинку, викликаючи такі іiї зміни : тьмяність, пожовтіння, втрата блиску, свербіж, почервоніння, злущування шкіри, розшарування нігтя, його крихкість та неприємний запах. Особливо схильні до охіномікозу люди, які страждають на варикоз, гіпергідроз та захворювання крові.

Профілактика грибів-дерматофітів полягає в дотриманні правил особистої гігієни у суспільних банях , на пляжах, зонах відпочинку, контроль за станом взуття. Також важливою є дезінфекція полу, дерев'яних об'єктів, які знаходяться у вологому місці, дезінфекція басейнів та медичні огляди, лікування хворих.

Таким чином, можна зробити висновок, що етіологія багатьох інфекційних захворювань може бути наслідком неадекватної домашньої гігієни, яка поєднує у собі: - харчову гігієну, тобто правильну термічну обробку їжі, іiі збереження, а також безпечну утилізацію харчових відходів;

- дотримання правил особистої гігієни. До цього окрім миття рук, відноситься користування інструментами особистої гігієни, такими як рушник, зубна щітка, мочалка. Це обумовлено тим, що кожна людина має свою унікальну мікрофлору та може бути носієм збудника інфекції;

- загальну гігієну ( миття підлог, дезінфекція ванних приміщень, миття холодильних приладів і т.д). Це важливо, бо бактерії мають деяку резистентність до факторів оточуючого середовища, тому щоб запобігати їх розмноженню, треба слідкувати за станом приміщень; - догляд за домашніми тваринами, які потенціально можуть носіями інфекцій. Через це необхідно регулярно перевіряти тварин у ветеринара; - профілактика розповсюдження комах, які можуть переносити патогенні мікроорганізми; - своєчасне виявлення та лікування хворих, їх ізоляція з дотриманням санітарних норм [2]. 


\section{Список використаних джерел:}

1. Гайдаш. І.С, Флегонтова В.В (2004). Мікробіологія, вірусологія та імунологія.(101-165). Луганськ. [російська].

2. Саллі Ф. Блумфільд, Кумар Дж. Нат. (2016). Домашня гігієна в країнах, що розвиваються. Попередження поширення інфекцій в домашніх умовах, (1), 5-173. [російська]

3. Володіна, О. (2012). Мікроб на полиці. Російська газета, (4), 21. Вилучено https://rg.ru/2012/01/12/microb.html [російська].

4. Наука та технології. (2017). Стафілокок у нашому домі : звідки беруться небезпечні штами. Вилучено 3 https://mir24.tv/news/16269020/stafilokokk-v-vashem-dome-otkuda-berutsya-opasnye-shtammy [російська].

5. Смірнова, У (2019). Де живуть мікроби : 10 найбрудніших місць у вашому домі. Вилучено 3 https://realty.rbc.ru/news/5d0fdf449a79470469d80661 [російська].

6. Супрун, У (2019). Ворог у вашій оселі. Шість місць, де нас очікують небезпечні бактерії. Вилучено 3 https://nv.ua/ukr/opinion/pribirannya-kvartir-ulyana-suprun-rozpovila-de-zhivut-bakteriji-50055551.html

\section{Хомякова Вероніка Сергіївна}

Харківський національний медичний університет, Украӥна

Мкртчян Аміна Аліксанівна, здобувач вищої освіти педіатричного факультету Харківський національний медичний університет, Украйна

Науковий керівник: Древаль Мар'яна Василівна, асистент кафедри гігієни та екології №1

Харківський національний медичний університет, Украӥна

\section{ВПЛИВ КАРАНТИНУ НА ЗМІНУ БІОЛОГІЧНОГО РИТМУ СТУДЕНТІВ}

Актуальність теми: Біологічний ритм відіграє важливе значення в житті кожної людини. Час коли ми прокидаємося i лягаємо спати, скільки разів на день харчуємося,впливає на наше самопочуття впродовж дня. Люди забувають, що наш біоритм залежить від способу життя. Ми взаємодіємо з навколишнім середовищем і наш організм пристосовується до нього [1]. Для студентів режим дня має велике значення, так як їм потрібно бути уважними і сконцентрованими. 3 настанням карантину студенти почали сидіти вдома, мало рухатись, менше перебувати на свіжому повітрі та невчасно і нераціонально харчуватись. Нові умови існування призвели до зміни їх звичного ритму життя.

Мета: Визначити як вплинув карантин на зміну біологічного ритму студентів та зрозуміти його важливість.

Хід роботи: Ми провели опитування серед 30 студентів 3 них: 25 дівчат і 5 хлопців . Для нього нами було розроблено 9 питань. Першим питанням було «Чи змінився ваш режим дня під час карантину?» — 7 (23\%) відповіло ні, а 23 (77\%) так.

Потім ми спитали «О котрій годині ви лягали спати до карантину ?» i «О котрій годині ви лягаєте спати зараз?». Студенти відповіли на ці два питання неоднозначно. У багатьох опитуваних час в який вони лягали спати до карантину і лягають зараз, суттєво змінився.

Наступним питанням було « Чи вплинув карантин на якість вашого сну?» 14 (48\%) відповіло «так, я почав висипатись», 8 (26\%) «ні я погано сплю», а для 8 (26\%) «карантин ніяк не вплинув».

На питання «Чи активно ви проводите свій вільний час?» тільки 10\% відповіло що «так»,а всі інші — «ні. Особливу увагу потрібно звернути на запитання про гаджети - 
90\% опитуваних, більшість свого часу через карантин почали приділяти гаджетам. На питання «Чи змінився ваш час прийому їжі за період карантину» 22 (73\%) відповіло що «так», а $8(27 \%)$ «ні».

«Скільки разів на день ви приймали їжу до карантину і скільки разів на день ви приймаєте їжу зараз?» до карантину 2-3 рази на день приймало їжу - 40\% , а 3-5 рази $60 \%$.

На сьогоднішній день ці показники дещо змінились, вже $87 \%$ опитуваних відповіли ,що стали їсти на 3 рази більше , а от 13\% не змінили своїх відповідей.

На останнє питання « Чи помічали ви у себе депресивний стан за цей період?» 17 (57\%) студентів відповіли - «так», а 13 (43\%) - «ні». Ми бачимо, що зміна звичного ритму життя приводить до емоційного напруження , а як наслідок - депресії.

Висновок: Ми можемо зробити висновок, що карантин негативно впливу на біоритм студентів, так як вони знаходяться в постійному стрессі через зміну звичних умов життя. Через дефіцит спілкування вони багато часу приділяють гаджетам, не звертаючи уваги на сон. За даними опитування ми бачимо зміну біологічного ритму у студентів за такими показниками як: переміна сну,порушення харчування,малорухливість, депресія. Практичне значення нашого дослідження полягає в тому, щоб донести до студентів важливість дотримання добового ритму. Якщо ігнорувати різку зміну біологічного ритму, можуть виникнути порушення функцій деяких органів,поява депресії,ожиріння.

\section{Список використаних джерел:}

1. Біологічні ритми i здоров'я людини [Електронний ресурс]. - Вилучено з: https://www.bsmu.edu.ua/blog/7026-biologichni-ritmi-i-zdorovya-lyudini/

Немеш Василь Іванович, студент 3 курсу Медичного факультету ДВНЗ "Ужсгородський національний університет", Украйна

\section{ВПЛИВ ТРАНС-ІЗОМЕРІВ ЖИРНИХ КИСЛОТ НА ОРГАНІЗМ ЛЮДИНИ}

Вступ. Останнім часом інтенсивно вивчається небезпечність впливу транс-ізомерів жирних кислот на організм людини, шляхи метаболізму, умови їхнього утворення та вміст в різних продуктах. Це пов'язано з тим, що вони можуть міститись у будь-якому продукті, де $\epsilon$ хоч крапля рослинного жиру - печиві чи цукерках, сметані чи твердому сирі, якщо молочний жир у них замінили на рослинний. Проблема впливу просторової так званої геометричної ізомеризації жирних кислот їхньої токсичності та антиаліментарного впливу на здоров'я людини стала активно вивчатися на початку 1970-х років, однак найбільш інтенсивний період її вивчення почався в 1990-х-2005 роках [1]. Розвиток багатьох хвороб цивілізації (IXC, АC, ЦД II типу) пов'язують із вживанням транс-ізомерів жирних кислот і включенням їх в склад біомембран, в результаті чого порушується їх функція. Але остаточних i зрозумілих даних відносно їх біомолекулярних механізмів впливу на різноманітні біологічні структури організму людини немає $[1,2]$.

Мета. Узагальнити відомості про молекулярні механізми впливу трансжирів на організм людини та їх роль у виникненні патології.

Матеріали та методи. Використано бібліосемантичний метод та контент-аналіз літератури відносно питань метаболізму транс-ізомерів жирних кислот в організмі людини, особливостей їх впливу на ліпідний обмін та порушень організму в цілому. Також 
проведено оцінювання різних харчових продуктів на вміст у них трансжирів, який зазначений на упаковці, у взаємозв'язку з ціновою категорією.

Результати. Ненасичені жири - це жири або жирні кислоти (ЖК), в яких є принаймні один подвійний зв'язок у ланцюзі жирної кислоти. У насичених жирах, у яких немає подвійних зв'язків, міститься максимальна кількість воднів приєднаних до атомів карбону. У клітинному метаболізмі, молекули ненасичених жирів містять менше потенціальної енергії (тобто, менше калорій), ніж еквівалентна кількість насичених жирів. Чим більша ступінь ненасиченості жирної кислоти (тобто, чим більше подвійних зв'язків у жирних кислотах) тим більш вразлива молекула до пероксидного окислення (згіркнення) $[2,6]$.

Транс-ізомери жирних кислот є одним з видів жирних кислот, для яких характерне розміщення атомів водню по різні сторони від вуглецевого скелета, так звана трансконфігурація, які для організму людини є ксенобіотиками, так як нормальні ЖК мають цисконфігурацію. Аналіз літературних джерел показав, що трансжирні кислоти за рахунок своєї специфічної конфігурації, радикально змінюють свої фізико-хімічні властивості. У транс-ізомерах жирних кислот атоми водню, пов'язані 3 двома атомами вуглецю, які утворюють подвійний зв'язок, розташовані на протилежних сторонах вуглецевого ланцюга. На відміну від більш типової цис-ізомерної конфігурації, кут подвійного зв'язку в трансжирних кислотах менший і становить $120^{\circ}$, а ацильний ланцюг більш лінійним, в результаті чого утворюється більш жорстка і пряма молекула з високою температурою плавлення, яка викликає жорстку упаковку молекул у мембранах. У цис-конфігурації атоми водню знаходяться на одній стороні вуглецевого ланцюга, кут подвійного зв'язку становить $123^{\circ}$, що призводить до "перегину" і сприяє закручуванню в ацильному ланцюзі і робить молекулу більш гнучкою і динамічною [3, 7].

Вуглеводневий ланцюг ЖК може утворювати вигини, так звані «кінки», дуже легко і швидко такі кінки утворюються цис-ізомерами ННЖК, тому поліненасичені ЖК можуть мати декілька кінків. По цій причині молекули цих кислот займають більший об'єм, а при формуванні кристалів упаковуються в них не так щільно, як транс-ізомери. Формуванню аномальних кінків сприяє перехід транс-конфігурації в гош-конфігурацію - це забезпечує перехід твердої форми в рідку і навпаки, тим самим приймаючи різні геометричні форми, змінюючи при цьому нормальні властивості мембран, причому їх формування може відбуватися вздовж всього вуглеводневого ланцюга, включаючи і насичені ділянки $[4,6]$. Тому поступове формування вздовж ланцюга кінків можна уявити собі як їх рух. Іншими словами, кінки можуть здійснювати внутрішньомембранний транспорт багатьох молекул. Таким чином, можна судити, що просторова структура трансжирних кислот знаходиться між насиченими жирними кислотами і цис-ненасиченими жирними кислотами. Тому кількість, геометрія та положення подвійних зв'язків у жирних кислотах впливають на їхнє всмоктування, метаболізацію, утилізацію, а також взаємодію 3 іншими субстратами в організмі людини.

Транс-жири - штучно створена субстанція, яка утворюється в ході модифікування рослинної олії. В умовах цієї реакції паралельно проходять такі основні процеси:

- перекручування молекул - перетворення цис-зв'язків у транс-зв'язки (геометрична ізомеризація);

- м міграція подвійного зв’язку в інше місце (позиційна ізомеризація);

- кінцевий продукт - в багатостадійному процесі очищення - саломас, в якому трансжирів більше як 50\%. Повторна модифікація дає ще більший вихід транс - ізомерів $[8,11]$.

Трансжири володіють спотвореною молекулярною структурою, яка невластива природнім сполукам. При надходженні їх із їжею вони включаються в нормальний метаболізм ліпідів. Вони розщеплюються у тонкому кишечнику і всмоктуються у вигляді 
гліцеролу і транс - ізомерних жирних кислот (близько 40\%). 3 - 10\% триацилгліцеролів всмоктуються без змін структури, інші ліпіди - у вигляді моногліцеролів. При цьому трансжирні кислоти, як і звичайні цис- 3 ланцюгом менше С10 проникають у капіляри портальної вени, і надходять безпосередньо в печінку. Жирні кислоти з більшою довжиною вуглецевого ланцюга надходять у лімфатичні капіляри у складі триацилгліцеролів, вбудовуються в хіломікрони і надходять у кров із лімфою через лімфатичні судини, а потім у печінку. Ліпіди транспортуються в інші органи і тканини в складі розчинних у воді ліпопротеїнових комплексів: зі стінки кишечнику - у вигляді хіломікронів, а з печінки у вигляді ліпопротеїнів різної щільності до органів і тканин. I на кожному з цих етапів транс-ізомери вносять свої корективи в їхню структуру і тим самим частково або повністю міняючи їх специфічні функції.

При включенні їх в структуру біологічних мембран, вони порушують всі статичні та динамічні їі властивості:

1) знаходячись у складі фосфоліпідів клітинних мембран (фосфатидилхолін, фосфатидилетаноламін, фосфатидилсерин, фосфатидилінозитол, сфінгомієлін та ін.), вони впливають на роботу білкових молекул, які пронизують мембрани, що призводить до порушення проникності, зміну електричного заряду по обидва боки від бімембранита та передачі сигналів роботи більшості молекул в нашому організмі (напр. взаємодія гормонів та рецепторів, а також, що є не менш важливим робота рецепторів на мембранах ядер клітин, модулюючих експресію генів);

2) фосфоліпіди служать матеріалом для синтезу регуляторних молекул імунної системи,

наявність в них жирних кислот в транс-конфігурації призводить до порушення біохімії захисно-запальних процесів;

3) транс - ізомери жирних кислот інгібують активність мембранно-асоційованих ферментів, таких як $\mathrm{Na}+$ / K + АТФаза і аденілатциклаза, ацил-СоА-десатурази, сукцинатцитохром С-редуктази, Фо-АТФ-ази і знижують щільність бета-адренергічних рецепторів у плазматичній мембрані будь-якої тканини, що може зумовлювати енергетичний голод в самій клітині і порушувати іiі роботу $[1,4]$.

Трансжири беруть участь у етіології різних метаболічних і функціональних розладів. Найбільший значущий вплив вони мають на розвиток дисліпідемії. Трансжирні кислоти збільшують ЛПНЩ за рахунок порушення взаємодії з рецепторами. Зменшують вміст ЛПВЩ через інгібування лецитин-холестерин-ацилтрансферази, яка естерифікує вільний холестерин у ЛПВЩ шляхом перенесення ацильної групи з фосфатидилхоліну (лецитин!), в результаті чого ефіри ХС переміщаються в ядро ЛП і звільняється місце для надходження нових порцій ХС. Виявлена зміна позиційної специфічності фосфатидилхоліну, коли в якості субстрату використовують трансжирні кислоти. Це може викликати інгібування ферменту і може дозволити утворення більш насичених ефірів холестерину, які $є$ більш атерогенними внаслідок їх підвищеного відкладення і зниження кліренсу з тканин. Таким чином, збільшення співвідношення холестерину ЛПНЩ до холестерину ЛПВЩ під впливом ТІЖК є приблизно вдвічі більшим, ніж у цис - насичених жирних кислот, тому їх називають ще гіперхолестериновими агентами [7].

Також не менш цікавий факт транс-ізомери мають вплив на ліпопротеїн (а), рівень цього макромолекулярного комплексу знаходить під генетичним контролем і суттєво не змінюється у нормі, фізіологічна роль його невідома i $\epsilon$ перспективою подальших досліджень у цій галузі. При вживанні ТІЖК рівень цього ліпопротеїну зростає, який у свою чергу є незалежним фактором IXC, атеросклерозу, тромбозу та інсультів.

Через вплив ТІЖК на метаболізм гамма-ліноленової та арахідонової кислоти, їх прийом може впливати на утворення простагландинів та інших ейкозаноїдів. У людей 3 наявною ендотеліальною дисфункцією ТІЖК модулюють реакцію моноцитів і макрофагів 
крові, внаслідок чого підвищуються рівні запальних маркерів: інтерлейкіну- 6, ФНП- $\alpha, \mathrm{C}-$ реактивного протеїну, Е-селектина, «липких» клітинних молекул, і як наслідок виникнення хронічних запальних процесів, метаболічного синдрому, дегенеративних хвороб [10].

Відносно впливу на вуглеводневий обмін $є$ спірним питанням. Велика кількість трансізомерів в раціоні сприяє розвитку інсулінорезистентності (за рахунок зменшенням чутливості інсулінових рецепторів - через зміну активності та структури фосфатидилінозитол-3-кінази і інсуліноподібного фактору росту), як фактор виникнення ЦД II типу [11].

Транс-жири змінюють функцію мембран життєво важливих клітинних структур, зокрема клітин головного мозку і нервових клітин. Вбудовуючись в нервові клітини головного мозку - сфінгомієліну та цереброзидів, вони витісняють з мембран вкрай важливі омега-3 та омега-6 жирні кислоти. Мембрани нервових клітин стають жорсткими, інертними, не можуть адекватно сприймати сигнали. Відповідно, вони гальмують роботу головного мозку, що найбільш згубно позначається на здоров'ї дітей і літніх людей. Було доведено, що регулярне споживання гідрогенізованих жирів загрожує розвитком хвороби Альцгеймера - ТІЖК сприяли утворенню та відкладенню специфічних «протеїнових бляшок» - $\beta$-амілоїду [6].

Надмірне споживання трансжирів порушує нормальний сперматогенез, сприяє утворенню аномальних сперматозоїдів або зниженню їх життєздатності - i як наслідок погіршення якості сперми. Також вони можуть порушувати склад передміхурового секрету в результаті чого можливе безпліддя [5].

Також нами було проведена оцінка складу деяких можливих потенційно небезпечних харчових продуктів, на вміст гідрогенізованих жирів. Було виявлено що практично всі продукти харчування, які ми оцінювали, містили транс-ізомери ЖК. I наявність їх тісно корелювала 3 ціною продукта, тобто чим продукт дорожчий тим більша ймовірність того, що його нема. Вміст ТЖ не вказується на упаковці, тому важко говорити про їх кількість.

Цікавим виявився той факт, що дуже рідко на упаковці зустрічається термін гідрогенізований жир. Тому виробники придумали цікаві моменти заміни цього слова:

Висновки. Таким чином, показано, що при вживанні трансжирів виникають різноманітні метаболічні порушення на молекулярному та субклітинному рівні, які негативно впливають на функцію практично всіх типів клітин і тканин, що сприяє розвитку патології або погіршує уже наявної. Узагальнюючи негативний багатогранний вклад трансізомерів жирних кислот в нормальні біологічні процеси, можна сказати, що потрібно вести контроль якості харчових продуктів та кількості ТІЖК в них. Враховуючи все вище представлене, потрібно контролювати свій раціон харчування, вести здоровий спосіб життя та бути педантичним відносно складу харчових продуктів.

\section{Список використаних джерел:}

1. Андреева Е.В., Химия и жизнь. Л. - 1967, (150-159с.) 189с.

2. Гонський Я.І., Максимчук Т. П., Біохімія людини. Тернопіль. Укрмедкнига 2002.

3. Довідник / За ред. Г.І. Столмакової, І.О. Мартинюка. - Львів: Світ, 1991. 2. Б.Н. Тютюнников «Біологія», Москва «Колос» 2008.

4. ДСТУ 4445:2005 Спреди та суміші жирові.

5. Евстигнеева Р.П., Е.Н. Звонкова «Біологія ліпідів», Москва, 2008.

6. Зайцев С.С. Вміст транс`ізомерів у вершковому маслі та його замінниках/ С.С. Зайцев, Л.I. Тищенко // Тези доповідей Міжнародної науково практичної конференції. -К., 2004.

7. Смоляр В.І. Концепція ідеального жирового харчування / В.І. Смоляр // Проблеми харчування. -2006. -№4. -C. 5-13.

8. Тютюнників Б.М. Хімія жирів. - М: Колос - 1992. - С. 102-118.

9. Ушакова В.Н. Стабильность липидов пищевых продуктов / В.Н. Ушакова -М.: Агропромиздат, -1988. -152 с.

10. Вилучено з http://dspace.nuft.edu.ua/jspui/bitstream/123456789/8418/1/79\%2 0\%20\% D0\%86V\%2 0\%20378-380.pdf

11. Вилучено з https://life.pra vda.com.ua/health/2012/03/12/98230/ 
Якушев Сгор Дмитрович, студент

Харківський начіональний медччний університет, Украӥна

Кікош Ксенія Юріївна, студентка

Харківський національний медичний університет, Украӥна

Науковий керівник: Овчаренко Ірина Анатоліївна, ас. кафедри фтизіатрії та пульмонології

Харківський національний медччний університет, Украӥна

\section{ДОЦІЛЬНІСТЬ ВИКОРИСТАННЯ БЦЖ В УКАЇНІ}

Вступ. Вакцинація БЦЖ завоювала визнання у багатьох країнах: вона обов'язкова в 64 країнах світу, офіційна рекомендована в 118. Це щеплення проведенно приблизно 2 млрд. людей різного віку і залишається основною формою профілактики туберкульозу в більшості країн, попереджаючи розвиток важких форм захворювання, пов'язаних 3 гематогенним поширенням мікобактерій. Імунізація БЦЖ знижує смертність від туберкульозу у дітей на $75-80 \%$.

Мета. Аналіз доцільності вакцинації БЦЖ, в залежності від показника тягаря хвороби на туберкульоз у різних країнах світу.

Матеріали та методи. Аналіз рекомендації Всесвітньої Організації Охорони Здоров'я від 23 лютого 2018 року щодо БЦЖ вакцини.

Результати та обговорення. M.tuberculosis вбиває і калічить більше дорослих осіб у віці від 15 до 59 років, ніж будь-яка інша хвороба в світі. У країнах, що розвиваються жінок дітородного віку помирає від ТБ більше, ніж від будь-яких інших причин, безпосередньо пов'язаних з вагітністю і пологами. Захворюваність ТБ зростає, особливо в найбідніших країнах і країнах, де широко поширений імунодефіцит, викликаний ВІЛ-інфекцією.

Згідно статистики, найвищий рівень оцінюваної захворюваності з розрахунку на 100 тис. населення був в 2015 р в Африканському регіоні - 275 (239-314) і країнах ПівденноСхідної Азії - 246, а самий низький - в країнах Америки - 27.

В результаті зниження значень цього показника в 2012-2013 pp. в групу 57 країн із середньою захворюваністю 25-99 на 100 тис. перейшли Україна (91), Казахстан (89) і Узбекістан (79). В інших 62 країнах світу захворюваність на туберкульоз не перевищує 25 на 100 тис. Населення, серед них 34 країни Європейського регіону ВООЗ, наприклад Великобританія (10), Німеччина $(8,1)$, Італія $(5,8)$, а також такі країни, як Японія (17) і США $(3,2)$.

У країнах з високим тягарем хвороби по туберкульозу, зокрема Україні, усі діти грудного віку повинні отримати одну дозу вакцини БЦЖ якомога раніше після народження. У підтвердження цього свідчить статистика, а саме: кількість дітей до 1 року в Україні, яким була проведена БЦЖ у 2018 складає 302457 осіб, що відповідає 90,1\% усіх дітей до 1 року, надоджених в Україні в цей час. Оскільки гострі побічні прояви при вакцинації БЦЖ зустрічаються вкрай рідко навіть серед ВІЛ-позитивних немовлят без клінічних ознак, всі здорові новонароджені повинні бути вакциновані БЦЖ. Однак, країни з низьким тягарем хвороби (США, Канада, Бельгія, Данія, Італія, Іспанія та ін.) де він становить близько 10,0 на 100000 населення, вакцинують тільки осіб, що входять до групи ризику, в тому числі живуть в несприятливих соціально-побутових умовах і вихідців 3 країн, де багато випадків захворювання на туберкульоз. У цих країнах вакцинацію БЦЖ в значній мірі замінили активне виявлення випадків захворювання і лікування на ранній стадії розвитку захворювання.

В Україні для того, щоб перейти від загальної вакцинації БЦЖ до селективної, повинна існувати ефективна система повідомлень на додаток до певних критеріїв: 
середньорічний показник нотифікації про випадки легеневого туберкульозу з позитивним мазком мокротиння нижче 5 на 100 000; або середньорічний показник нотифікації про туберкульозному менінгіті серед дітей у віці до п'яти років нижче 1 на 10 мільйонів населення протягом попередніх п'яти років; або середньорічний ризик зараження туберкульозом нижче $0,1 \%$.

Висновок. Стає абсолютно ясно, що невдачі в боротьбі з туберкульозом є прямим наслідком нерівності в розподілі матеріальних цінностей і надання медичної допомоги як всередині країн, так і між ними. Боротьба з туберкульозом $\epsilon$, в кінцевому рахунку, проблемою справедливості і прав людини. Розробка ефективних, безпечних і прийнятних в економічному відношенні вакцин проти туберкульозу повинна залишатися глобальним пріоритетом і в цій якості користуватися щедрою технічної та фінансової підтримки з боку міжнародного співтовариства.

\section{Список використаних джерел:}

1. Аксьонова В.А., Леві Д.Т., Фоніна Є.В. та ін. Вакцинопрофілактика туберкульозу: значення і проблеми // Пробл. туберкульозу та хвороб легенів. -2009. - №1. - С.10-16.

2. Аксьонова В.А., Мушкин А.Ю., Коваленко К.М. та ін. БЦЖ-остіти у дітей: епідеміологічні показники деяких регіонів Росії // Пробл. туберкульозу та хвороб легенів. - 2007. - №1. - С.9-12.

3. Афоніна Л.Ю., Воронін Е.Е., Рахманова А.Г. та ін. Диспансерне спостереження, догляд і лікування дітей, народжених ВІЛ-інфікованими жінками, і дітей з ВІЛ-інфекцією: Короткий посібник для фахівців центрів з профілактики та боротьби зі СНІДом. - М., 2006. -108с.

4. Баришнікова Л. А. Туберкульоз у дітей різного віку: вакцинація, хіміопрофілактика, особливості виявлення, клінічного перебігу // Пробл. туберкульозу та хвороб легенів. - 2009. - №6. - С. 16-19.

5. Батиров Ф.А., Киселевич О.К., Шамуратова Л.Ф. та ін. Проблеми туберкульозу у дітей, народжених від матерів, хворих на ВІЛ-інфекцією // Туберкульоз і хвороби легенів. - 2010. - №1 . - С.54-58.

Лещук Ірина Вололимирівна, лікар-інтерн Харківський національний медичний університет, Украйна

Науковий керівник: Гончарова Н.М., д. мед. наук, професор кафедри хірургії №2 Харківський начіональний медичний університет, Украӥна

\section{ЗАЛЕЖНІСТЬ ПІСЛЯОПЕРАЦЙННИ ГОРМОНАЛЬНИХ УСКЛАДНЕНЬ ВІД ОБ'ЄМУ ОПЕРАТИВНОГО ВТРУЧАННЯ НА ЩИТОПОДІБНІЙ ЗАЛОЗІ ТА МЕТОДИ ЇХ КОРЕКЦІї}

Вступ та актуальність. Близько половини захворювань ендокринної системи складає патологія щитоподібної залози (ЩЗ), що обумовлено екзогенними факторами. Захворювання Щ3 діагностують більш ніж у 40\% дорослих, у приблизно $20 \%$ дітей та у 80\% людей похилого віку [2].

Щ3 продукує гормони - тироксин (Т4) та трийодтиронін (Т3), які регулюють усі види обміну речовин організму людини, впливають на терморегуляцію та процеси окиснення. Тиреокальцитонін має виражену гіпокальціємічну дію.

Оперативне лікування захворювань ЩЗ передбачає повне або часткове видалення тканин залози. Показаннями до оперативного лікування $є$ різні види раку, вузли великих розмірів, що призводять до здавлювання органів шиї чи є причиною косметичного дефекту передньої поверхні шиї, гормонпродукуючий вузол, що призводить до стану тиреотоксикозу, мультинодулярний зоб, хвороба Грейвса, особливо за наявності 
екзофтальму. Виконуються наступні види операцій: тиреоїдектомія (лікування багатовузлового чи дифузного токсичного зобу), субтотальна резекція, за якої лишають невеликі ділянки залози (деякі випадки дифузного токсичного зобу чи багатовузлового зобу, гіпертрофічної форми аутоімунного тиреоїдиту), гемітиреоїдоектомія з видаленням перешийка, гемітиреоїдектомія, тобто видалення однієї частки залози (фолікулярна аденома, токсичний вузловий зоб), резекція перешийка ЩЗ (якщо вузловий зоб знаходиться в перешийку). Постопераційними ускладненнями, які чинять відчутний вплив на подальше життя пацієнта, є гіпотиреоїдизм, пошкодження зворотнього гортанного нерву, постопераційний гіпопаратиреоз.

Постопераційний гіпотиреоз $є$ прямим наслідком скорочення кількості гормонсекретуючої тканини залози, характеризується загальною слабкістю, відчуттям стомленості, апатичністю, сонливістю, загальною загальмованістю. Шкіра хворих стає сухою та набряклою, покривається зморшками, спостерігається випадіння волосся, болі в кінцівках, зниження статевої функції.

Післяопераційний гіпопаратиреоз розвивається внаслідок видалення паратиреоїдних залоз (ПТЗ) в ході операції на ЩЗ, крововиливів в них чи фіброзних процесів у залозах у післяопераційному періоді. Цей стан являє собою післяопераційне зниження рівня кальцію сироватки крові нижче 1,9 ммоль/л за наявності симптомів (напади тонічних судом, частіше - м'язів обличчя, верхніх кінцівок із залученням симетричних груп м'язів; може виникати ларингоспазм з асфіксією, симптоми Хвостека та Трусо) або без них або післяопераційний рівень сироваткового кальцію 1,0-2,1 ммоль/л 3 нейро-м'язовими симптомами через 2 дні після операції.

Виділяють транзиторний та стійкий гіпопаратиреоз. Перший характеризується відновленням фосфорно-кальцієвого обміну протягом 12 місяців після перенесеної операції [1]. Механізм даного стану обумовлений пошкодженням в ході операції судин, що кровопостачають Щ3. Кровопостачання ПТЗ наполовину забезпечується власними судинами цих залоз, наполовину здійснюється з судин ЩЗ. Якщо власні судини ПТЗ у ході операції не були пошкодженими, то через певний проміжок часу, необхідний для відновлення, ці судини зможуть забезпечити повноцінне функціонування ПТЗ. Стійкий гіпопаратиреоз проявляється зниженням рівня кальцію сироватки крові та ператгормону протягом більш ніж 12 міс., що відбувається через повне припинення кровопостачання ПТЗ або їх видалення в ході операції.

Мета роботи: дослідити залежність між видом оперативного втручання на ЩЗ та рівнем гормональної дисфункції після операції, визначити методи іiї корекції.

Матеріали та методи. Проаналізовано дані історій хвороби 155 хворих за 2016-2019 роки, які були прооперовані з приводу патології ЩЗ та лікувалися у хірургічному відділенні КНП «Обласна клінічна лікарня» Харківської обласної ради. Статевий розподіл пацієнтів: 53 (34,2\%) чоловіка та 102 (65,8\%) жінки. Середній вік пацієнтів становив 44,5 років. Усім пацієнтам проведені загальні дослідження, біохімічний аналіз крові 3 визначенням показників ТТГ, вільного Т4, кальцію сироватки крові, гормону ПТЗ, УЗД або еластографія ЩЗ, пацієнтам з підозрою на наявність злоякісного процесу була проведена тонкоголкова аспіраційна біопсія за показаннями та інтраопераційне експрес-цитологічне дослідження. Пацієнти були поділені на групи за обсягом оперативного втручання. До першої групи увійшли пацієнти, яким за показаннями було виконано тотальну або субтотальну резекцію щитоподібної залози, сюди ж віднесені пацієнти з відповідним обсягом операції, рішення щодо якого було прийнято в ході операції після проведення інтраопераційної цитобіопсії та підтвердження наявності злоякісного новоутворення - 98 (63,2\%). Показання до операції у даній групі були наступними: доброякісний вузол великих розмірів - 10 (9,8\%), багатовузловий зоб - 17 (17,3\%), фолікулярна пухлина у одній частці з подальшим підтвердженням злоякісного характеру новоутворення - 7 (7,4\%), рак Щ3 - 55 (56,1\%), 
дифузний токсичний зоб - 9 (9,2\%). 3 них гіпертиреоз перед операцією діагностовано у 16 $(16,3 \%)$ пацієнтів даної групи, гіпотиреоз - у 5 (фолікулярний рак). Пацієнти 3 гіпертиреозом були прооперовані по досягненні нормальних показників тиреоїдних гормонів після проведення гормонсупресивної терапії для попередження тиреотоксичної кризи після операції. До другої групи увійшли пацієнти, яким було виконано гемітиреоїдектомію ЩЗ за показаннями - усього 57 (36,8\%) пацієнтів, з яких доброякісний одиничний вузол розташований у межах однієї частки залози мав 51 (89,5\%) пацієнт, фолікулярну аденому, доброякісний характер якої був підтверджений у ході інтраопераційного цитобіологічного дослідження - 6 (10,5\%). У всіх пацієнтів даної групи відзначався нормальний рівень тиреоїдних гормонів до операції.

Результати та їх обговорення. Серед пацієнтів першої групи гіпопаратиреоз протягом перших двох днів був виявлений у 35 хворих (35,7\%), з них у 33 пацієнтів цей стан мав транзиторний характер. 3 другої групи транзиторний гіпопаратиреоз був виявлений у 3 пацієнтів (5,3\%). Терапія хронічного гіпопартиреозу провидиться під моніторингом показників кальцію сироватки крові. За показників нижче 2 ммоль/л призначають пероральний прийом препаратів кальцію (кальцій карбонату або кальцію цитрату) разом $з$ препаратами вітаміну Д. Подальше ведення таких хворих здійснюється спільно хірургом та ендокринологом. Дози препаратів коригуються залежно від показників аналізів. Протягом періоду підбору дозування контроль показників кальцію, фосфатів крові та креатиніну проводять 1 раз на місяць, потім - двічі на рік. Ускладненням даної терапії $є$ розвиток нефролітіазу, нефрокальцинозу або хронічного захворювання нирок, що спричинено відсутністю впливу гормонів ПТЗ на ниркові канальці, причому вміст кальцію сироватки може знаходитися на верхній межі норми цільових показників $(2,1-2,4$ ммоль/л) [3]. У зв'язку з цим є доцільним додати до планового моніторингу стану пацієнтів загальний аналіз сечі. Замісна гормональна терапія наразі не набула широкого застосування через низьку біодоступність та незначний період циркуляції гормону в крові [1]. Ризик розвитку хронічного гіпопаратиреозу тісно пов'язаний з кількістю тканини ПЩЗ, що лишилася після операції in situ: 16\% при збереженні 1-2 залоз, 6\% при 3-х залозах, 2,5\% при збереженні усіх 4 залоз [5].

Усім пацієнтам першої групи з перших днів після операції була призначена замісна гормональна терапія препаратами L-тироксину з метою корекції гіпотиреозу. Біохімічним маркером розвитку гіпотиреозу був показник ТТГ більший за 4,05 мОд/л. Брали до уваги наявність симптомів гіпотиреозу. Цільовими значеннями ТТГ були 0,4-4,0 мОд/л. В подальшому корекція доз відбувалася, спираючись на показники ТТГ, які досліджували кожні 2 місяці до визначення оптимальної дози L-тироксину, потім - кожні пів року разом з УЗД шиї. Негайне призначення замісної гормональної терапії тироксином пацієнтам, що перенесли гемітиреоїдектомію $є$ дискусійним питанням. Аргументами «за» $є$ попередження рецидиву зобу, зменшення ризику злоякісної конверсії та компенсація гіпотиреозу. За умови збереження певної кількості тканин Щ3 питання про необхідність призначення Lтироксину може бути вирішено, спираючись на дані дослідження ТТГ протягом кількох місяців після операції, оскільки за наявності контролю розвиток тривалого некомпенсованого гіпотиреозу маловірогідний. Підвищений рівень ТТГ та наявність симптомів свідчить про маніфестацію післяопераційного гіпотиреозу, що спостерігалося у 8 (14\%) пацієнтів другої групи, яким була призначена замісна терапія. 3 них 4 оперовані 3 приводу фолікулярної аденоми, 4 - 3 приводу вузлового зобу. Ще у 3 пацієнтів виявлено субклінічний гіпотиреоз. Хронічний гіпотиреоз розвинувся у 5 пацієнтів 3 числа вищезазначених. Пацієнтам з еутиреозом проводився ретельний моніторинг біохімічних показників на 1, 3, 6, 12 місяці за умови відсутності симптомів. Гіпотиреоз протягом 6 місяців після операції був виявлений у 10 пацієнтів (у 7 пацієнтів був безсимптомним). За наявності симптомів, замісна терапія призначалася негайно, у разі безсимптомного 
перебігу, коли ТТГ знаходиться в межах 5,5-6,9 мОд/л - протягом перших 6 місяців після операції, показаний подальший контроль показників ТТГ кожні пів року. За відсутності стабілізації гормонутворюючої функції або при виникненні симптомів гіпотиреозу призначалася замісна терапія. Якщо показник ТТГ менше 5,5 мОд/л - показаний контроль через 12 місяців та кожного року або за дебюту симптоматики [4].

Висновки. Стійкий постопераційний гіпопаратиреоз не $\epsilon$ розповсюдженим ускладненням оперативних втручань на ЩЗ. Так, у ході дослідження він був виявлений у $2 \%$ пацієнтів, що перенесли тиреоїдектомію, та не виявлений у пацієнтів другої групи. Проте пацієнти з даним станом мусять пожиттєво знаходитися на препаратах кальцію та вітаміну Д, регулярно проходячи обстеження, спрямовані на корекцію дози та виявлення можливих ускладнень терапії. Транзиторний гіпопаратиреоз був виявлений у 33,7\% пацієнтів першої групи та у 5,4\% пацієнтів другої групи. Даний стан потребував корекції для усунення проявів та наслідків гіпокальціємії, разом з тим - ретельного спостереження протягом першого року після операції, що дозволяє виявити транзиторний характер даного стану.

Щодо стану післяопераційного гіпотиреозу, замісну терапію було проведено усім пацієнтам з першої групи через високий ризик розвитку гіпотиреозу за відсутності тканин Щ3 як єдиного джерела продукції тироксину та трийодтироніну. Замісна терапія Lтироксином добре переноситься пацієнтами. Після операції обов'язковими є планові обстеження у хірурга та ендокринолога. 3 другої групи маніфестація гіпотиреозу після операції відбулася у 14\% пацієнтів, гіпотиреоз з субклінічним перебігом - у 5,3\% даної групи. Стійкий гіпотиреоз залишився у половини вищезазначених пацієнтів та у 5\% групи загалом. У 10\% даної групи гіпотиреоз був виявлений протягом 6 місяців післяопераційного спостереження, причому у 7\% він був безсимптомний. Тактика призначення замісної терапії для пацієнтів, що перенесли гемітиреоїдектомію спиралася на наявність клініки гіпотиреозу та показники біохімічного моніторингу.

\section{Список використаних джерел:}

1. Аюшеева А.В. Послеоперационный гипопаратиреоз, способы профилактики и коррекции / А. В. Аюшеева, Е. А. Ильичева, С. А. Лепехова // Бюллетень ВСНЦ СО РАМН. - 2013. - №1 (89). - С.160-164.

2. Вадзюк Ю.С. Оптимізація фармакологічного забезпечення хворих з патологією щитоподібної залози : дис... канд.. фарм. наук : 15.00.01 / Ю. С. Вадзюк. - Тернопіль, 2017. - 144 с.

3. Мокрышева Н.Г. Гипопаратиреоз: этиология, клиническая картина, современные методы диагностики и лечения / Н. Г. Мокрышева, А. К. Еремкина, Е. В. Ковалев // Альманах клинической медицины. - 2016. Апрель-май; 44 (4): 477-492. - С. 477-492.

4. Хрыщанович В.Я. Гипотиреоз поле гемитиреоидэктомии: частота встречаемости, факторы риска, лечение / В. Я. Хрыщанович, С. И. Третьяк, Е. В. Богомазова // Новости хирургии. - 2010. - №6; том 18. - С. 21-27.

5. Grodski S., Serpell J. Evidence for the role of perioperative PTH measurement after total thyroidectomy as a predictor of hypocalcemia // World Journal of Surgery. - 2008. - № 32(7). - P. 1367-1373. 


\section{Мареніч Ганна Геннадіївна}

Харківский національний медичний університет, Украӥна

Явтушенко Аліна Євгенівна, здобувач вищої освіти педіатричного факультету Харківский національний медичний університет, Украӥна

Науковий керівник: Древаль Мар’яна Василівна, асистент кафедри гігієни та екології №1 Харківский національний медичний університет, Украӥна

\section{МЕДИЧНІ ВІДХОДИ: ПРОБЛЕМИ ТА МЕТОДИ УТИЛІЗАЦІї}

Мета роботи: Привернути увагу до проблеми утилізації медичних відходів. Розкрити можливі наслідки нехтування санітарно-гігієнічних норм утилізації. Розглянути питання про утилізацію медичних масок, рукавичок соціумом, особливо під час пандемій.

На сьогоднішній день медицина є однією із стрімко розвиваючих галузей наукової та практичної діяльності. Вона допомагає оцінити нормальний та патологічний стани здоров'я, знайти та підібрати методи лікування, покращити якість життя.

Зараз у непростий в боротьбі з COVID-19 час медицина є важливим і єдиним метод боротьби з пандемією. Але попри всю значимість $є$ і свої недоліки. Рятуючи людські життя, медицина продукує велику кількість відходів, які згубно впливають на флору і фауну нашої планети.

Для обгрунтування та підкріплення матеріалу нашого дослідження доречно було спиратись на Наказ Міністерства Охорони Здоров’я України №325 «Про затвердження Державних санітарно-протиепідемічних правил і норм щодо поводження з медичними відходами» [1].

За наказом термін «медичні відходи» трактується як відходи, що утворюються в результаті медичного обслуговування в установах, які в установленому порядку отримали ліцензію на провадження господарської діяльності з медичної практики (крім підприємств по виробництву фармацевтичної продукції та медичних відходів, що утворюються в побуті) [1].

Існує велика кількість різноманітного сміття, класифікацію та види якого можна знайти у наказі МО3 №325. Саме нами було розглянуто медичні відходи класу «Б» та «В», які вважаються найнебезпечнішими, бо піддаються тільки хімічній дезінфекції, а це не може стовідсотково гарантувати екологічну безпеку та епідеміологічну захищеність.

Клас «Б» вважають небезпечними або ризикованими відходами, тобто потенційно інфікованими це - матеріали, інструменти та інші предмети забруднені різноманітними виділеннями такими як кров, гній та біологічні відходи з операційних, а саме органи, тканини, плацента тощо.

До класу «В» відносять надзвичайно небезпечні відходи - матеріали, що мали контакт iз небезпечними інфекційними хворими наприклад пацієнтами фтизіатричних лікарень.

Літературні джерела говорять, що в 1 г такого медичного сміття мешкає приблизно 200 - 300 млрд. різноманітних мікроорганізмів [2]. Ця інформація показує усю небезпеку та проблему утилізації медичних відходів небезпечних класів. Яка полягає у дезінфекції і подальшому зберіганні чи вивезенні у герметичних контейнерах та пакетах. Відсутність спеціальної обробки не дозволяє піддавати кремації або закопувати відходи у землю, так як це призведе до отруєння інфекціями, бактеріями та мікробами підземних вод, річок, флори та повітря.

Слід зазначити, що неправильно утилізоване сміття може піддати ризику здоров'я та життя всієї фауни, а нерозумно утилізовані голки та шприці приводять до набуття СНІДу або гепатиту мільйонами людей. 
На сьогоднішній день планету охопила пандемія COVID - 19, що змусила кожного 3 нас використовувати у своєму повсякденному житті медичні засоби власного захисту (МЗВ3). Вимушені міри поставили перед людством на всій планеті питання утилізації медичних масок, респіраторів та рукавичок в масовому масштабі. У мережі інтернету та ЗМІ з’явилось безлічь інформації, щодо користування та позбавлення від МЗВЗ.

Медики стверджують, що маски які не піддаються подальшій вторинній переробці, необхідно збирати у герметичні пакети та спалювати. 3 респіраторами дещо складніше, так як в них поєднується кілька матеріалів, тому для подальшої переробки їх необхідно розбирати - окремо пластик, фільтри тощо. Але важливо те, що матеріали які перебували в контакті з людьми під час захворювань повинні бути спаленими [3].

Нам стало цікаво чи дослухаються люди до порад спеціалістів, чи недбало ставляться до сучасних проблем. Тому було розроблене та проведене анонімне онлайн опитування «Утилізація медичних масок» серед студентів ХНМУ. Воно містило ряд питань, з яких ми дізнались, що більшість студентів - 64,7\% користуються одноразовими масками, 29,4\% саморобними (багаторазовими). 94,1\% використовують маски кожен день. Беручи до уваги питання «Як ви викидаєте маски?» опитування показало, що 52,9\% викидають їх до смітника у власному будинку, а 47,1\% не викидають взагалі або викидають на вулиці. Найцікавішим виявилось питання «Чи обробляєте ви маски перед тим як викинути?» на яке $100 \%$ студентів відповіли - ні. 3 урахуванням результату попереднього питання, стало прикро, бо 41,2\% студентів знають як правильно викидати маски, але не дотримуються правил, а 58,8\% відповіли, що не знали про це взагалі.

Ці результати говорять про недбале ставлення нашої молоді до навколишнього середовища, а також про інформаційний дефіцит людей у цьому питанні. На думку представників екологічних організацій, ситуація що склалася у світі не дозволяє людині бездумно та неправильно утилізувати медичні маски, бо це може спричинити новий спалах COVID-19.

Підбиваючи підсумки зробимо висновок про загальну ситуацію, яку можна вважати відносно благополучною. Але слід зазначити, що в нашій країні необхідно сформувати налагоджену систему утилізації різного виду медичних відходів, а також періодично інформувати населення, щодо знищення та знезаражування засобів власного захисту (медичних масок та рукавичок). Ці питання мають бути вирішені за короткий термін часу, оскільки це може стати першим етапом до неможливості забезпечення населення країни екологічною безпекою.

Опрацювавши інформаційні джерела та зробивши власні висновки, ми можемо запропонувати заходи, щодо покращення ситуації у питанні утилізації медичних відходів, тобто:

1. Створення попереднього плану скорочення використання і збору медичних відходів;

2. Мінімізування недбалого ставлення працівників і соціуму до утилізації відходів класу «Б» та «В»

3. Впровадження в навчальну практику студентів медичних вузів вивчення впливу найнебезпечніших класів відходів та інших шкідливих для екології забруднювачів.

\section{Список використаних джерел:}

1. Про затвердження Державних санітарно-протиепідемічних правил і норм щодо поводження з медичними відходами [Електронний ресурс]. - Режим доступу: https://zakon.rada.gov.ua/laws/show/z0959-15

2. Проблемні питання при поводженні з медичними відходами в україні [Електронний ресурс]. - Режим доступу:

https://eprints.oa.edu.ua/8117/1/ПРОБЛЕМНІ\%20ПИТАННЯ\%20ПРИ\%20ПОВОДЖЕННІ\%203\%20МЕДИ ЧНИМИ\%20ВІДХОДАМИ\%20В\%20УКРАЇНІ.pdf

3. Як правильно утилізувати використані маски [Електронний ресурс]. - Режим доступу: https://kolo.news/category/suspilstvo/19375 
Глущенко Ірина Ігорівна, здобувач вищої освіти I медичного факультету Харківський національний медичний університет, Украйна

Некрасова Наталя Михайлівна, здобувач вищої освіти I медичного факультету Харківський національний медичний університет, Украйна

Науковий керівник: Долженко М.О., доцент кафедри медицини невідкладних станів, анестезіології та інтенсивної терапії

Харківський національний медичний університет, Украӥна

\section{МЕТОДИ ДІАГНОСТИКИ ТЯЖКОЇ ІНТУБАЦІЇ ТРАХЕЇ У ПАЦІЕНТІВ 3 ОЖИРІННЯМ}

Проблема ожиріння є досить актуальною, адже набула масштабів епідемії. За даними ВОО3, у світі нараховується 1,9 млрд. людей, що мають надмірну вагу, з них 650 млн. страждають ожирінням. В Україні 58,4\% населення старше 18 років мають надмірну масу тіла. Для верифікації ожиріння використовують показник індексу маси тіла.

3 точки зору анестезіології, надмірна вага або ожиріння $є$ важливим фактором ризику у пацієнтів, і може призвести до виникнення ряду ускладнень. Близько $35 \%$ всіх випадків важкої інтубації припадає саме на категорію пацієнтів із ожирінням.

Поки що не існує єдиних підходів до передопераційного обстеження пацієнтів 3 цією проблемою.

Для визначення важкої інтубації трахеї важливе значення має візуалізація голосової щілини. Для цього використовують діагностичний тест Cormack-Lechane, який оцінюють за допомогою непрямої або прямої ларингоскопії. Тяжкість інтубації має чотири ступені. Візуалізація голосової щілини під час інтубації трахеї, що відповідає I-му і II-му ступеням, визначається як нескладна інтубація, а останні два ступені асоціюються з високим ризиком тяжкої інтубації трахеї. Тест Cormack-Lechane має бути зазначений у кожному протоколі анестезії, а при III або IV ступені тяжкості лікар-анестезіолог повинен зробити відмітку про визначений ступінь.

Також у світовій практиці важливе місце посідає шкала El-Ganzouri. Ця шкала поєднує 7 критеріїв, за якими визначають метод забезпечення прохідності дихальних шляхів. Дослідження доводять, що шкала має високу діагностичну цінність у відношенні проблеми прогнозування тяжкості дихальних шляхів у пацієнтів з ожирінням.

Отже, відмітимо, що важка інтубація у пацієнтів з ожирінням залишається значною проблемою в сучасній анестезіології та поки що не існує єдиних підходів до передопераційного обстеження пацієнтів 3 цією проблемою. Проте безвиняткова та своєчасна передопераційна оцінка дихальних шляхів пацієнтів 3 надмірною вагою та ожирінням дає необхідну інформацію та час для проведення більш повноцінної підготовки до анестезії. Однак, ця проблема потребує подальшого вивчення.

\section{Список використаних джерел:}

1. О.О.Буднюк, І.Л Басенко (2013) Тяжка інкубація трахеї, прогнозування і тактика лікаря-анестезіолога. Проблеми анестезіологї̈ та інтенсивної терапії. 1, 7-12.

2. Ф.С.Глумчер, Л.П. Чепкий, Л.В. Усенко, В.Ф.Москаленко та ін.(2010). Анестезіологія та інтенсивна терапія.Київ: ВСВ «Медицина».

3. А.А.Климов, А.А. Малахова, С.А. Камнев, В.В. Субботин (2018) Использование прогностической шкалы El-Ganzouri в оценке трудних дыхательных путей у пациентов с ожирением. Вестник анестезиологии и реаниматологии, 15(2), 38-44.

4. Antons Zakalkins, Sigita Kazune (2017). Prediction of Difficult Tracheal Videolaryngoscopic Intubation Using El-Ganzouri Risk Index. ACTA CHIRURGICA LATVIENSIS, (17/1), 18-22.

5. World Health Organization. Obesity. URL: https://is.gd/pQqQNz 
Савченко Дар'я Миколаївна, здобувач вищої освіти медичного факультету Вищий державний навчальний заклад Украйни «Буковинський державний медичний університет», Україна

Науковий керівник: Печеряга Світлана Володимирівна, кандидат медичних наук, асистент кафедри акушерства, гінекології та перинаталогії

Вищий державний навчальний заклад Украӥни «Буковинський державний медичний університет», Україна

\section{ПРОБЛЕМИ РЕПРОДУКТИВНОЇ ФУНКЦІї ЖІНОК}

Благополуччя кожної країни залежить від складу її населення та закономірності його розвитку, яке визначається здатністю до простого відтворення. Упродовж останніх десятиліть в Україні спостерігається стійка тенденція до скорочення чисельності населення, а це свідчить про погіршення здоров'я, передусім у жінок. Це носить загрозливий характер для майбутнього держави, що робить проблему репродуктивно здоров'я загальнонаціональною. До речі, відмічається стійке зростання загальної та гінекологічної захворюваності жінок в Україні. Кожна третя жінка в момент вступу в репродуктивний вік має прояви будь-якої екстрагенітальної патології. Основними проблемами у сфері репродуктивного здоров'я на сьогоднішній день є: низький рівень народжуваності на фоні зростання рівня безпліддя, мертвонароджуваності, спонтанних абортів, вроджених вад розвитку, материнської та дитячої смертності $[1,4]$.

Щоб з'ясувати основні причини низького рівня репродуктивного здоров'я жінок та визначити методи його запобігання, було проведено анкетування серед 200 дівчат віком від 15-23 років. Шляхом опитування було визначено початок статевого життя, засоби контрацепції, кількість статевих партнерів та отримано наступні результати, які надаються нижче (табл.1. та табл.2).

Таблиия 1

Характеристика початку статевого життя у дівчат

\begin{tabular}{|c|c|}
\hline Вік початку статевого життя & Кількість опитуваних у відсотках \\
\hline До 16 p. & $10 \%$ \\
\hline $317-18$ p. & $50 \%$ \\
\hline $319-20$ p. & $35 \%$ \\
\hline Після 20 p. & $5 \%$ \\
\hline
\end{tabular}

[авторська розробка]

Майже кожна третя дівчина мала статевий контакт більше ніж з одним статевим партнером.

Таблиия 2

Використання методів контрацепції

\begin{tabular}{|c|c|}
\hline Метод контрацепції & Відсоток використання серед опитуваних \\
\hline Презервативи & $50 \%$ \\
\hline КОК & $10 \%$ \\
\hline ВМК & $5 \%$ \\
\hline Ніякий з методів контрацепції & $25 \%$ \\
\hline Інші методи & $10 \%$ \\
\hline
\end{tabular}

[авторська розробка]

Аналізуючи результати опитування, ми бачимо, що значний відсоток дівчат взагалі не використовують методи контрацепції. В результаті чого майже $80 \%$ вагітностей 
та пологів $є$ незапланованими та небажаними. Це часто призводить до порушення отримання освіти та подальшого життя дівчини. На даний час більшість підлітків користуються контрацептивними засобами, але багатьом не вдається використовувати найефективніші методи або ж використовують їх неправильно, непослідовно. Це стає причиною небажаної вагітності. Навіть поінформовані підлітки можуть мати проблеми 3 доступом до контрацептивів [2].

Підлітки вважають, що вагітність неможлива при першому статевому контакті, при збільшенні частоти статевих актів з декількома партнерами одночасно. Вони впевнені у ефективності перервного статевого акту, підозріло ставлять до гормональних препаратів і використання презервативів. Несерйозне відношення підлітків також до інфекцій, які передаються статевим шляхом, адже вважають, що це їх не зачепить або в будь-якому випадку можна пройти лікування.

За останні десятиліття репродуктивний потенціал сучасних жінок має негативний характер, що проявляється в поширені шкідливих звичок, відхиленнях в психічному, фізичному та статевому розвитку, спостерігається збільшення тенденції до захворюваності на гінекологічні на венеричні захворювання, низький рівень статевого освітнього процесу та контрацептивного вибору.

Фактори, що впливають на репродуктивний стан здоров'я жінок можуть бути різноманітними. Найбільше значення мають злоякісні новоутворення або запальні захворювання статевої системи та молочних залоз. Важливу роль в стані репродуктивного життя відіграє також безплідність жінок, що в більшості випадків виникає через запалення статевих органів або штучного переривання вагітності, адже воно має вплив не тільки на фертильність, а також на наступну вагітність та її пологи. Це все в свою чергу призводить до демографічних втрат населення. Кожного року захворюваність від цих патологій має тенденцію до зростання. Стан репродуктивної системи має тісний зв'язок з соматичним та психічним здоров'ям, що є показником якості життя. Саме до порушень репродуктивних функцій призводять патологічні процеси у внутрішніх статевих органах. Відмічається тенденція до невиношування вагітності, що супроводжується мимовільним викиднем або передчасними пологами. Особливо небезпечними є інфекції, що передаються статевим шляхом, що стають причинами безплідності, онкогінекологічних патологій, невиношуванням вагітності, а також внутрішньоутробним інфікування плода $з$ наслідками і вадами розвитку. Найбільш поширені серед них - гонорея, хламідіоз, урогенітальний трихомоноз, бактеріальний вагіно3, генітальний герпес, уреоплазмоз, кандидоз, ВІЛ та інші. Ці всі фактори створюють реальну загрозу як для порушення становлення репродуктивної системи, так і можливості функціонування ії̈ в майбутньому $[3,5]$.

Висновки. Стан репродуктивного здоров'я залежить від раннього початку статевого життя, швидкості статевого дозрівання, зміни статевих партнерів, абортів, інфекцій, що передаються статевим шляхом та різних захворювань статевої системи. До заходів профілактики можна віднести: підвищення інформованості і освітнього рівня населення, формування контрацептивного вибору і культури репродуктивної поведінки, застосування технологій максимально безпечного аборту, а у випадку, коли жінка вирішує мати дітей, вони повинні мати доступ до послуг, які надають їй змогу мати належну вагітність, безпечні пологи та забезпечення здоров'я дитини.

\section{Список використаних джерел:}

1. Гойда Н. Г. Нормативно-правове регулювання діяльності служби планування сім'ї та збереження репродуктивного здоров'я / Н. Г. Гойда, О. Ю. Бісярін // Часопис. - 2012. - № 4 (90), VII/VIII. - С. 7-9.

2. Горбенко О.В. Аспекти прихильності сучасної молоді до контрацепції / О.В. Горбенко// Медико-соціальні проблеми сім'ї. - 2006. - Т.11, №3. - С. 116-118.

3. Дзісь Н.П. До питання порушення репродуктивної функції у жінок із гінекологічною патологією запального та незапального генезу / Н.П. Дзісь // Biomedical and biosocial anthropology. - 2014. - № 23. C. 239-243. 
4. Про затвердження Державної програми “Репродуктивне здоров’я націі” на період до 2015 року: постанова КМУ від 27.12.2006p. №1849 [Електронний ресурс]. - Режим доступу: http://www.rada.gov.ua.

5. Скурятіна Н. Г. Роль запальних захворювань геніталій у формуванні порушень репродуктивної функції жінок / Н. Г. Скурятіна, О. П. Гнатко // Медико-соц. пробл. сім'ї. - 2006. - № 2. - С. 160-163.

Кузьмак Мар'яна Василівна, студентка 5 курсу Медичного факультету ДВНЗ "Ужсгородський національний університет", Украйна

Науковий керівник: Ростока Лариса Михайлівна, доцент кафедри біохімії, фармакології та фізичних методів лікування з курсом аналітичної медицини Медичного факультету ДВНЗ "Ужгородський національний університет", Україна

\section{РОЛЬ ДЕЯКИХ БІОХІМІЧНИХ РЕАКЦІЙ В ОРГАНІЗМІ ЛЮДИНИ}

Вступ. Відомо, що для організму людини характерною особливістю $є$ наявність біохімічних реакцій. Вони відбуваються за допомогою спеціальних речовин-ферментів. $€$ велика різноманітність біохімічних реакцій, а також дуже велика кількість ферментів, які 3 кожним роком досліджуються все більше й більше. Можна вважати, що вони також деякою мірою забезпечують індивідуальність організму. Не так давно було доведено, що у нашому організмі є реакції, які проходять без участі ферментів, тобто не ферментативні реакції. Відомо, що ці реакції протікають дуже повільно, тому їхнє дослідження можливе лише при використанні високочутливих методів аналізу. Проте дослідження не ферментативних реакцій справді $\epsilon$ важливим, так як наш організм- жива система, всі елементи якої у постійній взаємодії, а тому необхідним елементом є його дослідження.

Мета роботи. Дати визначення не ферментативних реакцій і пояснити важливість їх дослідження, можливі перспективи.

Матеріали та методи. Використано метод логічного узагальнення та контент-аналіз літератури з питань досліджень неферментативних реакцій.

Результати дослідження. Не можна вважати, що на сьогоднішній час не ферментативні реакції є досконало дослідженими. Проте, відомо що є декілька видів реакцій, для проходження яких не $\epsilon$ потрібними ферменти. До таких реакцій належать глікорування, фруктозування, піридоксилювання, крім того, карбомілювання пептидів та ще декілька інших. 3 допомогою використання масс-спектрометрії було доведено, що такі реакції впливають на певні ланки патогенезу таких захворювань як цукровий діабет, хронічна хвороба нирок, цироз печінки. Підтверджено, що вони негативно впливають на перебіг цих захворювань.

Але, також було доведено, що деякі не ферментативні реакції також мають позитивний вплив на організм. Наприклад, вже відомо, що процес зорового сприйняття між опсином і ретиналем відбувається без участі ферментів, і однозначно не має негативного впливу, так як забезпечує сприйняття зору. Також, деякі елементи синтезу колагену відбуваються без участі ферментів, і також забезпечують позитивний вплив на організм, оскільки збагачують організм колагеном. Немає однозначної відповіді на те, позитивну чи негативну роль відіграє конформація пептидів, яка відбувається також без участі ферментів. Можливо, вона забезпечує процес старіння організму, проте це ще не вивчено детально.

Висновки. Таким чином, дослідження ролі не ферментативних реакцій в організмі людини справді є актуальною темою. Потрібне детальне їх вивчення, так як можливо, в 
подальшому можна буде впливати на них і відповідно на певні ланки патогенезу багатьох захворювань.

\section{Список використаних джерел:}

1. Armstrong D.(2002) Oxidative Stress Biomarkers and Antioxidant Protocols. New Jersey: Humana Press Inc.

2. Baldwin A.J., Knowles T.P., Tartaglia G.(2011) Metastability of native proteins and the phenomenon of amyloid formation.DC: J. Am. Chem. Soc.

3. Dobson C.M. (2003)Protein folding and misfolding. DC: Nature.

Колесник М.Р., студент кафедра хірургії №2

Харківський національний медичний університет, Украӥна

Науковий керівник: Лєсний В.В., канд. мед. наук

Харківський національний медичний університет, Украӥна

\section{РОЛЬ БАРІАТРИЧНОЇ ХІРУРГІЇ В ЛІКУВАННІ НЕАЛКОГОЛЬНИХ ЖИРОВИХ ЗАХВОРЮВАНЬ ПЕЧІНКИ}

Неалкогольне жирове захворювання печінки (НЖЗП) - це стан, який характеризується надлишковим накопиченням жиру у формі тригліцеридів в печінці (гістологічно стеатоз присутній більш ніж в 5\% гепатоцитів). Стан, коли до НЖЗП приєднується запалення називають стеатогепатитом (НАСГ). В основі захворювання полягають інсулінорезистентність, метаболічний синдром та активація цитокінових взаємодій, а потому оксидативний стрес та дисфункція мітохондрій - має місце так звана "гіпотеза багаторазових ударів". При подальшому прогресуванні хвороби, тканини печінки заміщується сполучною тканиною - III стадія НЖЗП, фіброз печінки [1]. Останньою, четвертою стадією є цироз печінки. Відповідно до (Weiß et al, 2014) фiброз прогресує до цирозу менше, ніж у 5\% випадків.

Нині немає єдиної концепції лікування хвороби, тож сучасне лікування спрямоване на вирішення пов'язаних з цим станом проблем: гіпертонію, дисліпідемію, діабет II типу та лікування ожиріння. Четверта стадія $є$ показанням для трансплантації печінки.

Принципово, НЖЗП є оборотним станом. І найголовнішим фактором тут є зниження ваги. Навіть помірне зниження ваги (4\% ваги тіла) є достатнім для редукції печінкового стеатозу у 56\% пацієнтів [3]. Два ретроспективних дослідження та одне проспективне показали, що у пацієнтів 3 діагностованим ожирінням після баріатричних операцій стеатоз печінки зменшився, а також знизилась і частка пацієнтів 3 фіброзом печінки. Сучасні дослідження показали, що баріатричні операції асоційовані з 69\% зниженням ризику розвитку цирозу печінки $[4,5]$.

Всі процедури можна умовно поділити на рестриктивні процедури, що зменшують об'єм шлунку (внутрішньошлунковий балон, бандажування шлунку, рукавна гастректомія), мальабсортивні операції, які створюють шунт із тонким кишківником, внаслідок чого кількість їжі, що засвоюється значно зменшується (біліопанкреатичне шунтування ти біліопанкреатичне відвернення зі створенням дуоенального карману) та гібридні процедури, як-от Roux-en-Y шунтування шлунку. Найчастіше виконують саме гібридні процедури, бо мальабсортивні операції потребують більших технічних можливостей, а також у пацієнтів після мальабсортивних операцій часто розвиваються нутрітивні дефіцити. Так, метою гібридних процедур є створення невеликого шлункового карману, який лімітує абсорбцію їжі, поєднуючись 3 проксимальним кінцем тонкого кишківника. Але на відміну від мальабсортивних операцій, 95\% тонкого кишківника 
інтактна [5]. До того ж гістологічні дані підтверджують більшу ефективність операції Rouxen-Y (Fakhry et al. 2019).

Дані біопсії печінки в пацієнтів після баріатричних операцій показали зменшення стеатозу (на 88\%), стеатогепатиту (на 59\%) та фіброзу (на 30\%), водночас біохімічний аналіз крові демонструє поліпшення рівнів АСАТ у $32 \%$ пацієнтів, АЛАТ у $62 \%$ пацієнтів [6]. С три основних механізми, які покращюють контроль глікемії при операціях Roux-enY та рукавної гастректомії. По-перше, раннє збільшення печінкової чутливості до інсуліну, по-друге, виникає пізніше, с поліпшення периферійної чутливості до інсуліну і, по-третє, покращення постпрандіальної секреції інсуліну (бо збільшується секреція GLP-1) [8]. Таким чином, баріатричні операції гібридного типу знижують ризик розвитку цирозу печінки, сприяють покращенню якості життя та прогнозові пацієнта.

\section{Список використаних джерел:}

1. World Gastroenterology Organisation (June, 2012) Non-Alcoholic fatty liver disease and Steatohepatitis WGO Global Guidelines NAFLD/NASH (long version), 3-24

2. Weiß, J., Rau, M., \& Geier, A. (2014). Non-alcoholic fatty liver disease: epidemiology, clinical course, investigation, and treatment. Deutsches Arzteblatt international, 111(26), 447-452. https://doi.org/10.3238/arztebl.2014.0447

3. Zelber-Sagi S, Lotan R, Shlomai A, Webb M, Harrari G, Buch A, Nitzan Kaluski D, Halpern Z, Oren R. Predictors for incidence and remission of NAFLD in the general population during a seven-year prospective follow-up. Journal of Hepatology. 2012 May; 56(5):1145-51

4. Laursen TL, Hagemann CA, Wei C, Kazankov K, Thomsen KL, Knop FK, Grønbæk H. Bariatric surgery in patients with non-alcoholic fatty liver disease - from pathophysiology to clinical effects. World J Hepatol 2019; 11(2): 138-149

5. Wirth, Keith M. MD*,; Sheka, Adam C. MD*,; Kizy, Scott MD*; Irey, Ryan MA, MS*; Benner, Ashley MPH; Sieger, Gretchen $\mathrm{BA}^{\S}$; Simon, Gyorgy PhD*; Ma, Sisi PhD; Lake, John MD ; Aliferis, Constantin MD, MS, $\mathrm{PhD}^{\ddagger}$; Leslie, Daniel MD*; Marmor, Schelomo PhD, MPH*; Ikramuddin, Sayeed MD, MHA, ${ }^{*}$ Bariatric Surgery is Associated With Decreased Progression of Nonalcoholic Fatty Liver Disease to Cirrhosis, Annals of Surgery: March 27, 2020 - Volume Publish Ahead of Print - Issue - doi: 10.1097/SLA.0000000000003871

6. Fakhry TK, Mhaskar R, Schwitalla T, Muradova E, Gonzalvo JP, Murr MM. Bariatric surgery improves nonalcoholic fatty liver disease: a contemporary systematic review and meta-analysis. Surg Obes Relat Dis. 2019;15(3):502-511. doi:10.1016/j.soard.2018.12.002

7. McCarty TR, Echouffo-Tcheugui JB, Lange A, Haque L, Njei B. Impact of bariatric surgery on outcomes of patients with nonalcoholic fatty liver disease: a nationwide inpatient sample analysis, 2004-2012. Surg Obes Relat Dis. 2018;14(1):74-80. doi:10.1016/j.soard.2017.09.511

8. Hafeez S., Bariatric surgery as potential treatment for non-alcoholic fatty liver disease: a future treatment choice or choice by chance?. 201329 (1), https://doi.org/10.1155/2013/839275 


\title{
СЕКЦІЯ 7.
}

\section{ПСИХОЛОГІЧНІ ТА СОЦІОЛОГІЧНІ НАУКИ}

\author{
Червінко Лілія Михайлівна, студентка 4 курсу \\ Наиіональний університет “Острозька академія”, Україна

\section{ВПЛИВ МОТИВАЦІЇ НА ПРОКРАСТИНАЦІЮ У СТУДЕНТІВ}

Сучасне суспільство диктує велику кількість вимог для того щоб бути першокласним спеціалістом: критичне мислення, вміння аналізувати інформацію, нестандартне вирішення різного роду ситуацій, високий рівень рефлексії, швидке виконання поставлених задач, професіоналізм та ряд інших.

Вище перерахованим факторам може сприяти високий рівень мотивації та відсутність прокрастинації. Відомо, що студенти під час навчання стикаються з великою кількістю завдань, часто можна помітити, що одні виконуються одразу ж із достатнім запалом, а інші розтягуються на довгий період часу та не завжди досягають свого завершення.

Мотивація є рушійною силою будь якої діяльності людини, відповідно під час навчання вона $є$ основною запорукою високої успішності та професійного становлення. Проте не всі можуть досягнути максимально рівня, однією з причин що цьому не сприяє $є$ феномен прокрастинації.

Наукове вивчення питання мотивації іiі формування та розвитку у студентів не $\epsilon$ новим. Серед вітчизняних вчених які цікавилися цим питанням можна виділити О. Леонтьєва, Ф. Нємова, Б. Ломова та Є. Ільїна. У свої роботах вони говорять, що мотивація описує цілеспрямованість дій особистості, організацію діяльності яка в основному спрямована на досягнення та реалізацію мети. Науковці вивчали не лише загальну структуру мотивації ай iї окремі компоненти, такі як прагнення, потреби, ідеали, установки тощо (С. Рубінштейн, Ф. Олпорт, С. Максименко, К. Левін, Д. Брунер, I. Пасічник, А. Маслоу, Г. Костюк, В. Ковальов.) Ряд дослідників говорили, що місце яке займає людина в соцікультурному середовищі в великій мірі залежить від виду мотиваційної діяльності: уникнення невдач чи досянення успіху (X. Гекгаузен, Д. Макклеланд та інші.) Також серед науковців присутні думки, що визначають мотивацію як певний стан особистості та відповідний рівень її прагнень який спрямований на те, щоб реалізувати свої мотиви [1].

В. Давидов, В. Рєпкін, О. Дусавицький розглядають питання навчальної мотивації $з$ точки зору здійснення навчальної діяльності студента. Такі дослідники як Б. Ломов, Е. Кузьмін та К. Платонов під мотиваційною сферою індивіда вбачають набір стійких мотивів, які складаються із певної ієрархії та визначають спрямованість особистості [6]. Для того щоб краще розуміти сутність поняття мотивації, доцільно розглянути термін “мотиву”. Серед пояснень у словнику можна зустріти наступні: 1) набір внутрішніх або зовнішніх умов які стимулюють активність суб'єкта та детермінують ії спрямування; 2) спонукання до будь-якої діяльності, яка пов’язана із задоволенням потреб індивіда; 3) усвідомлена причина, яка знаходиться в основі визначення дій та вчинків які здійснює особистість [3].

Науковці виділять ряд мотивів, які керують діяльністю особистості Д. Маккеланд першим ввів термін "мотивація досягнення" під ним він розумів критерії якості діяльності та їх співвідношення [8]. Тобто чим вищий рівень мотивації в особи, відповідно до цього тим більше зусиль вона буде прикладати, щоб досягнути бажаної цілі.

Проте серед вчених немає однозначної думки на рахунок того які є види мотивів. Для прикладу в свої роботах С. Занюк виокремлює наступні: мотив влади; мотив 
самоствердження; мотив афіліації; мотив досягнення; мотив саморозвитку; мотив ідентифікації себе з іншою людиною [2]. Різні класифікації напряму залежать від наукових інтересів вченого, його специфіки діяльності та завдань які він хоче виконати [7]. Проте незважаючи на велику різноманітність різного роду класифікації, які відомі на сьогоднішній момент в кожній наявний мотив досягнення успіху.

На перевагу цьому мотиву також науковці виокремлють мотив уникнення невдач. Наприклад якщо людина зосереджена на досягненні успіху то вона не відчуває страху перед тим, що може зазнати краху та старається докласти максимум зусиль щоб досягнути бажаного і навпаки, якщо в особистості домінує мотив на уникнення невдач то прагнення досягати успіху в неї слабо виражене. Однак є ряд науковців які стверджують протележне, вони вважають якщо індивід із яскраво вираженим прагненням досягати успіху, може мати не менш сильне бажання уникати невдач, особливо якщо вони супроводжуватимуться сильними переживаннями та викликатимуть стресову ситуацію. Відповідно до цього можна говорити проте, що прокрастинація у студентському віці частіше за все буде простежуватися в осіб в яких переважає мотив на уникнення невдач. Оскільки термін "прокрастинація" у науці характеризується як добровільне відкладання бажаних дій на певний період часу, незважаючи на можливі майбутні наслідки.

Тому доречно розглянути розуміння поняття прокрастинації різними дослідниками. Серед пострадянських та західних вчених прокрастинацію розглядають як вище було згадано «тенденцію відкладати виконання запланованих дій, незважаючи на можливі негативні наслідки для того, хто їх відкладає». Вперше в науковому середовищі описання феномену прокрастинації було здійснено в 1977 році. П. Рінгенбах в своїй книзі «Прокрастинація в житті людини» розкрив це явище [5].Клінічні спостереження дослідників описали А. Елліс та В. Кнаус в своїй праці «Подолання прокрастинації». Варто згадати і працю Дж. Брука та Л. Юен під назвою «Прокрастинація: що це таке та як із нею боротись», в основі якої також були покладені клінічні спостереження.

Дж Харіотт та Дж Феррарі доводять, що приблизно кожна 3-4 людина страждає він певного рівня прокрастинації, також варто відмітити, що за останніх 30 років кількість індивідів, у діяльності яких простежується схильність до прокрастинації неухильно збільшується $[9,10]$.

У науковій літературі існує ряд досліджень в яких намагалися дослідити основні причини виникнення прокрастинації. К. Лей аналізуючи навчальний процес, виділяє один із чинників, який найбільше провокує формування прокрастинації - це невизначеність початкового етапу роботу. Наприклад, студенти отримують достатньо тривалий проміжок часу для виконання певного завдання, а у зв'язку з тим, що в них немає цілісної структури роботи вони відкладають його виконання до останнього [12].

Такі науковці як П. Маккарті, Л. Хайкок та К. Скай здійснили дослідження основною метою якого було виявлення чинників та засобів зменшення прокрастинації у студентів, у ході цього дослідження вони дійшли наступних висновків:

1. Основними чинниками, що викликають академічну прокрастинацію є: брак мотивації, а саме домінування мотиву уникнення невдач, лінощі, надмірна самовпевненість, страх зазнати краху, соціальні проблеми, негаразди у сім'ї, низький рівень комунікації, наявність зовнішніх факторів, що відволікають.

2. Наявність академічної прокрастинації призводить до низького рівня успішності, збільшення тривожності, також можлива поява комплексу неповноцінності, та як наслідок - відсутність бажання до навчання [11].

За результатами свого дослідження В. Бикова говорить, що прокрастинація серед студентською молоді найчастіше появляється під час ситуацій які зв'язані 3 інтелектуальною напругою та вимагають високого рівня самоорганізації, планування власного часу, недостатнього рівня мотивації або переважання мотиву до уникнення 
невдач, простежуючись у рамках домінуючої поведінки серед студентської вибірки прокрастинація виступає як симбіоз емоційно-орієнтованої статегією та копінгу, який спрямований на уникнення діяльності [4 ].

Таким чином проаналізувавши наукову літературу, що стосується феноменів “мотивації” та “прокрастинації”, не можливо не помітити, що в залежності від того який мотив домінує у діяльності індивіда: досягнення успіху або уникнення невдач, можна говорити про наявність прокрастинації. Порівнявши основні характеристики, що притаманні особам в яких переважає другий мотив та опис людини, що схильна прокрастинувати можна вважати те, що мотивація здійснює вплив на появу прокрастинації.

\section{Список використаних джерел:}

1. Болгаріна В., Гуменюк Л. Вивчення мотивації учіння засобами педагогічної соціології. Педагогіка і психологія. 1997. № 4. С. 7-14.

2. Занюк С. Психологія мотивації : [Навч. Посібник] / С. С. Занюк. - Київ : Либідь, 2002.304 с.

3. Психологічний словник / [за ред. В.І. Войтка]. - Київ: Вища школа, 1992. 216 с.

4. Быкова Д. Прокрастинация как проявление эмоционально- ориентированного и ориентированного на избегание стилей копинга / Д.В. Быкова // Психология совладающего поведения : материалы II Междунар. науч.-практ. конф.. - Кострома : КГУ им. Н. А. Некрасова, 2010. С. 194-196.

5. Варваричева Я. Феномен прокрастинации: проблемы и перспективы исследования / Я. И. Варваричева // Вопросы психологии. 2010. № 3. С.121-131.

6. Дусавицкий А. Развитие личности в студенческом коллективе в зависимости от сформированности учебно-профессиональных интересов: учебно-методическое пособие. - Харьков: ХНУ имени В.Н.Каразина, 2012. $32 \mathrm{c}$.

7. Ильин Е. Мотивация и мотивы / Е. Н. Ильин. - СПб : Питер, 2000. -512

8. Макклеланд Д. Мотивация человека / Д. Макклеланд. - Санкт-Петербугр : Питер, 2007. 672 с.

9. Blunt A. Task evasiveness and procrastination: a multidimensional approach to task evasiveness across stages of personal projects / A. K. Blunt, T. A. Pychyl // Personality and individual difference. 2000. №28. P. 153-167.

10.Ferrari J. Procrastination and task avoidance: Theory, research and treatment / J. R. Ferrari, J. L. Johnson, W. G. McCown. - N.Y.: Plenum Press, 1995. P. 137-167.

11.Haycock L., McCarthy P., Skay C. Procrastination in college students: The role of selfefficacy and anxiety / Haycock L., Актуальні проблеми психології T. ХІ Випуск 18321 McCarthy P., Skay C.// Jou. of Counseling and Development. 1998. P.24-39.

12. Wolters C. «Understanding Procrastination From a SelfRegulated Learning Perspective» / C.A. Wolters // Journal of Educational Psycology, 2003. №1. P. 52-58.

Василик Ольга Михайлівна, студентка VI курсу

Тернопільський національний економічний університет, Україна

Науковий керівник: Фурман А.В., д.пс.н. професор

Тернопільський національний економічний університет, Украйна

\section{ДІАГНОСТИЧНІ МЕТОДИ В РОБОТІ СОЦІАЛЬНОГО ПРАЦІВНИКА}

Діагностична функція є провідною у соціальній роботі як різновид професійної діяльності, спрямованої на забезпечення належного соціального, культурного та матеріального рівня життя членів суспільства та надання допомоги різним категоріям людей.

Сьогодні діагностика як спосіб отримання вичерпної інформації про досліджуваний процес чи об'єкт застосовується в різних галузях діяльності та має різні цілі. Варто зазначити, що в соціальній роботі найчастіше застосовуються такі види діагностики: 
соціальна, медична, соціально-психологічна, соціально-педагогічна.

Метою роботи є проаналізувати діагностичні методи які застосовуються в роботі соціального працівника. Завданням дослідження є:

- розкрити термін "діагностика";

- охарактеризувати методи діагностики соціального працівника.

Термін «діагностика» використовується в медицині для позначення процесу розпізнавання хвороби, постановки діагнозу[1].

Говорячи про соціальну діагностику, ми маємо на увазі або одиничне дослідження соціальної ситуації клієнта, якому соціальний працівник повинен надати допомогу, або необхідний етап будь-якого впливу в соціальній роботі, технологічний імператив соціального обслуговування, або сукупність наукових методів, що обгрунтовують правильність отриманої інформації. Відповідно, цією діяльністю займаються фахівці різних органів і установ, на різних рівнях і з різними цілями.

Методи соціальної діагностики грунтуються на ряді принципів, як загальних для всіх соціальних наук, так і специфічних. Насамперед це принцип об'єктивності - дослідження не повинні обгрунтовуватися на таких факторах як бажання і переваги третьої особи, а також соціальний працівник повинен протистояти таким факторам як не компетентність, сімейний досвід, власні забобони.

У зв'язку з цим необхідно також використовувати принцип верифікації соціальної інформації, тобто встановлення її вірогідності, можливості перевірки за допомогою інших процедур або інших джерел даних.

Принцип системності в діагностиці застосовується задля визначення джерела i способу вирішення життєвої проблеми клієнта, необхідно проаналізувати його мікросоціальне середовище, його сімейні взаємини; необхідно також мати уявлення про інтелектуальний рівень і особливості характеру клієнта, про стан його здоров'я.

Специфічним принципом діагностики в соціальній роботі можна вважати принцип клієнтоцентризму, тобто розгляд всіх сторін соціальної дійсності, усіх зав'язків і опосередкування соціальної ситуації з погляду інтересів і прав індивіда або групи. Інші соціальні інститути захищають інтереси держави і суспільства, їхніх окремих установ або організацій. [3].

Серед загальних вимог, яким повинні відповідати методи діагностики які застосовує в своїй практиці соціальний працівник, варто назвати валідність, надійність, однозначність і точність. Є ряд і додаткових, спеціальних вимог, пропонованих до вибору діагностичних методів у соціальній роботі, які дають змогу надати більше інформації працівнику про клієнта.

Головними правилами вибору метода є:

- проста опитувальна методика, дозволить швидко та надійно одержати необхідний результат;

- доступність для усіх, необхідність цього методу використання мінімум фізичних i психологічних умов, чіткість і швидкість поставленої умови дозволить одержати необхідний матеріал;

- технології в досліджені повинні бути якісні і зрозумілі. Вона повинна набудовувати клієнта на довірче відношення до соціального працівника, на співробітництво, що виключає виникнення побічних мотивів, здатних негативно вплинути на результати;

- обстановка й умови проведення діагностики не повинні відволікати клієнта від співучасті в діагностиці.

Адже діагностика в соціальній роботі розглядають, перш за все, як інструмент, котрий дає управлінським органам необхідну інформацію, на основі якої розробляються різні соціальні прогнози та проекти, вивчається громадська думка та морально-психологічний клімат у суспільстві. 
Соціальна діагностика - досить складний і відповідальний вид діяльності фахівців соціальної роботи. Вона вимагає відповідної професійної майстерності, оскільки торкається долі людей, різних соціальних груп. На основі соціального діагнозу виділяються пріоритети і здійснюється вибір у наданні тієї або іншої соціальної допомоги.

\section{Список використаних джерел:}

1. Технологии социальной работы: учебник/ под общ. ред. проф. Е.И. Холостовой - М.: ИНФРА-М, 2003. - $400 \mathrm{c}$.

2. Соціальна робота: технологічний аспект / за ред. проф. А.Й. Капської / Київ: ДЦССМ, 2004 - 364 с.

3. Социальная работа / Под ред. В.И. Курбатова. - Ростов-на-Дону: "Феникс", 1999. - 576 с.

4. Соціальна робота в Україні: навчальний посібник / І.Д. Звєрєва, О.В. Безпалько, С.Я. Харченко та ін., за заг. ред. І.Д. Звєрєвої, Г.М. Лактіонової - Київ: ДЦССМ, 2004. - 256 с.

Костіна Аліна Сергіївна, здобувач вищої освіти ННІ педагогічної освіти, соціальної роботи і мистецтва

Черкаський національний університет імені Богдана Хмельнищького, Украйна

Науковий керівник: Архипова Світлана Петрівна, докт. пед. наук, професор кафедри соціальної роботи та соціальної педагогіки

Черкаський національний університет імені Богдана Хмельницького, Україна

\section{ІНФОРМАЦІЙНО-КОМУНІКАЦІЙНІ ТЕХНОЛОГІЇ В ОСВІТІ ДОРОСЛИХ}

У кінці XX - на початку XXI століття людство вступило в нову епоху свого розвитку - інформаційну. 3'явилось нове поняття «інформаційне суспільство» як історична фаза розвитку цивілізації, коли життя та діяльність людини насамперед пов'язані зі створенням, переробкою та використанням інформації [2]. Інформаційна революція і формування суспільного устрою нового типу - інформаційного суспільства - висувають інформацію та знання на перші позиції. Вислів: «Хто володіє інформацією - володіє світом!» стає не просто висловом, а підтвердженням сучасних глобалізаційних процесів кожного індивіда нашого соціума, кожного висококваліфікованого фахівця будь-якої сфери.

Освіта дорослих - це одна 3 ключових ланок самоосвіти та саморозвитку суспільства. Оскільки практика навчання і виховання дорослих, набуття ними нових навичок, умінь та знань пов'язана з новим працевлаштуванням чи з іншого роду зміною діяльності - це спосіб розвитку суспільства, покращення процесу розвитку та творення нових тенденцій сучасності.

Варто зауважити, що розбудова повнофункціональної сучасної освіти протягом життя на основі інформаційних технологій привела до появи відкритої системи освіти - освіти без бар'єрів, доступної для всіх бажаючих навчатися [1].

Нині кожна особа, яка прагне знайти себе, свою роль в суспільстві, професійному становленні, може обрати для себе зручний спосіб самонавчання та саморозвитку. Для цього варто мати лише зручний девайс для користування та доступ до мережі Інтернет. Саме інформаційно-комунікаційні технології дозволяють кожному з нас опанувати будьякий бажаний навик, дізнатися все, що необхідно, пройти цікавий вебінар або онлайнкурси. Саме сучасні виклики нашого часу вимагають кожній особі бути «просунутим» користувачем та опановувати інформаційно-комунікаційні технології для їх правильного застосування в своїй освіті. Варто зазначити, що для включення дорослих учнів в процес навчання, для більшої наочності, для кращого ефекту засвоєння інформації досить корисно 
та необхідно застосовувати інструменти та засоби інформаційно-комунікаційних технологій.

3 метою дослідження ролі інформаційно-комунікаційних технологій в освіті дорослих нами було опитано 67 осіб дорослого віку. Інструментом опитування стала авторська, розроблена анкета «Роль інформаційно-комунікаційних технологій в освіті дорослих», яка була розміщена в інтернет доступі за допомогою google-forms.

В опитуванні взяли участь 45 жінок та 22 чоловіків. Вікові межі яких коливались від 28-57 років. Загалом, 82,1 \% респондентів зазначили, що використовують Інтернет для пошуку необхідної інформації. 3 них 53,2 \% осіб при цьому використовують комп’ютер або ж ноутбук, 15,5 \% - телефони, 13,4 \% - планшети. Це дає зрозуміти, що на сьогодні уміння користуватися девайсами для просторів Інтернет-мережі є досить поширеним явищем не лише серед підлітків, але й дорослого населення (Рис. 1.).

Отримані дані демонструють нам, що переважна більшість користувачів використовують комп'ютери або ж ноутбуку для пошуку необхідної інформації, навчання тощо. Це говорить про незмінну значимість цих гаджетів в освітньому процесі, оскільки це дає змогу зручно, комфортно вивчати все, що забажаєш, в будь-якому місці та часі доби.

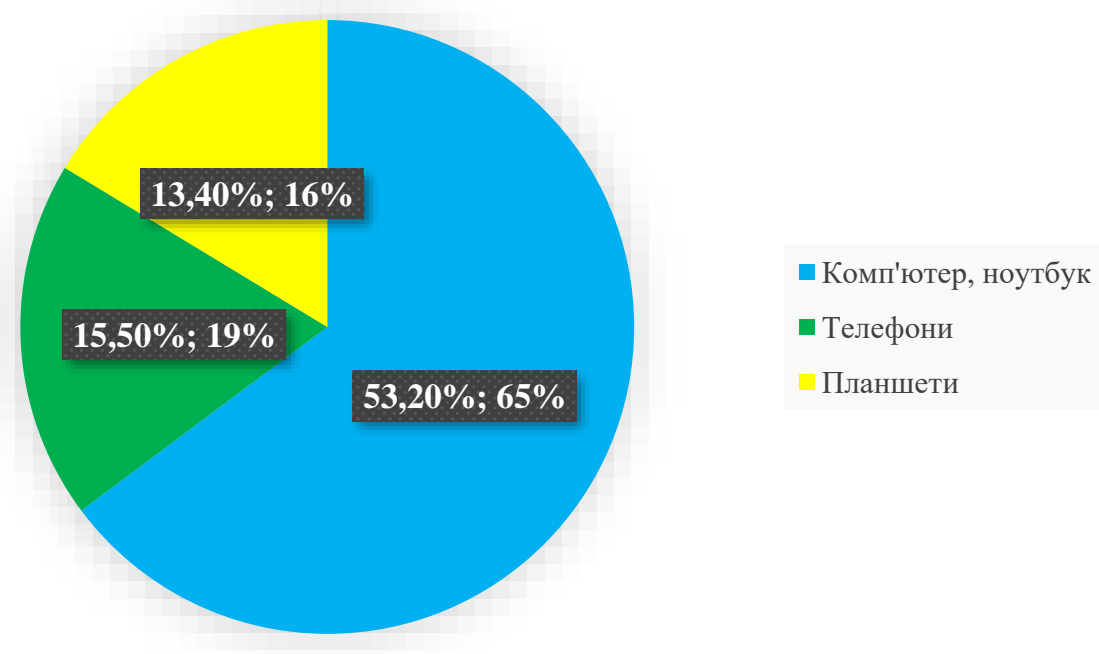

Рис. 1. Співвідношення девайсів користувачів мережі Інтернет

Цікавими $є$ отримані дані щодо розділення даних про способи самонавчання респондентів. Переважна більшість репондентів $(64,7 \%)$ зазначили, що віддають перевагу самостійному пошуку необхідної інформації для навчання, $12,5 \%$ навчаються за допомогою онлайн-курсів, вебінарів тощо, 4,9\% зазначили, що воліють займатися онлайн з групою, мати живий діалог та обговорення невідомих питань. Це ще раз підтверджує той факт, що в наш час багато осіб віддають перевагу комфортному, вільному навчанню та самостійним формам навчання. Що говорить про одну з передових ролей інформаційнокомунікаційних технологій не лише в глобалізованому суспільстві, але й в освіті дорослого населення. Часи змінились, відбулась трансформація не лише поглядів на речі, державні устрої, але й на модель освіти та свободу вибору способу навчання.

На нашу думку, це ті передові зміни, до яких суспільство так довго йшло, зрозуміло, що Україна ще в процесі узгодженості цієї легкості в освіті із менталітетом та установками минулих часів, проте досвід передових країн Європейського Союзу, їх організація освітнього процесу, доводить, що це можливо і це лише питання часу.

Також за порадами респондентів, ми скомпонували добірку основних джерел, які можна використовувати для самонавчання та саморозвитку, аткож додали сюди й власні джерела, якими корисуємося при нагоді (Табл. 1.). 
Перелік сайтів для саморозвитку і самоосвіти дорослих

Таблиия 1

\begin{tabular}{|c|c|c|}
\hline № & $\begin{array}{c}\text { 3міст (тематика розміщених } \\
\text { матеріалів, тощо) }\end{array}$ & Web-adpeca \\
\hline 1. & $\begin{array}{l}\text { Пропозиції психологічних тренінгів } \\
\text { саморозвитку. Рекомендації щодо } \\
\text { саморозвитку, що надаються у статтях, } \\
\text { публікуються в блозі. }\end{array}$ & $\begin{array}{l}\text { http://daoping.com.ua/uk/trening/samorazvitie- } \\
\text { lichnosti-i-nekotorye-principy.html }\end{array}$ \\
\hline 2. & $\begin{array}{l}\text { Психологічні } \text { поради } \\
\text { саморозвитку у вигляді статей, фільмів, } \\
\text { літератури, відеоматеріалів. }\end{array}$ & http://www.selfcreation.ru/ \\
\hline 3. & $\begin{array}{l}\text { Пропозиції щодо арт-терапії для } \\
\text { гармонізації } \\
\text { внутрішнього стану та } \\
\text { натхнення для внутрішнього зростання. }\end{array}$ & http://nathnennya.com/ua/info/ \\
\hline 4. & $\begin{array}{l}\text { Психологічна інформація щодо } \\
\text { саморозвитку у вигляді текстових, } \\
\text { аудіо, відео-матеріалів. Рекомендації } \\
\text { щодо перегляду фільмів, читання книг } 3 \\
\text { питання саморозвитку }\end{array}$ & http://samorozvytok.info/ \\
\hline 5. & $\begin{array}{l}\text { Інформація психологічного та } \\
\text { духовного змісту щодо саморозвитку у } \\
\text { вигляді текстових, аудіо-, відео- } \\
\text { матеріалів. Поради щодо застосування } \\
\text { наданої інформації в практичному житті } \\
\text { в різних сферах людської діяльності. }\end{array}$ & http://key-rich.com/ \\
\hline 6. & $\begin{array}{l}\text { Пропозиції } \text { щодо саморозвитку та } \\
\text { самоосвіти } \\
\text { програмами. }\end{array}$ & http://intensiv.kiev.ua/index_ua.php \\
\hline 7. & $\begin{array}{l}\text { Інформація у вигляді статей, порад, } \\
\text { рекомендацій щодо саморозвитку, яка } \\
\text { має психологічну, духовну, виховну } \\
\text { спрямованість. }\end{array}$ & http://www.vitamarg.com/ \\
\hline 8. & $\begin{array}{l}\text { Пропозиції щодо тренінгів, семінарів, } \\
\text { лекцій, майстер-класів } \\
\text { саморозвитку: розклад занять, перелік } \\
\text { експертів, тренерів, консультантів; } \\
\text { перелік напрямків саморозвитку } \\
\text { (центри, школи, програми та ін.); } \\
\text { перелік сайтів, які містять інформацію } \\
\text { щодо саморозвитку. Інформація } \\
\text { питань саморозвитку особистості у у } \\
\text { статтях, на форумі. }\end{array}$ & http://samopoznanie.ru/ \\
\hline 9. & $\begin{array}{l}\text { Психологічна інформація, що сприяє } \\
\text { саморозвитку у вигляді статей, порад, } \\
\text { відео-тренінгів, аудіо-ессе, книг, } \\
\text { фільмів, тощо. }\end{array}$ & http://www.vernikova.com/ \\
\hline 10. & 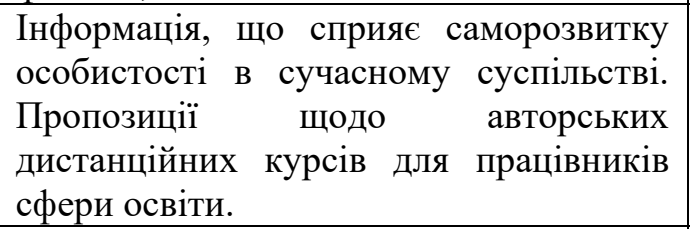 & http://vgs1949.ru/ \\
\hline 11. & $\begin{array}{l}\text { Статті, що містять рекомендації щодо } \\
\text { саморозвитку та самоосвіти. }\end{array}$ & http://my-orbita.com/ \\
\hline
\end{tabular}


Отже, в умовах бурхливого розвитку інформаційних технологій застосування IКТзасобів та ІКТ-методів навчання дає змогу споживачам освітніх послуг самим обирати програми та модулі навчання, а також час та способи їхнього опанування. Кожний індивідуум, використовуючи як традиційну систему освіти, так і безперервну освіту на базі IКТ, залишаючись на одному й тому ж формальному освітньому рівні, може вдосконалювати свою професійну кваліфікацію і майстерність; підійматися по ступенях і рівнях професійної освіти; не тільки продовжити, а й змінити профіль освіти.

\section{Список використаних джерел:}

1. «Osvita protiahom zhyttia: svitovyi dosvid i ukrainska praktyka». Analitychna zapyska [«Education throughout life: world experience and Ukrainian practice». Analytical note]. Natsionalnyi instytut stratehichnykh doslidzhen - National Institute for Strategic Studies. Retrieved from http://www.niss.gov.ua/articles/252 [in Ukrainian].

2. Коваль Т. I. Професійна підготовка 3 інформаційних технологій майбутніх інженерів-економістів: монографія. Київ: Ленвіт, 2007. 264 с.

Кулик Ганна Вікторівна, студентка V курсу спеціальності «Психологія» факультету політико-інформаційного менеджменту Національний університет «Острозька академія», Украӥна

Науковий керівник: Шугай Марія Анатоліївна, кандидат психологічних наук, доцент кафедри психології та педагогіки Національний університет «Острозька академія», Україна

\section{ОСОБЛИВОСТІ СОЦІАЬНО - ПСИХОЛОГІЧНОЇ АДАПТАЦЇ̈ ДІТЙ СТАРШОГО ДОШКІЛЬНОГО ВІКУ 3 ВИСОКИМ РІВНЕМ ТРИВОЖНОСТІ}

Дитинство та юність - це основна фаза ризику розвитку симптомів та синдромів тривожності, яка може варіюватися від перехідних легких симптомів до повномасштабних тривожних розладів. Тривога стосується реакції мозку на небезпеку, подразників, яких організм активно намагатиметься уникати.

Актуальність проблеми адаптації дітей до дитячого садка підтверджують наукові дослідження багатьох відомих психологів і педагогів, на думку яких, ступінь вираженості адаптаційних порушень пов'язаний 3 такими факторами: організацією навчальновиховного процесу в ДНЗ; попередніми умовами виховання, під впливом яких формується вища нервова діяльність дитини; своєрідністю міжособистісних взаємин дорослих і дітей; рівнем прихильності дитини до матері; соціальними умовами тощо.

Дошкільний навчальний заклад $є$ інститутом соціалізації дітей на першій іï стадії, а група однолітків представляє собою форму суспільства, де дитина дошкільного віку знайомиться з соціальними нормами, оволодіває конкретними соціальними навиками для взаємодії з соціумом. Тому важливе значення має виявлення індивідуальних особливостей адаптаційних резервів саме в дошкільному віці, коли компенсаційні можливості дитини ще формуються і $є$ можливість запобігти формуванню стійких патологічних проявів, а також сприяти його подальшій соціально-психологічній адаптації на наступних рівнях психологічного та соціального розвитку як особистості. Необхідне чітке концептуальне розрізнення понять «тривоги» як стану і «тривожності» як риси, властивої особистості. Більш характерною, на наш погляд, є тенденція розглядати тривогу як особливий емоційний стан, що характеризується суб'єктивними відчуттями занепокоєння, напруги, 
похмурих передчуттів, а з фізіологічної боку супроводжується активізацією вегетативної нервової системи.

Тривожність у дітей в перші роки життя може проявлятися у вигляді емоційної лабільності разом із загальним зниженим фоном настрою, плаксивістю, ослабленням апетиту і т.д. Іншою причиною дитячої тривожності, $є$ дисгармонія сімейного виховання у вигляді деструктивних відносин в системі дитина - батьки. Виділяються чотири батьківські установки і відповідні їм типи поведінки: «Прийняття і мотив», що сприяють почуттю безпеки і нормальному розвитку особистості; «надмірна опіка» та «зайва вимогливість і явне відторгнення», що ведуть до агресивності і до обмеження спектра емоційних проявів.

Е. Савіна називає неправильне виховання і несприятливі відносини дитини 3 батьками, особливо з матір'ю. Дитяча тривожність може бути наслідком і симбіотичних відносин дитини з матір'ю, коли мати відчуває себе єдиним цілим з дитиною, намагаючись захистити іiі від труднощів і неприємностей життя. [1]

Тривогу іноді розглядають як форму адаптації організму в умовах гострого або хронічного стресу проте тривога, очевидно, є не стільки формою психічної адаптації, скільки сигналом, який свідчить про її порушення, який активізує адаптивні механізми. Таким чином, тривога може грати захисну і мотиваційну роль. 3 виникненням тривоги пов'язують посилення поведінкової активності, зміна характеру поведінки або включення механізмів інтрапсихічної адаптації, причому зменшення інтенсивності тривоги сприймається як свідчення достатності та адекватності реалізованих форм поведінки, як відновлення раніше порушеної адаптації.

Вивченням проблеми соціально-психологічної адаптації займалися Г. Айзенк, Г.Гартман, А. Маслоу, Ф.Б. Березін, В.І Медведєв, А.А. Налчаджан, Ж.Піаже А.А. Реан та ін.

Адаптаційний процес проходить ряд стадій (стадії переорієнтації, взаємної терпимості, акомодації, за допомогою механізмів соціально-психологічної адаптації формується захисно-адаптаційний комплекс який, в свою чергу, проявляється в поведінковій реакції, так і в психічній регресії, адаптивній активності уяви. Кінцевим підсумком процесу соціально-психологічної адаптації може бути як, у вираженні конформності до вимог суспільства або прояв гнучкості та ефективності при зустрічі 3 новими i потенційно небезпечними умовами середовища, так i дезадаптація, що визначається як стійко-ситуативна, тимчасова або загальна нездатність до адаптації.

Ознаками адаптивності дитини в умовах ДНЗ $є$ емоційна задоволеність, вміння свідомо відповідати встановленим правилам, встановлювати і зберігати міжособистісні зв'язки, займати певне положення в системі міжособистісних відносин, адекватність самооцінки і механізмів психологічного захисту. Соціальні та біологічні фактори соціально-психологічної адаптації ведуть до прояву ознак дезадаптації таких, як: 1) переживання особистістю тривалих зовнішніх і внутрішніх конфліктів без знаходження психологічних механізмів і форм поведінки, необхідних для їх вирішення; 2) дистрес; 3) наявність постійної тривоги, агресивності, стану фрустрації.[2]

Не адаптовані діти, на відміну від однолітків які вдало адаптувались, характеризуються нижчим рівнем соціальної зрілості, дисгармонійним функціонуванням мотиваційної сфери, проявом «афекту неадекватності» і «психогенного перекрученого образу Я» , недостатністю самоконтролю (Е.О. Смирнова, О.І. Політика). Такі діти більшою мірою схильні до депресивного стану, легко впадають у відчай через невдачі. [2]

Тривога, на думку А. М. Прихожан, є емоційним станом, а тривожність - це вже певне емоційно-особистісне утворення людини яке містить у собі три аспекти : когнітивний, емоційний та операційний. Проте, деякий рівень тривожності притаманний кожній людині і є певною нормою для всіх та є допомогою для нормального пристосування у соціумі. Наявність тривожності як саме стійкого утворення, свідчить про те, що у людини наявні 
порушення у особистісному розвитку, саме ця тривожність і заважає гармонійному психічному розвитку особистості, ії спілкуванню та діяльності. [3]

Механізм виникнення тривожності у дітей на основі теорії прихильності показує, що якість прихильності, що формується в ранньому дитинстві, визначає подальший розвиток всіх пізнавальних, комунікативних та емоційних можливостей дитини.

Початок відвідування дитиною дошкільного навчального закладу - це не тільки нові умови життя і діяльності, режиму і харчування, але і нові контакти і обов'язки. Це досить складний період у житті кожної дитини, що вимагає від неї психологічних і фізичних форм пристосування. Процес адаптації дитини до дитячого садка часто виявляється важким випробуванням, яке супроводжується численними проявами неадекватної поведінки, різними захворюваннями, порушеннями сну і апетиту, погіршенням комунікативної діяльності тощо.

Кожна дитина по-різному переносить труднощі, що виникають в період адаптації. Так, проведені дослідження (Л. Голубєва, Н. Ватутіна, А. Мишкіс, Р. Тонкова-Ямпільська,), показали, що цей процес залежить від певних факторів стану здоров'я та рівня розвитку дитини; віку дитини; особливостей нервової системи і її типу; фактора ризику біологічного і соціального анамнезу; рівня тренування адаптаційних можливостей; індивідуальних особливостей дитини в сфері спілкування; типу сім’ї та стилю виховання в сім'ї; типу вищої нервової системи. [1]

Відповідно до емпіричної частини нашого дослідження, нами будуть використовуватись такі методики : методика для діагностики тривожності (Р. Сірса) ,яка дасть нам змогу за допомогою спостереження визначити рівень тривожності у дитини; проективна методика "Вибери потрібне обличчя" (Р. Теммл, М. Дорки і В. Амен) свідчитиме нам про рівні тривожності старших дошкільників. За допомогою методу спостереження, будемо перевіряти наскільки дитина адаптувалась до умов ДНЗ. I на завершення, складемо та проведемо корекційну програму по зниженню тривожності у дітей старшого дошкільного віку та перевіримо ії ефективність.

Висновки. Отже, тривожність може допомагати нам як захисний механізм, проте i може заважати нашому подальшому розвитку як особистості.

Соціально-психологічна адаптація дітей старшого дошкільного віку визначається як процес становлення динамічної рівноваги між потребами індивіда і вимогами соціального середовища, реалізованого у вигляді активного пристосування до умов соціального середовища, до існуючих у суспільстві вимог та соціальних норм. В теоретичній частині нашого дослідження ми проаналізували поняття тривожність та його вплив на формування особистості. Також, виявили ознаки адаптивності дитини в умовах ДНЗ та наслідки дезадаптації дитини.

Перспективою нашого дослідження є визначення рівнів тривожності дітей старшого дошкільного віку та умови які сприятимуть соціально - психологічній адаптації; розробка та проведення корекційної програми, рекомендацій батькам та вихователям ДНЗ щодо зменшення рівня тривожності дитини.

\section{Список використаних джерел:}

1. Астапов В.М. Тревожность у детей. М.: ПЕРСЭ, 2008. - 160 с.

2. Васильева Н. К вопросу о социально-психологической адаптации. Дошкольное воспитание. 2010. № 8. С. 16-18.

3. Прихожан А. М. Причины, профилактика и преодоление тревожности. Психологическая наука и образование. 1998. С. 12-22. 
Шморгай Екатерина Олеговна, получатель высшего образования факультета компьютерной инженерии

Харьковский национальный университет радиоэлектроники, Украина

\section{ПСИХОЛОГИЧЕСКИЕ ПРЕПЯТСТВИЯ ДЛЯ ОСУЩЕСТВЛЕНИЯ ПЕРЕМЕН}

Введение. В моей работе лежит исследование вопроса успешности, а также описание психологических препятствий в процессе личностных изменений. В ходе исследования подведены и описаны итоги прохождения преград. Также было замечено, что воздействие критериев для перемен связано с их построением, и я сделала вывод, что обстоятельства для перемен обязаны быть особыми для каждого.

Цель работы. Выделить и описать 7 стадий психологических барьеров для реализации изменений.

Материалы и методы. Успех - это работа, направленная наружу или внутрь, приводящая человека к нужному результату, который имеет возможность быть беспристрастно или же лично верифицирован с возможностью выделения модели работы или деятельности, которая, в будущем, приводит к удачному результату, и его воспроизведению.

Успех личности оценивается социумом исходя из присутствия или отсутствия объективного "значимого" результата (или цели) и значимости деятельности, осуществляемой в соответствии с системой общественных ценностей. Субъективная оценка результатов воспринимается человеком эмоционально как успех (удовольствие, радость и т.д.) или неудача (разочарование, обида, гнев и т.д.), но может быть реализована и испытана только в значимых видах деятельности. Существует возрастная зависимость успеха. Критерием считались еще эффективность коммуникации, отсутствие конфликтов. Предметом изучения была способность управлять личным жизненным успехом.

Была разработана концепция жизненного успеха личности и метод влияния на интеллектуальную модель жизненного выбора. Выдвинуто несколько рабочих исследовательских гипотез, некоторые из которых были подтверждены. Например, причиной успеха/ неудачи человека является интеллектуальная, многофакторная модель жизненного выбора.

В ходе анализа было определено, что программа "Успех" приводит к увеличению успеха в различных сферах жизни (от 20 до 70\%). Гипотеза о том, что трансформациями можно управлять самостоятельно через специально организованную/обнаруженную развивающую среду, дала доступ к новым исследованиям.

Было отмечено, что сначала качественных изменений в участниках не произошло, хотя этот период казался достаточным для того, чтобы окунуться в трансформацию. Но большинство участников сильно прошли первые три этапа, некоторые вошли в четвертый, но вернулись к началу. После проверки полученной информации, мотивации и готовности участников, все указывало на то, что изменения желательны, своевременны и важны для большинства участников.

Были разделены подготовительные шаги к трансформации на три части: идентификация, осознание, изменение. Важно было дать возможность увидеть, выявить противоречие, которое вызовет следующий виток развития, или отказаться, то есть что мешает человеку запустить изменения. Далее начался процесс понимания последствий для жизни, для будущего, пересмотр прошлого, а затем только трансформации.

Результаты и обсуждение. В результате всего вышесказанного были выделены 7 стадий психологических преград.

Стадии психологических преград для реализации изменений: 
"Идея". На этом этапе происходило осознание необходимости изменений, выбирается идея-модель.

"Быстрая победа". Радость понимания, активация надежды и веры в себя. Временный и недолгий рост уверенности дает веру в хороший результат изменений. Этот эффект длился для разных участников от 3 до 14 дней.

"Обвал". Попытка жить "по-новому" приводит к эмоциональному разрушению, человек убежден, что он и идея две разные вещи. И он не знает, как осуществить изменения. Без поддержки на этом этапе многие изменения прекращаются. Человек возвращается к прежнему поведению, качество жизни снижается.

"Страх". Возвращение тяги". На этом этапе для участников включался осознанный, ощутимый страх того, что эти изменения их «съедят». Многие оценили его в 100 баллов из 100. Замечено, что убеждения, привычное поведение, ценности, привычные мнения, набор стереотипов, признаются участником как "Я", а его изменение приравнивается к избавлению от "Я". То есть, наше сознание, которое делает нас людьми, в то же время лишает нас возможности легко изменяться. Многие участники говорили по поводу этого этапа: "Я понимал, что изменения возможны, но это сделает меня другим человеком, а не меня, каким-то плохим человеком и т.д.". А преобразования интерпретировались как разрушительные.

"Мотивационный уход". На этом этапе участникам казалось, что они не справляются, что изменения слишком глобальные и требуют слишком много усилий. Именно на этой стадии мотивационный уровень участников был самым низким в проекте. В то же время, участники сожалели о том, что покинули проект из-за приложенных усилий, построенных отношений и групп поддержки. Процент выполнения заданий на этом этапе был наименьшим за все время проекта.

"Осознание" Этот этап характеризовался признанием результата изменений. Участники начинали сосредотачивать свои выводы и делали небольшие шаги по следованию новой модели мышления. Результаты оставались теорией, например, "мне нужно заняться спортом", "мне нужно попробовать развить свои таланты" и так далее.

"Разрешение". Участники совершали прорыв на этом этапе, они начинали видеть причину провала, разрыв между желаемым и реальным положением дел. Они могли делить выводы на конкретные поведенческие этапы, например: "Я могу делать утренние упражнения по 15 минут каждый день; уменьшать количество порций, записываться на уроки рисования и т.д.". Они позволяли себе увидеть, как их изменения могут быть достигнуты в их конкретном случае.

Главной особенностью этого этапа было то, что участники стали искать конкретные, именно для них возможные пути улучшения ситуации.

Для удобства, назовём психологические барьеры "Долина смерти". Разрешение на решение проблемы и погружение в кризис ее осознания является ключом к успешной трансформации, и неизвестно, какими будут преобразования после прохождения Долины смерти.

Выводы. По завершению эксперимента, было выяснено, что участники Долины смерти, кроме $12,5 \%$, позволили себе войти в Долину смерти и $70 \%$ участников дошли до конца Долины смерти и получили качественные результаты.

Название "Долина смерти" появилось таким образом: одна женщина сказала: "Как будто я нырнула и не выходила на поверхность, но не кажется, что я умираю", а другая участница добавила: "А для меня это похоже на пересечение пустыни". Это пустыня из прошлого в новую жизнь". Мы вспомнили, что "Долина смерти" находится в пустыне.

Максимальный период пребывания в Долине Смерти среди участников составил 1,5 года. Отмечено, что влияние меняющей среды связано с его созданием. Участники, получив приспособленные знания о себе и прогнозы, расслаблялись, переставали действовать; 
получив ответы на свои вопросы, нашли сознательную защиту привычкам и не менялись. Принимая ответы других людей за свои стандарты, они не преодолевали трудности и не вникали в сознание. Исходя из этого сделан вывод, что условия для изменений должны быть особенными.

Также, анализируя результаты эксперимента, можно выделить пять этапов принятия изменений у участников:

Таблийа 1

Пять этапов принятия изменений

\begin{tabular}{|l|l|}
\hline Шок или отказ & $\begin{array}{l}\text { Ступор, отрицание инцидента, искреннее непринятие факта. Может } \\
\text { возникнуть эмоциональный оцепенение, возникает чувство недоверия. }\end{array}$ \\
\hline 2. Агрессия или гнев & $\begin{array}{l}\text { Признавая, что произошло, человек начинает спрашивать себя: "Почему } \\
\text { я?", "Как это могло случиться со мной?". Гнев - это способ изгнать } \\
\text { истинные чувства. }\end{array}$ \\
\hline 3. Торг & $\begin{array}{l}\text { Человек начинает торговаться, драться и пытается отложить изменения. } \\
\text { Обсудить больше привычек "прошлой жизни". Этап характеризуется } \\
\text { активным внутренним диалогом. Действия точечные, несистематические. }\end{array}$ \\
\hline 4. Депрессия & $\begin{array}{l}\text { Понимание ситуации пришло. Человек теряет сердце, испытывает полную } \\
\text { апатию, его пищевые привычки меняются (он начинает есть слишком } \\
\text { много или не ест все). Работа, которую человек обычно выполнял быстро, } \\
\text { теперь занимает в 3-4 раза больше времени. Зависимость усиливается } \\
\text { (курение, алкоголь). }\end{array}$ \\
\hline 5. Принятие & $\begin{array}{l}\text { Эта стадия не обязательно вызывает всплеск счастья; человек просто } \\
\text { занимает новую позицию. Чувства, надежды и страхи, тревога } \\
\text { воспринимаются. Появляется готовность принять ситуацию такой, какая } \\
\text { она есть. Начинается поиск решения ситуации. Новое поведение. }\end{array}$ \\
\hline
\end{tabular}

Список использованных источников:

1. Yunona Lototska (Ilina). (2012 ). «Result of scientific research: «Psychology of success»»». Abstracts of the XXX International congress of psychology. Cape Town, South Africa.

2. Yunona Lototska (Ilina) «Psychological barriers for implementation of changes». Взято c http://psytir.org.ua/index.php/technology_intellect_develop/article/view/64

3. Дж.Прохазка \& Дж. Норкросс. (2005). Системы психотерапии. Москва: Олма-пресс.

Шморгай Екатерина Олеговна, получатель высшего образования факультета компьютерной инженерии

Харьковский национальный университет радиоэлектроники, Украина

Вракина Карина Павловна, получатель высшего образования факультета компьютерной инженерии

Харьковский наџиональный университет радиоэлектроники, Украина

\section{РАЗВИТИЕ ВЗРОСЛЫХ В ВИРТУАЛЬНОМ ИНТЕЛЛЕКТУАЛЬНО-ОБРАЗОВАТЕЛЬНОМ ПРОСТРАНСТВЕ}

Неоднозначность и многоплановость современного виртуального пространства, созданного на почве Интернета, социальных и других телекоммуникационных сетей, создает серьезные вызовы для использования его в качестве учебной среды. Одной из психологических проблем здесь является сохранение развивающего потенциала и, в 
частности, обеспечение интеллектуального развития взрослых в системе дистанционного обучения.

Однако психолого-педагогические исследования развивающего потенциала виртуального образовательного пространства на сегодняшний день практически отсутствуют, а проектирование виртуальных образовательных сред и экспертных систем для развития интеллекта взрослых не исследуется вообще. Поэтому проблема исследования интеллектуального развития взрослых в виртуальном образовательном пространстве является остро актуальной как с научно-психологической, так и с социальной точки зрения. Решение этой проблемы будет способствовать интеллектуальному развитию взрослого населения страны путем внедрения информационно-коммуникационных технологий непрерывного образования в практику подготовки и переподготовки специалистов, системы повышения квалификации, социально-психологической поддержки пожилых людей и тому подобное.

Основная идея исследования состоит в том, что интеллектуальное развитие является в наше время важным условием становления и самореализации зрелой успешной личности. При реализации в исследовании проектировочного подхода в системе дистанционного образования взрослых могут быть использованы психолого-педагогические технологии развития и амплификации как текущего, так и кристаллизованного интеллекта. С помощью информационно-коммуникационных технологий создана интеллектуально-насыщенная виртуальная образовательная среда, возможности которой будут способствовать поддержке нелинейного интеллектуального развития взрослого человека с учетом соответствующей возрастной специфики.

Проведенный теоретический анализ структуры и составляющих интеллекта показали, что различные когнитивные структуры оказывают разное влияние на структуру интеллекта при интегративно-объединительной роли мышления. Мышление, речь и воображение являются ведущими когнитивными компонентами в структуре интегрированного интеллекта, поскольку их взаимодействие определяет составляющую когнитивной системы.

Существенным фактором интеллектуального развития взрослого человека является его проектная деятельность. В современных условиях интеллектуальное развитие человека возможно как в пространстве повседневного бытия, так и в специально организованных виртуальных средах. Он происходит путем обучения, результатом которого становится усвоение новых способов действий. Способ действия, в свою очередь, является системным образованием, в котором согласованы и связано знания, умения, навыки, способности и потребности субъекта действия и особенности конкретной ситуации, в которой действия должны происходить.

Обучение взрослых и обучение в виртуальных образовательных средах имеют общую важную особенность - как одно, так и другое опираются исключительно на внутреннюю мотивацию, потому субъектом обучения является именно ученик. Он самостоятельно выбирает направление обучения, определяет требования к результатам и планирует расходы, а учебную систему использует в качестве средства своего действия. Поэтому мы должны рассматривать его деятельность как, с одной стороны, собственно ученическую, а с другой - как такое управление собственной ученической деятельностью, когда ее результаты являются лишь средствами для достижения внешних результатов в более широком кругу жизнедеятельности.

Следовательно, по результатам проведенных исследований, на сегодня возможно проведение не только индивидуальной, но и групповой психологической и учебной работы в сети Интернет, в контексте использования виртуального образовательной среды, при следующих условиях: наличие специально организованного сайта; наличие технической поддержки при осуществлении групповой работы; определенный уровень компьютерной 
грамотности участников групповой работы; высокий уровень профессионализма ведущего в области практической реализации групповой работы.

В результате проведенных исследований эффективности психологических интернеттренингов, направленных на оптимизацию показателей интернет-зависимости, агрессивности, депрессивности, а также на рост показателей самоактуализации, было обнаружено, что интернет-тренинги демонстрируют свою эффективность как инновационный инструмент осуществления групповой психологической и учебной работы в сети Интернет. Все интернет-тренинги из числа исследованных показали свою высокую эффективность, тогда как интернет-тренингам, направленным на оптимизацию показателей депрессивности, была характерна средняя эффективность.

\section{Список использованных источников:}

1. Yunona Lototska (Ilina). (2012). «Result of scientific research: «Psychology of success»»». Abstracts of the XXX International congress of psychology. Cape Town, South Africa.

2. А. И. Савенков «Интеллект, ведущий к профессиональному успеху, как фактор развития профессиональной одаренности будущего специалиста»

3. Л. М. Нарикбаева «День за днем». Изъято из den-za-dnem.ru.

Ричков С.В., психолог ${ }^{2}$, студент магістратури ${ }^{1}$

${ }^{1}$ Національного університету «Острозька академія»

${ }^{2}$ Християнський центр соиіальної реабілітаџіï хворих на наркоманію та алкоголізм, Україна

Науковий керівник: Шугай Марія Анатоліївна, кандидат психологічних наук, доцент кафедри психології та педагогіки

Національний університет «Острозька академія», Украӥна

\section{РОЛЬ ЕМОЦЙНОГО ІНТЕЛЕКТУ В РЕГУЛЯЦІї ЖИТТЯ ЛЮДЕЙ 3 АДИКТИВНОЮ ПОВЕДІНКОЮ}

Адиктивна поведінка $є$ актуальною темою наукових досліджень як за кордоном: психоаналіз (А. Адлер, З. Фройд, Е. Фром), когнітивна психологія (Дж. Гріндер, Г. Олпорт), гуманістична психологія (А. Маслоу, К. Роджерс); так і серед українських науковців: (Н.Ю. Максимова [2], Н.С.Толстоухова, Н.А. Пихтіна, Г.Д. Золотова) та інші.

Про важливість цієї теми свідчить поява в XX столітті цілої галузі - адиктології. Головним питанням в цій сфері $є$ вплив тривалості адиктивної поведінки на походження та розвиток інших форм неадекватної реакції. Ось чому важливо вчасно виявити адиктивну поведінку, скоригувати та провести профілактичну роботу для попередження інших форм порушення поведінки.

Щодо терміну «емоційний інтелект», то він з'явився в кінці ХХ століття, коли П. Саловей та Дж. Майер намагалися прояснити питання рівня розвитку самоконтролю, мотивації, здатності до правильних стосунків з іншими людьми. Але лише після виходу книги Д. Гоулмана «Емоційний інтелект»[1] цей термін набув широкого розповсюдження. Він використав результати досліджень і на їх підставі довів, що успішне життя залежить не стільки від IQ, скільки від уміння керувати своїми емоціями та розуміти інших людей.

Проблема емоційного інтелекту свідчить про зростання потреби в дослідженнях, які б виявили взаємодію психічних процесів між собою та вплив цієї взаємодії на функціонування особистості. В цілому, розвиваючи здатність розрізняти та керувати своїми емоціями, людина готує себе до реалізації свого життєвого плану, формує нове 
мислення 3 урахуванням духовних потреб та матеріального благополуччя. Вплив інтелектуальних емоцій на мисленнєву діяльність виявляється через емоційне закріплення, емоційний супровід, емоційну корекцію (І.А. Васильєв, В.Л. Поплужний, О.К. Тихомиров).

Оскільки проблема регуляції та саморегуляції в сучасній психології є ключовою (Данчук Ю. П., Чеканська О.А., Пенькова О.І.)[3,4], то саме вона розкриває механізм поведінкової адаптації та внутрішніх станів людини. Ця тема має різні підходи: когнітивної регуляції (Осадько О.Ю.)[5], емоційної регуляції (Саенко Ю.В.)[6], проблеми волі (Кириленко Т.С.)[8]. Виходячи 3 вище сказаного можемо відмітити, що особливо перспективним тут $\epsilon$ дослідження внутрішніх індивідуальних ресурсів людини, а емоційний інтелект є складовою контролю поведінки (емоційна регуляція).

Мета дослідження - визначити роль емоційного інтелекту як ресурсу в регуляції життя адиктивної людини та запропонувати шляхи його розвитку в контексті християнських смисложиттєвих орієнтацій (Матласевич О.В.)[7].

Для досягнення мети дослідження передбачалося розв'язання таких завдань:

- провести системний аналіз основних моделей емоційного інтелекту та його ролі в психічній організації людини;

- визначити рівень зв'язку різних компонентів емоційного інтелекту в контексті смисложиттєвих орієнтацій;

- розробити процедуру перевірки припущення про можливість розвитку емоційного інтелекту шляхом цілеспрямованого навчального впливу;

- емпірично дослідити психологічні особливості ЕІ у адиктивних особистостей.

Для розв'язання поставлених завдань і досягнення мети дослідження було використано такі методи: теоретичні - аналіз, порівняння, систематизація даних психологічної літератури з проблем психологічних особливостей емоційного інтелекту у адиктивних особистостей (для з'ясування змісту базових понять дослідження); емпіричні для оцінки ЕІ застосовувався чотирьохмодальний емоційний опитувальник Л. Рабіновича, тест «Емоціональний інтелект» Н. Холла, шкала психологічного благополуччя К. Ріфф, для визначення стратегій подолання стресових ситуацій використана методика «Копінгповедінка в стресових ситуаціях» Н. Ендлера, тест смисложиттєвих орієнтацій (СЖО) Д. Леонтьєва. Було складено план проведення емпіричного дослідження на основі спостережень, опитування, тестування.

Дані дослідження проводилися на базі християнського центру соціальної реабілітації. В дослідженні приймало участь 25 чоловік у віці від 20 до 45 років.

Підтвердилася загальна гіпотеза про те, що психологічне благополуччя $є$ вищим, коли людина має високий рівень емоційного інтелекту. Також отримані дані дозволяють краще зрозуміти механізм формування умов для життя без вживання ПАР.

Отримані емпіричні дані, які підтверджують можливості мимовільного підвищення рівня ЕI шляхом цілеспрямованого навчання на розвиток кожної з чотирьох складових емоційного інтелекту.

Висновок: емоційний інтелект є важливим причинником регуляції життя і може бути використаний в консультаційній та психотерапевтичній практиці для вирішення як професійних так і особистісних завдань. Цей матеріал також може бути корисним і для адаптації, реабілітації та ресоціалізації осіб, які не змогли подолати важкі життєві ситуації, та як частина навчальних програм розвитку емоційного інтелекту з метою розкриття внутрішніх ресурсів людини.

\section{Список використаних джерел:}

1. Гоулман Д. Емоційний інтелект. Харків, Віват, 2018. - 511 с.

2. Максимова Н. Ю. Психологія адиктивної поведінки. //Навчальний посібник К.: Видавничо-поліграфічний центр «Київський університет», 2002. - 308 с.

3. Данчук Ю.П., Чеканська О.А. Теоретичний та експериментальний підходи до вивчення психічної регуляції і саморегуляції// Проблеми сучасної психології. - 2017. Вип. 38. - С. 146 - 155. 
4. Пенькова О.І. Проблема саморегуляції: ціннісний аспект// Науковий вісник Херсонського державного університету. Вип. 2. Том 1. 2016.

5. Осадько О.Ю. Критерії ефективності когнітивної регуляції міжособистісного спілкування// Наукові студії із соціальної та політичної психології. file:///C:/Users/PC/Desktop/Nsspp_2011_29_12\%20(2).pdf

6. Саенко Ю.В. Техники и приемы регуляции эмоций// Вопросы психологии. 2010. №3. С. 83-93.

7. Матласевич О. В. Психологічна профілактика адиктивної поведінки молоді в світлі християнського світогляду// Психологія: реальність і перспективи: збірник наукових праць Рівненського державного гуманітарного університету. Рівне РДГУ, 2013, Вип. 2

8. Кириленко Т. С. Психологія: емоційна сфера особистості// Навч. Посібник. К.: Либідь, 2007. - 336 с.

Сорохан Катерина Андріївна, здобувач вищої освіти факультету управління та економіки Хмельницький університет управління та права ім. Леоніда Юзькова, Украӥна

Науковий керівник: Шутяк Ірина Анатоліївна, старший викладач кафедри філософії, соціально-гуманітарних наук та фізичного виховання Хмельницький університет управління та права ім. Леоніда Юзькова, Украӥна

\section{РОЛЬ СПІЛКУВАННЯ У ПСИХОЛОГІЧНОМУ РОЗВИТКУ ЛЮДИНИ}

Спілкування має величезне значення у формуванні людської психіки, іiі розвитку та становленні розумного, культурного поведінки. Через спілкування 3 психологічно розвинені ми людьми, завдяки широким можливостям до навчання, людина набуває всі свої вищі пізнавальні здібності та якості. Через активне спілкування 3 розвиненими особистостями він сам перетворюється в особистість.

Соціальне становлення особистості як продукту природи і суспільства відбувається в суспільному оточенні, що зумовлює прагнення кожної людини до спілкування, основним засобом якого є мова. Дж. Дьюї акцентував увагу на тому, що первинним мотивом для мови й мовлення $є$ вплив (через вираз бажань, почуттів і думок), перш за все, на діяльність інших людей, а по-друге - на формування соціальних стосунків 3 ними [1].

Спілкування - це похідна від практичного процесу розвитку людини, iii життєдіяльності як процесу, котрий являє собою унікальний спосіб суспільного буття людини, діалектичну єдність іiі взаємодії не тільки 3 предметним світом, але й з іншими людьми». [3].

Людина народжується на світ, не маючи ні одним із властивостей, які притаманні розвиненої особистості. Всі ці властивості він набуває завдяки спілкуванню з людьми. Ті властивості особистості, які з часом проявляться у дитини, а також нові властивості особистості, які в процесі всього свого життя набуває доросла людина, спочатку притаманні людям, з якими ця дитина або цей дорослий чоловік особисто спілкуються.

Спілкування $є$ вирішальною умовою становлення кожної людини як особистості. Якщо маленьку дитину позбавити можливості спілкування з іншими людьми, то це значно затримає його психічний розвиток, а у разі дуже великих обмежень можуть статися безповоротні зміни. Про це свідчать випадки, коли діти були виховані дикими звірами. Ці діти, що потрапили згодом до людей, були цілком розвинені біологічно, але зовсім не соціалізовані. Для нормального розвитку дитини необхідний постійний контакт 3 дорослими людьми, особливо з матір'ю.

Результати спеціальних досліджень і експериментів говорять про те, що обмеження таких контактів веде до зниженого рівня розвитку пізнавальних здібностей. Вплив 
неможливості спілкування 3 іншими людьми на стан і самопочуття людини можна продемонструвати на багатьох прикладах. Спеціальні дослідження з вивчення впливу індивідуальної ізоляції на людину показують, що тривале перебування в термокамері веде, як правило, до цілого ряду порушень у сфері сприйняття, мислення, пам'яті, емоційних процесів і т.д.

Однак, серйозні порушення психічної діяльності та поведінки людини спостерігаються в умовах ізоляції тільки при відсутності цілеспрямованої діяльності і при значній гіподинамії. Цікавим і корисним матеріалом для розуміння того, як діє на людину ізоляція, є свідчення людей, добровільно або випадково опинилися в ситуації відірваності від суспільства і позбавлених міжособистісного спілкування. Це люди, які подорожують на самоті по морях і океанах, зимуючі в полярних областях, спелеологи, добровільно чи вимушено перебувають в підземних печерах, моряки, що врятувалися під час аварії корабля. Дані спостережень та спеціальних досліджень показують, що людині в цих умовах властиві такі почуття: неврівноваженість, підвищена чутливість, занепокоєння, невпевненість у собі, тривога, смуток, млявість і т.д.

Цікавим $\epsilon$ те, що всі вони в умовах ізоляції незабаром починають говорити вголос. Спочатку це свого роду коментарі побаченого чи відбувається. Потім з'являється потреба звернутися до кого-то (або чого-то). Деякі розмовляють самі з собою: підбадьорюють, віддають команди, задають питання.

Однак, серйозні порушення психічної діяльності та поведінки людини спостерігаються в умовах ізоляції тільки при відсутності цілеспрямованої діяльності і при значній гіподинамії. Для розуміння того, як діє на людину ізоляція, є свідчення людей, добровільно або випадково опинилися в ситуації відірваності від суспільства і позбавлених міжособистісного спілкування. Це люди, які подорожують на самоті по морях і океанах, зимуючі в полярних областях, спелеологи, добровільно чи вимушено перебувають в підземних печерах, моряки, що врятувалися під час аварії корабля. Дані спостережень та спеціальних досліджень показують, що людині в цих умовах властиві такі почуття: неврівноваженість, підвищена чутливість, занепокоєння, невпевненість у собі, тривога, смуток, млявість і т.д.

Якщо людина відчуває дефіцит спілкування з іншими людьми, у нього не можуть у достатній мірі розвинутися комунікативні навички та вміння. У кращому випадку, дана людина буде володіти деяким порівняно примітивним набором невербальних засобів спілкування, які передаються у спадок. При цьому у нього не буде вербальних засобів спілкування, пов'язаних з людською культурою, а так само вербальних засобів спілкування, пов'язаних зі знанням і використанням мови.

Що стосується слабкого розвитку інтелекту, то воно виступає як результат дефіциту спілкування людини 3 людьми 3 таких причин. По-перше, внаслідок слабкого розвитку мови, по-друге, через те, що людина позбавляється можливості навчатися на прикладі інших людей, з більш розвиненим, ніж у нього самого, інтелектом. На початку свого розвитку діти, граючи разом з іншими дітьми або людьми або займаючись разом з ними будь-якими справами, вирішують спільно, у безпосередньому спілкуванні різноманітні завдання.

Дорослі люди і більш досвідчені партнери по спільній діяльності демонструють дитині способи вирішення завдань, пояснюють їх і допомагають оволодіти ними. Дитина розвиває свій інтелект не тільки наслідуючи іншим людям, але і під їх керівництвом, що виключено, у разі відсутності активного спілкування. Приблизно те ж саме характеризує і інтелектуальний розвиток дорослих людей

Діяльність людини, іiі спілкування 3 іншими взаємопов'язані й відокремлено існувати не можуть. Будь-який різновид людської діяльності реалізуються через 
спілкування, а спілкування - через них. Підкреслимо про спілкування з собою, коли людина подумки продовжує розмову [2].

Взаємозв'язок особистості з соціумом реалізується через систему відносин індивіда і суспільства. Людина вступає в різні відносини - соціальні (відображають взаємодію соціальних груп та індивідів як їх представників), суспільні (характеризують взаємодію особи через соціальні спільноти з суспільством), міжособистісні (безпосередня чи опосередкована взаємодія людей, яка

\section{Висновки.}

Отже, спілкування - це складний і багатогранний процес. У спілкуванні людина формується і самовизначається, виявляючи свої індивідуальні особливості. Спілкування координує спільні дії людей і задовольняє потребу в психологічному контакті. Функціональні можливості спілкування залежать від особливостей соціальнопсихологічного середовища, мети взаємодії.

\section{Список використаних джерел:}

1. Дьюи Дж. Психология и педагогика мышления. М. : Лабиринт, 1999. - 192 с.

2. Орбан-Лембрик Л. Е. Соціальна психологія : Посіб.- К. : Академвидав, 2003. - 448 с.

3. Ситниченко Л.А. Першоджерела комунікативної філософії.- К. : Либідь: 1996. - 176с.

\section{Меняйлова Марія Ігорівна}

Одеський національний медичний університет, Украӥна

Науковий керівник: Фучерджи Весна Дмитрівна, к.ю.н., доцент

Одеський національний медичний університет, Україна

\section{СХИЛЬНІСТЬ ДО МАНІПУЛЯЦІЇ У СПІЛКУВАННІ СЕРЕД МОЛОДІ}

Незважаючи на надзвичайно широке поширення маніпуляції в сучасному житті i, як наслідок, величезний інтерес до питань, пов'язаних з її проявом, спонукальними мотивами, механізмами і засобами здійснення, ця широка сфера людських взаємин залишається багато в чому неясною, i, найголовніше, практично не піддається виміру.

У зв'язку з цим досить актуальним $є$ вивчення тенденції маніпулювати іншими з точки зору ступеня вираженості макіавеллістічності особистості або рівня макіавеллізму. Зміни у суспільстві сприяли загостренню міжособистісних відносин і зростанню уваги до проблем маніпуляції, використання маніпулятивних прийомів і різних способів протидії іншим суб'єктам [5]. Вимірювання рівня макіавеллізму дозволяє визначити ступінь готовності однієї людини 3 вираженими макіавеллівськими схильностями використовувати i експлуатувати іншого 3 низьким рівнем макіавеллізму, готового за цілою низкою особистісних характеристик підкоритися і бути експлуатованим.

Найголовніша мета нашої роботі полягае в тому, чтоб виявити взаємозв'язки між типом темпераменту, стратегію поведінки в конфліктній ситуації, характеристиками особистості та рівнем макіавеллізму особистості.

Проаналізувавши літературу ми можемо сказати, що спілкування - неодмінний елемент людського життя. Спілкування пронизує наше життя на багатьох різних рівнях (мотиваційному, біологічному, соціальному, діяльністному, тощо) [1]. Для деяких людей спілкування, із засобу, стає саме метою. Для задоволення потреби у спілкуванні використовуються такі функції як: амотивна, спонукальна, інформаційна, тощо.

Маніпуляція - це приховане спонукання іншої людини до дії, яку адресат маніпуляції 
стає вважати за своє власне рішення. Макіавеллізм - це експлуататорська установка по відношенню до інших, для досягнення своїх цілей.

За результатами дослідження ми виявили наступне: середній рівень маніпулятивності у жінок вищий, ніж у чоловіків, хоча все ще відповідає низькому рівню макіавеллізму.

Також ми виявили кореляцію між низьким рівнем макіавеллізму та високими результатами по шкалам Товариськості (відкритість, природність, невимушеність, готовність до співпраці, пристосовність, увагу до людей, готовність до спільної роботи, активність в усуненні конфліктів в групі, готовність йти на поводу. Легкість у встановленні безпосередніх, міжособистісних контактів) та Дипломатичності (вишуканість, вміння вести себе в суспільстві, в спілкуванні дипломатичність, емоційна витриманість, проникливість, обережність, хитрість, естетична витонченість, іноді ненадійність, вміння знаходити вихід зі складних ситуацій, розважливість.). В випадку з середнім рівнем макіавеллізму залежності між шкалами не спостерігається.

Так, провівши дослідження ми не можемо 3 певність казати про те, що існує залежність між певними рисами характеру людини та вираженістю макіавеллістичних рис характеру у людей 20-23 років, які потрапили до нашої вибірки.

\section{Список використаних джерел:}

1. Ільїн Є.П. Психологія спілкування і міжособистісних відносин/ Є.П. Ільїн // СПб .: Пітер -2009.

2. Капцов О.В. Взаємозв'язок макіавеллізму та особистісних цінностей молодих менеджерів/ О.В. Капцов // Соціальна психологія сьогодні: наука і практика// СПбГУП - 2006.

3. Катунін Д. Б. Макіавеллізм як психологічна проблема: історія питання/ Д. Б. Катунін, Л. В. Куліков // Вісник Санкт-Петербурзького університету - Серія 6 - «Політологія. Міжнародні відносини» - Вип.2 2006 - C.68-79.

4. Свербіхіна А. Г. Особливості міжособистісних відносин у студентів з різним рівнем макіавеллізма/ А. Г. Свербіхіна // Психологія і педагогіка: методика та проблеми практичного застосування - Вип. 31 - 2013 C.54-58.

5. Щербовіч В.А. Дослідження впливу маніпулятивної спрямованості особистості в спілкуванні на ії соціометричний статус в групі/ В.А. Щербовіч // Вісник Адигейського державного університету - Вип.4 2005 - C.199-200.

Штангрет Лілія Іванівна, здобувач вищої освіти ННІ педагогічної освіти, соціальної роботи і мистецтва Черкаський національний університет імені Богдана Хмельницького, Украйна

Науковий керівник: Коломісць Олена Германівна, докт. філ наук, професор кафедри соціальної роботи та соціальної педагогіки

Черкаський національний університет імені Богдана Хмельниџького, Украӥна

\section{ТЕХНОЛОГІЯ СТВОРЕННЯ ШКІЛЬНОЇ СЛУЖБИ ПОРОЗУМІННЯ "СОNТАСТ" В ГЕРОНИМІВСЬКОМУ ЗАКЛАДІ ЗАГАЛЬНОЇ СЕРЕДНЬОЇ ОСВІТИ І-ІІ СТУПЕНІВ}

На даному етапі розвитку та розбудови мирного середовища в Україні безперечним ефективним способом вирішення конфліктів $є$ медіація, яка виступає інструментом відновного підходу, який поєднує цінності, принципи, практики і методи вирішення конфліктів.

Саме ціннісний підхід став поштовхом до запровадження ГО «ЛА Страда-Україна» медіації в закладах освіти України в 2015 році. Період навчання для дітей і молоді - це 
період, коли формуються ті самі цінності, що створюють свідомість людини, і які вона буде нести скрізь все своє життя. Формування таких цінностей як толерантність, повага, підтримка, порядність тощо - $є$ запорукою для навчання молоді життєво важливої стратегії гармонійного спілкування та співіснування у суспільстві. Під впливом конфлікту і медіації цей набір цінностей підтверджуєтья і затверджується, що в свою чергу допомагає освіті досягти своєї мети - виховати гідну особистість зі стійкими навичками ненасильницької поведінки та прагненням створювати мирні стратегії поведінки в суспільстві [1].

Формування мирного взаємовідношення та взаємоповаги в закладах освіти, коли поруч з цим набирають обертів, такі явища, як шкільний булінг, кібербулінг є одним із передових шляхів до попередження їх виникнення.

На нашу думку, вирішення конфліктів в шкільному середовищі у ХХІ столітті - це впровадження шкільної служби порозуміння, яка не просто допоможе учням розв'язувати будь-які конфлікти, але й закріпить в учнів Skills відважного, ініціативного, активного, толерантного реформатора соціуму, який будує мирне середовище не десь там в зошиті чи правилі, а прямо тут і зараз, починаючи з себе та своїх вчинків. Досліджуючи проблему булінгу в шкільному середовищі, працюючи над соціальної реабілітацією жертв шкільного булінгу, ми вирішили зосередити свою увагу на попередженні цього явища, оскільки вважаємо, що варто працювати над вихованням безконфліктного покоління, учнів, які будуть поважати один одного, вільно висловлювати позиції та думки, не боятися бути індивідуальністю, а в разі виникнення певних суперечностей знати про шляхи їх розв'язання за допомогою шкільної служби порозуміння "Contact”, яку ми запровадили у Геронимівському закладі загальної середньої освіти I-III ступенів, оскільки вважаємо, що інноваційним способом для вирішення конфліктності в шкільному середовищі є створення шкільної служби порозуміння.

В закладі загальної середньої освіти с. Геронимівка було виявлено високий рівень конфліктності. Причинами якого ми виділяємо: замовчування конфліктів; відсутність технології мирного вирішення конфліктів; неспівпадання поглядів та інтересів учнів; особливості темпераментів та характерів учнів; самооцінка, стилі виховання учнів; матеріальний стан сім'ї; незосередженість соціальних педагогів та класних керівників на особистісних та міжособистісних проблемах учнів; низький рівень поінформованості учнів про "природу" конфліктів; відсутність єдиного встановленого механізму вирішення конфлікту між учнями.

Задля уникнення наслідків, якими є: виникнення різноманітних конфліктів між учнями; безвихідне положення учнів під час виникнення конфлікту, оскільки вони не знають як правильно його вирішити; загострення конфлікту, яке може перерости в булінг ми прагнули створити шкільний простір для вирішення конфліктів за допомогою впровадження шкільної служби порозуміння "Contact".

Ідея нашого проекту полягала у створенні шкільної служби порозуміння “Contact” в закладі загальної середньої освіти с. Геронимівка. Оскільки в даному закладі не існує визначеного механізму для вирішення конфліктів мирним шляхом за принципом «рівнийрівному/рівна-рівній», вважаємо, що шкільна служба порозуміння сприяє зменшенню загального рівня конфліктності в освітньому середовищі, навчить учнів правильно ставитися до конфліктів та вирішувати їх, а також буде простором для реалізації та усвідомлення значущості учнів в шкільному закладі, їх важливості для нього та самореалізації, адже саме вони виступатимуть медіаторами. На нашу думку, саме включеність учнів у вирішення конфліктів за допомогою медіації сприятиме запобіганню шкільного булінгу та інших негативних явищ.

Таким чином ми працюємо шляхом навчання медіаторів/медіаторок 3 числа учнів/учениць Геронимівського закладу загальної середньої освіти I-III ступенів та 
плануємо організувати моніторингову діяльність щодо отримання контрольного зрізу результатів діяльності шкільної служби порозуміння “Contact”.

\section{Список використаних джерел:}

1. Андрєєнкова В.Л., Гайдук В.І., Лунченко Н.В., Матвійчук М.М., Харьківська Т.А., Чернець К.О. Створення системи служб порозуміння для впровадження медіації за принципом «рівний-рівному/рівнарівній» та вирішення конфліктів мирним шляхом у закладах освіти. Київ: ФОП НІчого С.О. 2018. 174 с. 
МАТЕРІАЛИ МІЖНАРОДНОЇ
СТУДЕНТСЬКОЇ НАУКОВОЇ КОНФЕРЕНЦІЇ

\title{
«МОДЕРНІЗАЦІЯ ТА СУЧАСНІ УКРАЇНСЬКІ ТА СВІТОВІ НАУКОВІ ДОСЛІДЖЕННЯ»
}

\author{
29 травня 2020 року Львів, Україна
}

\section{TOM 2}

Українською, російською та англійською мовами

Всі матеріали пройшли оглядове рецензування

Організаційний комітет не завжди поділяє позицію авторів

За точність викладеного матеріалу відповідальність несуть автори

Підписано до друку 29.05.2020. Формат 60×84/16.

Папір офсетний. Гарнітура Arial. Цифровий друк.

Умовно-друк. арк. 6,51.

Тираж: 100 примірників.

Віддруковано з готового оригінал-макету.

Контактна інформація організаційного комітету:

21037, Україна, м. Вінниця, вул. Зодчих, 40, офріс 103

Молодіжна наукова ліга

Телесони: +38098 1948380; +380981956755

E-mail: liga@ukrlogos.in.ua

www.ukrlogos.in.ua| www.ojs.ukrlogos.in.ua

Видавець друкованих матеріалів: Друкарня ФОП Гуляєва В.М.

08700, Україна, м. Обухів, вул. Малишка, 5. E-mail: 5894939@gmail.com

Свідоцтво суб’єкта видавничої справи: ДК № 3909 від 02.11.2010 р. 